DNB Working Paper

No. 569 / September 2017

Herding behaviour of Dutch pension funds in sovereign bond investments

Ian Koetsier and Jacob Bikker

DeNederlandscheBank

EUROSYSTEEM 


\section{Herding behaviour of Dutch pension funds in sovereign bond investments}

Ian Koetsier and Jacob Bikker*

* Views expressed are those of the authors and do not necessarily reflect official positions of De Nederlandsche Bank.

Working Paper No. 569

September 2017
De Nederlandsche Bank NV

P.O. Box 98

$1000 \mathrm{AB}$ AMSTERDAM

The Netherlands 


\title{
Herding behaviour of Dutch pension funds in sovereign bond investments*
}

\author{
Ian Koetsier ${ }^{\mathrm{a}}$ and Jacob Bikker ${ }^{\mathrm{b}}$ \\ ${ }^{a}$ Utrecht University \\ ${ }^{\mathrm{b}}$ De Nederlandsche Bank and Utrecht University
}

11 September 2017

\begin{abstract}
This study investigates herding behaviour exhibited by Dutch pension funds in the sovereign bond market. It uses a unique dataset on sovereign bond holdings of pension funds, mutations and transactions between December 2008 and December 2014. It covers 67 large Dutch pension funds that invest in 109 countries. We find evidence of intensive herding behaviour of Dutch pension funds in sovereign bonds. Our findings also show that institutional factors, the macroeconomic environment and the financial market environment are among the determinants of herding behaviour in sovereign bonds. Our results also indicate that high diversification is not without costs as it intensifies herding behaviour. We find mixed evidence on whether pension funds are stabilising actors. The destabilising effect is most pronounced on the sell side, while stabilisation is most prominent under more extreme price shocks. The distinction between developing and emerging economies and developed economies does not change these results.
\end{abstract}

Keywords: Herd behaviour, stabilising, destabilising, pension funds, sovereign bonds.

JEL classifications: G11, G15, G18, G23.

\footnotetext{
* Corresponding author: Ian Koetsier, Utrecht University, Utrecht School of Economics, Adam Smith Hall, Kriekenpitplein 21-22, 3584 EC Utrecht, The Netherlands; i.koetsier@uu.nl.

The views expressed here are solely those of the authors and do not in any way represent the views of the institutions to which they are affiliated.
} 


\section{Introduction}

Government debt has grown substantially in most advanced economies over the past decade, and not without consequences. Government debt took centre stage in the European debt crisis. Greece, Portugal and Cyprus were given bail-out support, while financial markets in Italy and Spain came under increasing pressure. Most studies focus on the size of government debt (e.g. Reinhart and Rogoff, 2009; Baum et al., 2013), while behaviour on the demand side of government debt has remained largely uninvestigated. With respect to developing countries, it is often argued that international institutional investors contribute to destabilisation of financial markets in times of crisis (Kaminsky 2000; Kaminsky et al. 2004; Kim and Lee, 2014). In some cases, crises even spread between countries that do not appear to have any economic fundamentals in common (Goldstein and Pauzner, 2004).

Institutional investors manage a substantial part of global financial assets. Accordingly, their behaviour is likely to have a significant impact on financial market sentiment (De Haan and Kakes, 2010). Their herding behaviour is believed to undermine financial stability. Herding behaviour occurs when investors imitate the investments of other market participants without using their own information. Herding by institutional investors may move securities away from their price equilibrium and induce abnormal volatility (Chang et al., 2000). Whether this occurs in practice remains a subject of heated debate, both in academic and in policy circles. Institutional investors are often considered long-term investors trading on fundamentals. This type of investment behaviour has a stabilising effect on financial markets. In itself, the occurrence of herding is not necessarily destabilising. Therefore, this study investigates whether intensive periods of herding behaviour are followed by return reversals.

Only a small number of herding studies focus on pension funds, although pension funds represent a considerable proportion of the group of institutional investors. Furthermore, they will gain importance over time due to the ageing population, and their trading behaviour consequently warrants more attention. However, previous studies have mainly focused on herding behaviour of mutual funds or institutional investors as a group in the United States. This could be problematic because the behaviour of the entire group of institutional investors could blur the trading behaviour of pension funds.

We are particularly interested in the time of the European sovereign debt crisis. In times of crisis, the stabilising function of pension fund investments is needed most from the perspective of public welfare. Christie and Huang (1995) note, however, that herding behaviour intensifies under extreme market circumstances. Bengtsson (2013, p.4) even states that "it is also widely recognized that institutional investors can contribute to systemic risk by making asset prices stray away from fundamentals, and fuelling financial bubbles and pro-cyclicality through herding behaviour." If this is a consequence of 
pension fund herding behaviour, it is especially worrisome because pension fund investments also have a social function as they contribute to the built-up of old-age income.

We focus on long-term sovereign bonds. These bonds comprise $99 \%$ of sovereign investments and they are believed to be more stable than equity investments. This asset class should therefore potentially lead to underestimation of herd behaviour. We define a long-term bond as a bond with a maturity period of at least one year. To our knowledge, we are the first to investigate the herding behaviour of pension funds in long-term sovereign debt investments. Our main aim is to establish whether pension funds exhibit herd behaviour in long-term sovereign debt investments. We will also look at the drivers of such herd behaviour. Moreover, this study provides evidence on the question of whether pension funds' herding behaviour has a stabilising or destabilising effect.

We use two unique datasets provided by De Nederlandsche Bank (DNB), the Dutch central bank. We combine balance of payments statistics with pension fund-specific characteristics. The data on pension fund holdings breaks down into sales and purchases, revaluations, exchange rate adjustments and other adjustments. This is a rich data set which is not available is most other herding studies, which encounter typical problems, such as estimating the purchases and sales in a period using pension fund or mutual fund holdings and index returns. ${ }^{3} \mathrm{We}$ elect to focus on long-term sovereign debt (one year or more) because of its significance in pension funds' investment portfolios. Long-term sovereign debt holdings grew to EUR 164 billion in December 2014 from EUR 89 billion in December 2008. These holdings represent the largest proportion of sovereign holdings. On average, long-term sovereign debt holdings account for $98.8 \%$ of all direct sovereign holdings of Dutch pension funds. Assessing these holdings will therefore provide us with a comprehensive view how Dutch pension funds behaved during the European sovereign debt crisis.

Our study contributes to the literature in several ways. First, there are different studies that focus on herding in equity investments by mutual funds (Choe et al., 1999; Borensztein and Gelos 2000; Kaminsky et al. 2004; Kim and Lee, 2014). To our knowledge, this is the first attempt to investigate pension funds' herding in sovereign bonds on an international scale. ${ }^{4}$ Second, from a public welfare perspective, the stabilising or destabilising behaviour of pension funds is most important in times of crisis. Despite several prior studies, however, little is known about how international institutional investors trade around the world and how their trading strategies differ in tranquil and crisis times ${ }^{5}$ (Kim and Lee, 2014). This study investigates herding behaviour during the European sovereign debt crisis. Third, we have a

\footnotetext{
${ }^{3}$ Numerous studies calculate the buying and selling behaviour over a specific time frame by investigating the end-ofperiod holdings and the overall market returns.

${ }^{4}$ Raddatz and Schmukler (2013) only use domestic government bonds.

${ }^{5}$ These studies often have a very low data frequency. Our study uses monthly data.
} 
unique micro-dataset of Dutch pension funds on a monthly basis at our disposal, which allows us to analyse long-term sovereign bonds trading in 109 countries. Fourth, this study may contribute to the development of regulatory policies as it improves the understanding that policymakers have of the trading behaviour of pension funds. Mispricing resulting from this trading behaviour reduces the effectiveness of the market mechanism to reveal the 'fair value' of assets, undermining the fundamental principle of market efficiency (Devenow and Welch, 1996).

Our paper is structured as follows. Section 2 reviews the literature. Section 3 explores the Dutch pension system. Section 4 explains the methodology and data used. Section 5 presents our results and Section 6 includes our conclusions.

\section{Literature review}

Herding in financial markets occurs when market participants contemporaneously trade in the same direction and/or their behaviour converges to the market consensus (Galariotis et al., 2015). This happens over a specific period, known as the herd interval. Herding is an indication that financial markets are not always efficient. Evidently, traditional asset pricing models with rational actors have no room for mimic behaviour of investors or convergence towards the market consensus. This study examines herding at the micro-level of pension funds (contemporaneously trading in the same direction). As a consequence of herding, asset prices may not reflect fundamental values. ${ }^{6}$

There are four main rational herding models that explain why herding behaviour may occur: characteristic; reputational; informational, and investigative herding. ${ }^{7}$ Characteristics herding has two components: the asset and the investor. Investors trade based on the specific characteristics of an asset (Falkenstein, 1996; Bennett et al., 2003; Holmes et al., 2013). This study defines momentum trading as a form of characteristic herding because investors chase past returns (which is an asset characteristic). Furthermore, asset managers have similar characteristics (e.g. their education and their social environment and/or background). Consequently, they may interpret information or signals similarly. Reputational considerations are also believed to be a driver of herding behaviour. Asset managers stay close to the pack because underperformance may adversely impact their remuneration or their career prospects (Scharfstein

\footnotetext{
${ }^{6}$ Herd behaviour may be efficient if herding is based on fundamentals (e.g. new macroeconomic information). Bikhchandani and Sharma (2000) note that there are two forms of herding. Spurious herding occurs when participants react in a similar way to new information. Intentional herding occurs when participants copy one another intentionally. Thus, spurious herding may improve the efficiency of the financial markets by a quicker incorporation of new information in asset prices. Following Holmes et al. (2013), we will give some intuitive evidence on the occurrence of spurious and intentional herding using the market circumstances.

${ }^{7}$ We have only included rational herding models. The rational models are suitable for pension funds. They are less prone to crazes and psychological biases than retail investors are.
} 
and Stein, 1990; Rajan, 2006). Another theoretical reason for the occurrence of herding is some managers' superior ability. Thus, other managers will follow their high ability counterparts (e.g. guru investors) (Trueman, 1994). If this is the case, investors engage in informational herding. They try to infer information from other investors' trades (Bikhchandani et al., 1992; Banerjee 1992; Sias, 2004). Investigative herding is closely related to informational herding. In investigative herding, market participants act on the same signals, for instance, credit rating changes and/or Bloomberg data (Froot $e t$ al., 1992; Hirshleifer et al., 1994), rather than inferring information from other market participants' trades. ${ }^{8,9}$

We are particularly interested in investment behaviour in times of crisis. If herding is aggravated during crises, this may cause high societal costs. ${ }^{10}$ Most studies on herding behaviour during crises focus on emerging economies in Asia and Latin America. In addition, the scientific literature mainly uses data on mutual funds which is easier to come by than data on pension funds, and mutual funds mainly engage in equity investments. For example, Kaminsky et al. (2004) use data from 13 Latin American equity funds between April 1993 and January 1999. They demonstrate that mutual fund managers and investors engage in momentum trading. ${ }^{11}$ Momentum trading behaviour is aggravated during crises. Managers and investors also practice contagion trading - they sell (buy) assets from one country when asset prices fall (rise) in another (Kaminsky et al., 2004).

Several studies focus on the effects of the Asian crisis and the consequences of herding behaviour. In their study on the Korean stock market, Choe et al. (1999) distinguish between foreign and domestic investors. They find that foreign investors engage in positive feedback trading and herding, contrary to domestic investors. However, they do not find convincing evidence of herding behaviour during the Asian crisis. ${ }^{12}$ The findings of Hwang and Salmon (2004) also point in this direction. Their findings reveal that the US and the Korean stock markets herd towards market consensus, disregarding market conditions and macroeconomic factors. The Asian crisis and the Russian crisis reduce herding and are clearly identified as turning points in herding behaviour (Hwang and Salmon, 2004). In contrast, Kim and Wei (2002) find herding and positive feedback trading for Korea at the time of the crisis. ${ }^{13}$ In a more recent study, Hsieh $e t$

\footnotetext{
${ }^{8}$ Note that the theoretical reasons are not mutually exclusive.

${ }^{9}$ Rational herding is often linked to the occurrence of 'pure' contagion in theoretical contributions. For example, Calvo and Mendoza (2000) note that fixed costs for gathering and analysing country-specific information can lead to herd behaviour. An extensive investigation into 'pure' contagion is beyond the scope of this paper because we focus on the occurrence and causes of herd behaviour and contagion will be accounted for in the co-movement of financial market and macroeconomic sentiments.

${ }^{10}$ Koetsier and Bikker (2017) provide an extensive review of the empirical literature on herding behaviour.

${ }^{11}$ This study targets momentum trading a form of herd behaviour. Mutual funds follow previous returns, which is a form of characteristic herding.

${ }^{12}$ Their study covers the period from 30 November 1996 to 1997 year-end.

${ }^{13}$ Kim and Wei (2002) cover a slightly longer period (December 1996 to June 1998) than Choe et al. (1999).
} 
al. (2011) investigate herding in 12 Asian markets ${ }^{14}$ between 1996 and 2004. They find that the positive feedback effect and herding occur in the Asian markets. Moreover, positive feedback trading and herding is more pronounced in countries during and after a crisis.

Numerous studies investigate herding for emerging economies in multiple regions, among them, Borensztein and Gelos (2000) and Gelos and Wei (2005). Borensztein and Gelos (2000) use between 382 and 467 equity funds between January 1996 and March 1999. These funds were invested in Asia, Latin America, Europe, the Middle East and Africa. They find that herding behaviour exists, although to a relatively modest extent. Interestingly enough, they find no significant difference between the prevalence of herding in crisis and in tranquil times. An additional contribution is that open-ended funds engage more aggressively in herding than closed-end funds. ${ }^{15}$ In another study, Gelos and Wei (2005) investigate 137 global emerging market and international equity funds. They focus on the effect of transparency on the behaviour of mutual funds. Their main finding is that herding is more likely to occur in less transparent countries. Moreover, funds have a greater propensity to exit non-transparent countries during crises (Gelos and Wei, 2005). This indicates that herding during crises may be related to a country's transparency.

Recent studies try to explain the seemingly contradictory results on herding behaviour during crisis periods. Kim and Lee (2014) investigate the behaviour of 292 institutional investors in the equity market. ${ }^{16}$ They find that herding behaviour is potentially time inconsistent. Before the 2007-2008 financial crisis, they find strong evidence of short-term momentum trading at the level of individual stock and at the market level. However, during the crisis, medium-term momentum trading increases compared to tranquil times, whereas short-term momentum trading decreases. Galariotis et al. (2015) investigates herding behaviour in the United States and the United Kingdom on days when macroeconomic data became available. For the United States, they find that investors herd based on both fundamentals and nonfundamentals during crises (Galariotis et al., 2015). Their findings for the United Kingdom show a very different behavioural pattern. Herding was only observed during the Dot.com crisis and was based on fundamentals only. Economou et al. (2011) also present evidence on possible country-specific effects. They investigate the Portuguese, Italian, Greek and Spanish stock markets between 1998 and 2008, and observed herding behaviour in the Greek and Italian markets. There is some mixed evidence for the

\footnotetext{
${ }^{14}$ Bangladesh, China, Hong Kong, India, Indonesia, Korea, Malaysia, Philippines, Singapore, Sri Lanka, Taiwan and Thailand.

${ }^{15}$ Dutch pension funds are closed-end funds by law, so we are unable to distinguish between open and closed-end funds.

${ }^{16}$ The institutional investors reside in 21 developed markets: Australia, Austria, Belgium, Canada, Denmark, Finland, France, Germany, Greece, Hong Kong, Italy, Japan, the Netherlands, New Zealand, Norway, Portugal, Singapore, Spain, Sweden, Switzerland, and the United Kingdom - and 15 emerging markets: Brazil, Chile, China, India, Indonesia, Israel, Korea, Malaysia, Mexico, the Philippines, Poland, South Africa, Taiwan, Thailand, and Turkey (Kim and Lee, 2014).
} 
Portuguese market. These findings suggest that herding may be time-inconsistent, and its extent and occurrence potentially differ between advanced economies.

These studies focus on equity investments only, but our study investigates herding in long-term sovereign bonds. There are few studies on herd behaviour for bond investments, which mostly use data of mutual bond funds. There are some guarded indications that herding behaviour in bond investments is potentially more pronounced than in equity investments. Cai et al. (2012) find that corporate bond herding measure is 0.15 on average for US bond funds, meaning that $65 \%$ of trades go in one direction and $35 \%$ in the other direction. This is considerably more than the herding measure for equity trades. These measures are often close to 0.03 for equity investments in the United States. More recently, Xiao (2015) uses data of foreign and domestic equity and bond mutual funds for Mexico. ${ }^{17}$ This enabled her to distinguish between domestic and foreign investors. Her findings show that foreign funds herd more intensively during periods of market stress. The herding measure is about $70 \%$ higher for foreign bond funds than during tranquil times. There is also considerable heterogeneity between the types of funds. Bond funds prove to be more sensitive to global factors and they engage more aggressively in positive feedback trading than equity funds do. These findings show that bond investors could potentially be more prone to herding behaviour than equity investors. Broeders et al. (2016) examine types of herd behaviour by Dutch pension funds for equities and bonds. They also find support for the information, regulation and reputation motives of herding behaviour for bonds.

Whether the previous findings can be extended to sovereign bond investors remains to be seen. There are only a very limited number of studies that focus on herding behaviour in sovereign bond holdings. Xiao (2007) investigates the behaviour of emerging market mutual funds that specialise in sovereign bonds. Her dataset includes 44 bond funds between May 2003 and December 2003. The investments of these funds are directed towards emerging markets. Xiao finds evidence of momentum trading by these funds as they chase bonds with high past returns and yields. ${ }^{18}$ Raddatz and Schmukler (2013) examine herding behaviour for multiple asset classes, including domestic corporate bonds, domestic financial institution bonds, domestic government bonds and domestic mortgage bonds. Their monthly data covers the period between 1996 and 2005, and their findings clearly show that herding behaviour differs considerably between asset classes. On average, they find a herding measure for domestic government bonds of around 0.01 . However, the use of domestic bonds may lead to underestimation of herding behaviour in sovereign bonds, due to information advantages for domestic bond investments. ${ }^{19}$

\footnotetext{
${ }^{17}$ She groups sovereign and corporate bonds together.

18 The different bonds are denominated in US dollars.

${ }^{19}$ This study focuses on all long-term sovereign bond holdings of Dutch pension funds, which include investments in 109 countries.
} 
In summary, earlier studies find mixed evidence on the occurrence and extent of herding behaviour during crises. Herding behaviour is sometimes linked to the investor's country of residence. There are some indications that herding behaviour is partly time and country specific. Most studies focus on equity markets which may bias the results and the debate on herding behaviour. Bond investments are also a sizeable asset class, particularly for pension funds. Furthermore, these studies mainly investigate the behaviour of mutual funds, which is only one type of institutional investor. More research is needed to derive a clear conclusion about herding behaviour in the sovereign bond market. Our study on pension funds' herding behaviour in the sovereign bond market endeavours to fill this gap in the empirical literature.

\section{The Dutch pension system}

The Dutch pension system is a three-pillar system. ${ }^{20}$ We will focus on the second pillar, which consists of company-specific and sector-specific pension funds that invest employee and employer contributions upfront. Their holdings accumulate over time and form part of their members' retirement income. The second pillar grows over time and on average comprises about half of a retired person's income. This is considerably more than in most other advanced economies.

The holdings of all second pillar pension funds came to EUR 1,220 billion at the end of 2014. ${ }^{21}$ This represents $191 \%$ of Dutch GDP in that year. Their size results from the construction of the second pillar, which is officially quasi-mandatory. However, in practice, over $91 \%$ of the active labour force participates in the second pillar. The Minister of Social Affairs and Employment plays a key role as she can declare a collective bargaining agreement binding. The result of such a decision is that pension arrangements embedded in the agreement become binding for the entire sector. Ultimately, this leads to mandatory participation in the second pillar by employers and employees. Another reason for its size is that there is no opt-out option. Dutch pension funds are closed-end funds for their members. These aspects combined with the long tradition of the second pillar result in large pension funds holdings compared to other countries.

Pension fund investments are relatively unrestricted relative to other countries. This is attributable to the Dutch regulation framework, which is based on the prudent person rule. Article 135 of the Dutch Pensions Act states that a pension fund's investments must be in the best interests of active and former members and pensioners. The Dutch Pensions Act includes only one explicit restriction on investments:

\footnotetext{
${ }^{20}$ Koetsier and Bikker (2017) provide a more detailed explanation of the Dutch pensions system.

${ }^{21}$ Data retrieved from De Nederlandsche Bank (2015), Macroeconomic statistics pension funds.

22 The number is retrieved from a study by Van der Smitte (2013). 
investments of company and sector funds are limited to their own company or group of companies.

However, the law explicitly states that these limitations do not apply to sovereign bond holdings, meaning that Dutch pension funds are essentially free to invest in sovereign bonds. Their investment behaviour gives a clear indication of their preference for these assets. Moreover, the absence of legal restrictions gives them the opportunity to exhibit herding behaviour without any a priori influence of legal restrictions on their investment decisions. ${ }^{23}$

\section{Methodology and data}

\subsection{Methodology}

To assess herding behaviour and its causes, we will first estimate the herding measure introduced by Lakonishok et al. (1992) (LSV). Second, we will employ this herding measure as our dependent variable in the regression analysis.

The LSV herding measure is widely used in the herding literature (e.g. Grinblatt et al., 1995; Voronkova and Bohl, 2005; Cai et al., 2012). The measure represents the balance or imbalance between the buys and sells in an asset class or country over a specific period. It includes an adjustment factor for the expected imbalance between buys and sells which simply occur by random chance. Thus, herding occurs when there is more trading in a specific direction then you would expect if trading is random and independent. ${ }^{24}$ We agree with the International Monetary Fund (2014) that the measure provides indicative evidence of 'true' herding. ${ }^{25}$

Following the LSV, we define the herding measure as:

$$
H M_{i t}=\left|p_{i t}-p_{t}\right|-A F_{i t}
$$

Where

$$
p_{i t}=\frac{B_{i t}}{B_{i t}+S_{i t}}
$$

and

$$
p_{t}=\frac{\sum_{i=1}^{n} p_{i t}}{n}
$$

\footnotetext{
${ }^{23}$ The observed herding behaviour is not the result of investment restrictions by the government or the pension funds' supervisor. For example, there may be restrictions on in which countries to invest, or there can be a minimum amount of funds that should be invested in domestic government bonds. This steers pension funds towards the same assets, aggravating herding behaviour.

${ }^{24}$ Note that buys and sells are equal at the highest level of aggregation. Thus there is no herding at this level. However, we have only used Dutch pension funds that would mitigate this problem.

${ }^{25}$ The measure is unable to distinguish between spurious herding and intentional herding.
} 
$B_{i t}$ is the number of pension funds that are purchasing long-term sovereign bonds in country $(i)$ (e.g. longterm Belgian government bond) in month $(t)$, whereas $S_{i t}$ indicates the number of pension funds selling long-term sovereign bonds in country $(i)$ in a particular month $(t) \cdot{ }^{26}$ Together they give the total number of pension funds trading in that month. Thus $p_{i t}$ gives the proportion of buys for country $(i)$ in month $(t)$. $p_{t}$ is the proportion of Dutch pension funds buying long-term sovereign bonds in a particular month. It simply indicates whether pension funds are purchasing or selling an asset class (in this case, long-term sovereign bonds), irrespective of the country. Note that the difference between the proportions is given in absolute terms, so this first part of the equation (1) is always positive.

$$
A F_{i t}=E\left[\left|p_{i t}-p_{t}\right|\right]
$$

$A F_{i t}$ represents the adjustment factor ${ }^{27}$ and $E$ denotes the expectation operator. The expected outcome is the sum of all possible outcomes times their probability of occurring. Following the herding literature, we assume $p_{t}$ to equal the proportion of buys by all Dutch pension funds of long-term government bonds in period $(t)$. It thus accounts for fluctuations in the month-by-month investment decisions made by pension funds, irrespective of the countries. Note that the LSV herding measure $\left(H M_{i t}\right)$ is calculated for all longterm government bonds in country $(i)$ in every month $(t)$. In other words, the herding behaviour displayed by pension funds differs for each month and destination country.

Some studies show that different behaviour may apply to sell and buy herding. Since we investigate extreme market circumstances, phenomena like fire-sales may play a role. Following Wermers (1999), we differentiate between buy and sell herding. ${ }^{28}$

$$
\begin{aligned}
& B H M_{i t}=H M_{i t} \mid p_{i t}>p_{t} \\
& S H M_{i t}=H M_{i t} \mid p_{i t}<p_{t}
\end{aligned}
$$

The financial literature identifies some limitations of the LSV herding measure. First, Bikhchandani and Sharma (2000) note that the measure fails to account for the size of the transaction. Our study deals with this shortcoming in several ways. We use a minimum sufficient size for transactions as suggested by Andreu et al. (2014) and Frey et al. (2014). In addition, as a robustness check, an estimation is conducted weighting for transaction size. Second, the LSV herding measure is unable to capture the inter-temporal

\footnotetext{
${ }^{26}$ Our study uses net sales or purchases.

27 Among other aspects, the $A F_{i t}$ also corrects the LSV measure when there are only a small number of trades. In addition, it corrects for the possibility that the number of pension funds' trades cannot equal the proportion of buys by all Dutch pension funds of long-term government bonds in period $\left(p_{t}\right)$.

${ }^{28}$ Wermers (1999) gives a more detailed explanation of the necessity to distinguish between buy and sell herding.
} 
trading pattern. Thus, our measure is unable to identify whether pension funds implement trading strategies over multiple months. In such a case, the trading decision is the consequence of a decision made in a previous month and should not be identified as following behaviour. We overcome this problem identified by Sias (2004) using position continuing trades. If the direction of trades is the same in the following month, it is identified as an implementation of a trading strategy over several months. Therefore, if we use the position continuing trade criterion, this study disregards the trades over the following months if the direction of trade is not changed. ${ }^{29}$

Third, Lobão and Serra (2002) note that the LSV herding measure does not indicate a specific cause of herding behaviour. We do not regard the causes as mutually exclusive contrary to the suggestion of Lobão and Serra (2002). This study identifies the triggers of herding behaviour such as economic and financial circumstances. Fourth, an important underlying assumption of the LSV herding measure is the no short-selling constraint mentioned by Wylie (2005). If this assumption does not hold, the LSV sell herding measure is underestimated. This results from the fact that for a sell to occur, there must be a buy transaction first. In other words, the buy herding measure becomes stronger (biased upwards) vis-à-vis the sell herding measure (biased downwards). However, Dutch pension funds are not bound by this shortselling constraint as discussed in Section 3. Our data shows some episodes where individual Dutch pension funds were short in long-term sovereign bonds in a country. ${ }^{30}$ However, there is still the possibility of a missing market. Relatively low trading volumes typifying frontier markets would suggest that short-selling is an activity not feasible in these markets (Economou et al., 2011). We address this issue using different minimum monthly trading intensities at the country level (e.g. more than or equal to three, five, ten or fifteen trades by Dutch pension funds in a specific month), this gives an indication of whether short-selling is feasible. ${ }^{31}$ We also re-estimate our results using minimum holdings. If the end-ofperiod holdings are positive, they can be sold in the following period. Consequently, the possibility of sell herding is believed to be equal to that of buy herding if holdings are positive and exceed a minimum threshold.

Fifth, Wylie (2005) notes that the ex-ante probability of a fund manager buying an asset depends exclusively on the extent of herding behaviour. This can be questioned for the low and middle income countries in our sample in particular. Low liquidity in the sovereign bond market may result in delays in order executions. Therefore, observed herding behaviour may simply result from the illiquidity of some

\footnotetext{
${ }^{29}$ The introduction of the Sias (2004) herding measure is beyond the scope of this paper.

${ }^{30}$ In a specific country, even the aggregate portfolio of Dutch pension funds was short.

${ }^{31}$ Societal pressures may also result in an effective no-short selling constraint. England banned short-selling for much of the eighteenth and nineteenth centuries, while in 1803, Napoleon declared short sellers to be enemies of the State (Jones, 2015). However, our data shows clear evidence that a (societal) short-sell constraint is not binding or ineffective because Dutch pension funds are short in some countries.
} 
sovereign bond markets. If this is true, the monthly number of trades for each country can partly account for the liquidity of the market. In general, a high number of trades over a specific period indicates a highly liquid sovereign debt market.

We conduct pooled OLS and LSDV ${ }^{32}$ regressions to identify the causes of herding behaviour in the sovereign bond market. ${ }^{33}$ There are some merits of using panel estimations over cross-section. ${ }^{34,35}$ First, it enables us to use the monthly data on holdings and transactions whereas cross-section uses the average across all months. Second, it accounts for unobserved country-pension fund fixed effects. This study uses the LSV herding measure $\left(H M_{i t}\right)$ as a dependent variable in our specification. However, due to the different behavioural effect on the buy and sell side, this study presents different effects on the buy and sell side, we also use the buy $\left(B H M_{i t}\right)$ and sell herd measure $\left(S H M_{i t}\right)$ proposed by Wermers (1999) as a dependent variable for robustness reasons. Due to the different behavioural effects on the buy and sell side, this study often presents the results for the buy and sell herding measure only. Our regression is specified as follows:

$$
H M_{i, t}=\mu_{i}+\beta_{1}^{\prime} M_{A C R O} O_{i, t}+\beta_{2}^{\prime} F I N A N_{i, t}+\beta_{3}^{\prime} F U N D_{i, t-1}+\varepsilon_{i, t}
$$

We divide our variables into three broad categories, i.e. indicators of macroeconomic circumstances, financial market sentiment and pension fund characteristics. ${ }^{36} M A C R O_{i, t}$ is a vector which includes the macroeconomic variables, like inflation, the current account balance, exchange rate movements, GDP growth, general government debt, the unemployment rate, net lending by the government, Standard \& Poor's (S\&P) credit ratings and outlook. ${ }^{37}$ These variables are all believed to influence the appetite for

\footnotetext{
${ }^{32}$ Following Raddatz and Schmukler (2012), we estimate the fixed effect using the Least Square Dummy Variable (LSDV) method. Our sample includes 73 months, which allows us to estimate our fixed effects specification with a very small asymptotical bias (the bias is of the order $[1 / T]$ ). The average time-frame by country-pension fund equals 52.1 months.

${ }^{33}$ We also use truncated regressions as a robustness check because the values of the dependent variable can only be within a certain range. The truncation takes place below -0.5 and above 0.5 . As the results are relatively similar, they are not included in this paper, but they are available on request.

${ }^{34}$ Using fixed effects, we reduce the possible bias from the country-pension fund fixed effects. To further deal with the data structure, we clustered at the country level and at a monthly basis.

${ }^{35}$ We conduct the Harris-Tsavalis (1999), Im-Pesaran-Shin (2003) and Pesaran (2007) panel stationarity tests and adjust the data to cover data gaps. Our choice for these tests is driven by the large number of country-pension fund panels $(N=1961)$ and relatively small time dimension $(T=73)$. Our preferred test is the Pesaran (2007) tests which allows for unbalanced panels and cross-sectional dependencies.

${ }^{36}$ Most of the variables differ by country and over time. There are some notable exceptions; however, pension fund size differs only on a pension fund basis. Furthermore, the VIX index only differs per month as it is a global index.

${ }^{37}$ According to the sovereign rating literature, there are two major rating agencies, being S\&P and Moody's. We decided to use S\&P as it is considered to be the lead rating agency. Gande and Parsley (2014) show this using the Cooper et al. (2001) leader-follower ratio.
} 
investing in government bonds, and reflect the viability of the underlying economy. In addition, it is to be expected that most pension fund managers have direct access to this information.

The vector $\left(\right.$ FINAN $\left._{i, t}\right)$ captures the developments on the different financial markets, for instance the trend of share prices, CDS spreads, long-term government bond yields and the VIX index. These indicators include local as well as global trends on the financial markets. An example of a local phenomenon is share price movements on the domestic stock exchange and a global phenomenon can be the change in the VIX index. The VIX index is often interpreted as a measure of global risk aversion (International Monetary Fund, 2014). In this way, we distinguish between the influence of local and global market circumstances on herding behaviour.

The vector $F U N D_{i, t-1}$ comprises pension fund characteristics. Following Bikker et al. (2007), we include these variables with a lag to limit endogeneity problems. ${ }^{38}$ The vector includes the logarithm of the size of the pension fund to incorporate the effect of in-house analysing capacity. ${ }^{39}$ The distance to the government bond strategic asset allocation is included to account for additional purchases or sales in order to meet the strategic asset allocation. Trading can also result from a pension fund's risk preference. We estimate risk preference by the ratio of equity and private equity holdings to fixed-interest investments. The inclusion of the funding ratio is motivated by the fact that it may influence the risk appetite and risk taking of a specific pension fund (e.g. gamble for redemption). After Calvo and Mendoza (2000), this study also aims to establish whether the share of a pension fund's sovereign holdings in a specific country influences herding behaviour. Small sovereign bond holdings are relatively costly if there are countryspecific fixed costs for bond investments. This makes mimicking behaviour a rational choice. We also account for the preference of relative high past returns by using the ratio between the returns on fixedinterest investments and total returns. In this way, we can account for return-chasing behaviour in the pension fund's asset portfolio. ${ }^{40,41}$

The inclusion of these variables allows us to test for the different drivers of herding behaviour. The specification does not assign different weights to the various explanations, and allows for the simultaneous occurrence of multiple explanations. We also examine the influence of financial market and macroeconomic circumstances on herding behaviour (e.g. a crisis or a tranquil period).

\footnotetext{
${ }^{38}$ This study implicitly assumes that pension funds cannot influence the macroeconomic and financial market circumstances on their own. Whether this assumption still holds for them as a group, is subject to investigation.

${ }^{39}$ This study uses the logarithm of the pension fund's size to ensure that the two largest funds do not disproportionally influence our results.

${ }^{40}$ Note that our study does not suffer from the standard problems following from micro data. For example, we do not aggregate individual pension fund data.

${ }^{41}$ While we employ numerous controls, herding behaviour may still be influenced by other unspecified factors. These omitted variables can cause bias. Pension funds' herding behaviour can have many causes, which makes it difficult to account for all factors. To account for some of these factors, we already control any constant country-fund omitted factors. As a robustness check, we also use country fixed-effects.
} 


\subsection{Data}

We make use of two unique micro datasets of De Nederlandsche Bank ${ }^{42}$ on the holdings of Dutch pension funds. The balance of payments statistics dataset includes monthly transaction data of Dutch pension funds where individual long-term sovereign bonds are aggregated on the country level for each pension fund. It includes value changes divided into net purchases or sales, ${ }^{43}$ price movements, exchange rate adjustments and other changes. This makes our study unique as we do not need to estimate sales and purchases from holdings data. The data also includes the holdings at the beginning and end of a period and the destination country of investment at the country level per pension fund. We have transaction data for 67 pension funds on sovereign bond investments in up to 109 countries. Our data covers the period between December 2008 and December 2014, in total 73 months. Together we have 60,626 countrypension fund-month combinations. The strength of our data is their high (monthly) frequency. DNB's supervisory dataset includes pension fund specific information. We distil the funding ratio, strategic asset allocation, fund size, and other characteristics from this dataset. Further, we add data on macroeconomic and financial market circumstances, obtained from the World Bank, Standard \& Poor's, different central banks and the OECD (for more details, see table 31).

Our study focuses on sovereign bond holdings of pension funds. This allows us to investigate the investment behaviour of pension funds during the European debt crisis, and to assess their behaviour during tranquil and crisis times and compare the two. Our analysis uses direct holdings of long-term sovereign bonds. Long-term sovereign debt on average comprises $98.8 \%$ of the direct sovereign debt holdings of Dutch pension funds. Short-term sovereign debt is also used for liquidity management, which makes it difficult to assess whether this is an investment or liquidity management decision. In addition, the direct long-term sovereign debt holdings are highly diversified across countries, which allows us to test herding behaviour in all kinds of macroeconomic circumstances.

Tables 3 and 4 provide summary statistics of the control variables and balance of payments statistics. The LSV herding measure is calculated based on sovereign bond purchases and sales of pension funds.

[insert tables 3 and 4 here]

The LSV herding measures are calculated in different ways. Figure 1 shows a univariate kernel density function with the LSV herding measure for a minimum of five trades. The figure shows that sell herding is

\footnotetext{
${ }^{42}$ De Nederlandsche Bank is also responsible for the supervision of pension funds in the Netherlands.

${ }^{43}$ Our analysis is adjusted for accrued interest as we do not regard this as a net purchase of a pension fund.
} 
more intense (sometimes over 0.4 ) than buy herding. Our study also discusses the accrued interest rate. If we adjust for the accrued interest rate by the country-specific interest rate ${ }^{44}$, herding is more pronounced for all three categories (see figure 2).

[insert figures 1 and 2 here]

Dutch pension funds held long-term sovereign bonds in 109 countries (see figure 3). This provides for a broad geographic and cultural spread, and variation in economic circumstances. Although pension funds invest in a diverse set of countries, the size of their investments differs considerably (see figure 4).

[insert figures 3 and 4 here]

For several reasons, our study provides conservative estimates of pension fund herding behaviour. First, our analysis only includes direct investments of Dutch pension funds and disregards indirect investments. This excludes herd behaviour exhibited by external asset managers which act on the behave of a pension fund. Multiple pension funds can have the same external asset manager which can result in similar trading behaviour. In other words, pension funds could have selected the same asset manager who is likely to mimic him- or herself for multiple pension funds. ${ }^{45}$ By using direct investments, we make sure that the observed herding behaviour is based on a pension fund's own decisions. This also gives more heterogeneity in possible outcomes, due to the different strategies pursued by the asset managers of individual pension funds.

Second, holdings of long-term sovereign debt are assumed to be managed more passively than equity or corporate bond investments. Third, in comparison with open-end funds, herding is likely to be lower as the assets of Dutch pension funds cannot be directly redeemed by their members. This effectively rules out herding behaviour by fund investors, which can sometimes be observed for mutual funds (Kaminsky et al., 2004).

\footnotetext{
${ }^{44} \mathrm{We}$ adjust for the accrued interest by imposing a minimum net purchase because a net purchase can occur due to accrued interest. The accrued interest is added as a purchase in the balance of payments statistics. We adjust for this by imposing a minimum of the purchase equal to the prevailing long-term interest rate in that particular country.

${ }^{45}$ Pension fund asset managers may be influenced by their external asset managers (e.g. presentations, roadshows or investment information). This study only uses direct investments by pension funds because our analysis reveals that pension funds with the same external asset manager do not exhibit different herd behaviour than pension funds with different external asset managers. We checked this with data from DNB's pension fund supervision dataset. Annual data is available on asset management firms that manage over $30 \%$ of holdings of a specific pension fund. For our sample, the number of different asset managers is 175 . We identify the pension funds with matching asset managers. These pension funds do not exhibit more intensive herding behaviour than pension funds that use different asset managers. Thus, our findings are not driven by underlying herding behaviour due to similar information from the external asset management firm.
} 


\section{Empirical results}

\subsection{Herding behaviour}

\subsubsection{Herding behaviour of pension funds}

Herding behaviour can only occur if there is a minimum amount of purchases or sales in an asset. In our case, there must be multiple pension funds trading in a long-term sovereign bond of country $(i)$ during month $(t)$. DNB's balance of payments statistics includes the accrued interest rate ${ }^{46}$ in sales and purchases. Accrued interest are interest earnings not yet received by the pension fund (e.g. they are paid out on a specific date). In other words, accrued interest increases the value of the sovereign holdings, therefore, this is recorded as a purchase of sovereign bonds. In order to identify a genuine purchase, we adjust the sales and purchases by the accrued interest. We account for the inclusion of accrued interest in the purchases ${ }^{47}$ by introducing a minimum amount of purchases, the purchases should be higher than the prevailing interest rate. This accounts for the possibility that the purchase is just the addition of the accrued interest. We use two interest rates for these corrections: the long-term interest rate and the longterm interest rate augmented by the average continental interest rate for missing values ${ }^{48}$ (referred to below as the augmented interest rate). The first has as the advantage that it is the best approximation of the accrued interest rate, whereas the second enables us to estimate herding behaviour for more countries.

[insert table 5 here]

Table 5 shows that the herding measures corrected by the country-specific interest rate reveal more intensive herding. The overall, buy and sell herding measures are $0.14,0.12$ and 0.16 , respectively. The herding measure including the augmented interest rate gives a lower intensity of herding. Overall, buy and sell herding are $0.09,0.08$ and 0.11 , respectively. This is somewhat lower than the country-specific estimates. However, herding in sovereign bond investments is still more intensive than it is in equity investments. On average, the herding measure equals 0.12 , whereas the herding measure obtained for equity investments is around 0.03 (Lakonishok et al., 1992; Grinblatt et al., 1995; Jame, 2011).

\footnotetext{
${ }^{46}$ Accrued interest are interest earnings not yet received by the pension fund (e.g. they are paid out on a specific date).

${ }^{47} \mathrm{We}$ ignore sales because accrued interest is deemed to be positive. Therefore, applying a cut-off to sales is not necessary.

${ }^{48}$ The accrued interest is corrected by the prevailing interest rate augmented with WEO country groups' average interest rates.
} 
Position continuing trades could play a role in the observed herding behaviour. Pension funds can potentially follow their own investments (e.g. Sias, 2004). Implementation of an investment decision can take several months, especially if the decision is taken at the end of the month. This study accounts for pension funds following their own purchases or sales by disregarding position continuing trades, i.e. it only uses the initial investment decision. The consecutive country-pension fund observations are not included up to the point where the pension fund changes its trading behaviour (e.g. from purchasing to selling the sovereign or from selling to not trading). The downside of this approach is that subtle differences are disregarded. Pension funds can for example decide to intensify purchases of a specific sovereign bond.

The herding measures correcting for position continuing trades reveal some different behaviour than the previous measures. The buy herding measure is considerably higher than the sell herding measure. This contrasts with our earlier findings where the opposite holds. The buy herding measure is 0.16 whereas the sell herding measure is 0.06 . Thus, buy herding is almost three times as intensive. These results may indicate that selling is a process that takes several months whereas buy herding is more tied to a specific month. Price pressures may be a reason for these differences.

[insert tables 6 and 7 here]

The trading intensity can potentially affect the intensity of herding, as shown in tables 6 and 7 . We use four restrictions on the number of trades, i.e. three, five, ten or fifteen trades. ${ }^{49} \mathrm{~A}$ higher minimum number of trades gives a more restricted sample. In general, the overall and sell herding measures decline if the minimum number of trades increases. For the country-specific interest rate, sell herding declines from 0.16 with a minimum of three trades to 0.05 with a minimum of fifteen trades. In a similar vein, although less pronounced, the augmented interest rate shows a decline from 0.11 to 0.07 . This could be explained by unintentional and intentional herding motives. Prompt incorporation of new information and similar interpretation of this information by pension funds can lead to unintentional herding. Pension fund portfolio managers may window dress their portfolios, shedding 'exotic' sovereigns more because large sovereigns are in the portfolios of most portfolio managers. Whereas on the buy side, pension funds continue to buy small sovereigns for return considerations.

Lakonishok et al. (1992) state that intentional herding should also be more prevalent in small equities, which could also apply to smaller sovereigns. A tentative explanation is that a higher number of trades indicates a more vibrant or larger sovereign debt market. This probably resembles the fact that

\footnotetext{
${ }^{49}$ Where there is no mention of a minimum number of trades, this study uses a minimum of five trades per month.
} 
trading is more frequent in advanced and large economies. There is more (public) information available on these large and vibrant sovereign bond markets. For small sovereigns, portfolio managers are more inclined to infer information from other managers. Scharfstein and Stein (1990) and Rajan (2006) note that underperformance may have an adverse effect on portfolio managers' career prospects. In addition, it is more socially acceptable to hold on to French sovereign bonds when other asset managers sell these bonds than to hold on to Zambian sovereign bonds.

This study also uses position continuing trades, covering the possibility that trades are implemented over several months. We find relatively large buy herding measures, they range between 0.12 and 0.16 depending on the correction for the accrued interest rate and the number of trades. These findings are similar to that of Balagyozyan and Cakan (2016). Their results indicate that herding was much more prevalent in the run-up to the Dot.com bubble than during the collapse. Our findings give some indicative evidence in this direction because following behaviour seems to be more pronounced on the buy than on the sell side when we only regard the initial purchase or sell decision.

\subsubsection{The extent of herding}

This study examines the extent of herding behaviour in different countries. Figure 5 shows that herding may be country specific. The buy herding patterns reveal that buy herding seems to be concentrated in Europe and Africa. The 'safe haven' status of specific countries seems to have influenced trading in Europe. Bijlsma and Vermeulen (2016) also observed a flight to quality between 2006 and 2013 for Dutch insurers. In Africa, buy herding seems related to a search for new investment opportunities as African sovereign bond holdings accelerated the most over our sample period.

[insert figures 5 and 6 here]

Figure 6 shows sell herding by country. Generally, sell herding is more pronounced than buy herding. The level of herding on the sell and buy side also overlaps. Dutch pension funds again exhibit a high level of herding in European and African countries. However, herding behaviour is also strong in Latin America compared to other continents. In summary, there seems clear evidence that the level of herding may be influenced by country-specific factors. Moreover, these figures provide no evidence that herding is concentrated in emerging market economies only.

We investigate the differences in the extent of herd behaviour between safe havens and countries affected by European debt crisis. This study uses different definitions of safe havens and European debt 
crisis countries to assess the robustness of our findings. ${ }^{50}$ Our findings reveal a difference between buy and sell herding for safe havens. The buy herd behaviour ranges from 0.14 to 0.15 , whereas sell herd behaviour ranges from 0.03 and 0.06 . For our entire sample period, we do not find a considerable difference in the extent of buy and sell herd behaviour for European crisis countries. This finding is somewhat surprising, thus we further focus on the European debt crisis period. Our study defines the period of the European debt crisis from May 2010 to July 2012. The European debt crisis starts with the first bail-out for Greece, whereas it ends with the famous remark from Mario Draghi in July 2012: he would do "whatever it takes". From table 8 , it is clear that the safe havens experience substantially higher buy herd behaviour ranging from 0.13 to 0.15 compared to crisis countries. Pension funds do not buy herd in the crisis countries, the LSV herding measures range from 0.03 to 0.07 . On the sell side, the different between safe havens and crisis countries is even more pronounced. The LSV sell herding measures for safe havens range from 0.02 to 0.06 . The pension funds exhibit substantially more intensive herd behaviour in crisis countries which ranges between 0.15 and 0.24 . These results are consistent with our expectations. In crisis circumstances, the risks substantially increase in these countries. There could be different explanations for this behaviour. When there is high uncertainty, pension funds might not be willing to deviate from each other in their investment portfolio. During the European debt crisis, considerable new information became available on the crisis countries which might drive herd behaviour.

[insert table 8 here]

We also explore differences in herding behaviour by quintile analysis. Tables 9 and 10 show whether pension fund characteristics, financial market sentiment and macroeconomic circumstances play a role of significance in herding. The quintiles are constructed on a monthly basis. For each month, we divide the indicator into five equally sized groups (from low to high). We elected to construct monthly quintiles as purchase and sell decisions are mostly influenced by the comparative macroeconomic and financial market situation in a particular month.

[insert tables 9 and 10 here]

We are especially interested in the specific patterns that could be observed between quintiles. Our findings reveal clear herding patterns for sovereign ratings, GDP growth, the size of the sovereign debt market, the

\footnotetext{
${ }^{50}$ Safe haven (1) consist of Germany, the Netherlands, Switzerland and Finland. Safe haven (2) adds Austria to the list. Furthermore, safe haven (3) adds Denmark, Norway and Sweden. The PIIGS include Cyprus, Greece, Ireland, Italy, Portugal and Spain. The definition of financial aid recipients excludes Italy, whereas the definition of rescue package recipients further excludes Spain.
} 
number of countries in a pension fund's sovereign bond portfolio, interest rates, the CDS spread, the current account, the average monthly sovereign holdings of a pension fund, sovereign holdings in a country as a percentage of the pension fund's total sovereign holdings, corruption, political stability, regulatory quality, the absolute distance to the strategic asset allocation, the pension fund's size and the country's yield. Note that these indicators are potentially correlated, therefore, the results should be interpreted with care. As a robustness check, we conduct a similar exercise correcting for the accrued interest by the augmented interest rate. Most of our results prove to be robust, except GDP growth, the current account, corruption, regulatory quality and pension fund size. Note that previous results should be interpreted with care, because the various indicators may be correlated and, in this paragraph, we only observe unilateral results.

Sell herding is driven by the macroeconomic and financial market circumstances. High yields lead to more intensive sell herding and lower buy herding and vice versa. Sell herding in the lowest yield quintile equals 0.05 whereas sell herding in highest yield quintile equals 0.23 . The opposite pattern is observed for buy herding, with the low yield quintile at 0.14 and in the high yield quintile at 0.07 . These results indicate that the investment decisions made by Dutch pension funds do not seem to be primarily driven by yield. Higher yields are a compensation for higher risks (e.g. a less stable macroeconomic or political environment) and pension funds seem to be unwilling to take these (additional) risks. Earlier studies by Bikker et al. (2010) and de Haan and Kakes (2011) also show that pension funds do not act as return chasers. They also regard the potential risk of their sovereign investments.

This study finds similar results for long-term interest rates. Herd behaviour is also influenced by the CDS spread. In similar vein as the sovereign yield, higher CDS spreads increase sell herd behaviour. Another factor influencing herding is the size of the sovereign bond market. The overall and buy herding measures show that a larger sovereign bond market to some extent isolates the country from herding behaviour.

The general economic environment is also important for the existence and extent of herding behaviour. Sovereign bond ratings are taken to include numerous aspects of the macroeconomic environment, like GDP per capita, GDP growth, inflation, external debt, level of economic development, default history, unemployment rate, the investment-to-GDP ratio, foreign reserves, current account balance, exports, terms of trade, fiscal policy and political risk (Afonso et al., 2011). Thus, credit ratings may be viewed as a summary of the macroeconomic situation in a country. The sovereign debt rating is numerically transformed by defining AAA (1) and D (22) (see table 11) and the rating outlook is numerically transformed by negative $(-1)$, stable $(0)$ and positive $(+1)$. We find that low sovereign ratings intensify sell herding. Sell herding for the highest rated countries is 0.04 , and 0.26 for the lowest rated countries. This gives some indication that Dutch pension funds sell their investments from low rated 
countries simultaneously. However, the institutional setting also proves to be important. Pension funds are regarded as long-term investors. Our findings show high buy herding in times of high political stability. Pension funds seem to value low political risk. Buy herding increases from 0.08 for countries with a low level of political stability to 0.17 for countries with a high level of political stability.

The structure of a pension fund's sovereign holdings is also relevant for herding behaviour. Pension funds with large sovereign holdings show more pronounced sell herding behaviour. A possible reason for this is that these funds want to bring their sovereign portfolio size more in line with that of other funds. Da et al. (2015) find more intensive sell behaviour if pension funds have large sovereign bond portfolios, which is not surprising as these assets dominate the portfolio holdings and they are generally relatively liquid. Besides the fact that portfolio size affects herding behaviour, we find evidence that portfolio composition is relevant for herding behaviour. Our findings reveal indicative evidence that there is an information advantage if pension funds hold a sizeable share of their sovereign portfolios in a specific country. Sell herding declines from 0.21 for the countries that account for a small proportion of the sovereign portfolio to 0.04 for countries that account for a large proportion of the sovereign portfolio. This can be explained by the different incentives for information collection. Small sovereign bond holdings are relatively costly if there are fixed costs for country-specific investments as noted by Calvo and Mendoza (2000). Consequently, for small investments pension funds may rely more on the information they infer from trades made by other funds. Interestingly, this effect cannot be observed on the buy side. A related factor is the number of countries in a pension fund's sovereign bond portfolio. The results are highly similar compared to the proportion of sovereign holdings in a specific country. Sell herding increases with the number of countries represented in a sovereign portfolio.

As a robustness check, we also construct quintiles over the entire sample period. ${ }^{51}$ Pension fund characteristics, macroeconomic and financial factors influence herding behaviour. This approach has some merits over the monthly quintile approach. Redefining the quintiles on a monthly basis can lead to differences in the quintile cut-offs between the months, which can potentially influence our results. However, the previous estimations are quite robust because the results for the constructed quintiles over the entire sample period prove to be highly similar.

\subsubsection{Determinants of herding behaviour}

We observed that pension funds' herding behaviour differs considerably with the financial market conditions, the macroeconomic environment and pension fund characteristics. However, the quintile analysis does not account for the relationships between indicators. The correlation coefficients reflected in

\footnotetext{
${ }^{51}$ Detailed results are available on request.
} 
table 12 reveal multiple significant relationships between financial and macroeconomic indicators. We will now include the indicators simultaneously to determine the driving forces of herding behaviour in the sovereign bond market, while giving an indication of their magnitude. Due to our relatively large sample, statistical significance is insufficient to conclude that an indicator contributes to herd behaviour (e.g. Granger, 1998).

[insert table 12 here]

We prefer using the LSDV regression as its estimation bias decreases with the number of time periods. On average, the country-pension fund panels include over 52 consecutive months of observations. This is a large time-component, particularly when compared to standard macroeconomic panels. The OLS results are included for completeness reasons. However, these estimates can be biased, since herding may depend on unobserved country-pension fund and time-fixed effects. We will mainly focus on the results of our preferred model.

Table 13 shows buy herding at different trading intensities. We distinguish 3, 5, 10 and 15 trades in columns (1)-(4) for OLS and (5)-(8) for LSDV, respectively. Our findings are relatively similar across specifications with a minimum of between 3 and 10 trades. The regression at a minimum of 15 trades reveals some notable differences compared to the other specifications. GDP growth has an insignificant effect on buy herding and a negative significant effect in the other regressions. In addition, the VIX index has a positive effect and an insignificant effect in the other specifications. The VIX index represents an indication of global risk aversion. The positive buy herding for highly traded sovereigns can be a flight to quality as observed for Dutch insurance companies by Bijlsma and Vermeulen (2016). Frequently traded sovereigns are highly liquid, even under uncertain conditions. In addition, high-rated sovereigns experience less buy herding, which may be explained by the fact that high frequency of trading reduces the probabilities of forming a herd. The largest economically significant effects result from sovereign ratings and the size of the sovereign bond market. The size of the sovereign bond market depresses the LSV herding measure by 0.09 if it increases by one standard deviation. Thus, the size of its sovereign bond market makes a country less prone to herding behaviour.

[insert table 13 here]

Table 14 presents sell herding behaviour at different trading intensities. The lagged percentage of sovereign holdings is negative and significant, except at a minimum of 15 trades. Small sovereign bond holdings are relatively costly if there are fixed-costs for country-specific investments as noted by Calvo 
and Mendoza (2000). Consequently, there is more sell herding in small sovereign holdings. This relates to the findings of Choi et al. (2017), which suggest that concentrated investment strategies in international markets can be optimal. The probability of sell herding decreases with the size of the sovereign bond market. First, the size of the government bond market is related to market liquidity. Thus, professional investors might worry less when other pension funds move out of these markets. Second, from an investment manager's perspective, it is easier to justify holdings of sovereign bonds issued by large economies. Scharfstein and Stein's (1990) interpretation of the shares of large companies (e.g. IBM) may also apply to large sovereign bond markets. Third, information costs are likely to be lower on average for larger holdings and for large sovereign bond markets (e.g. information updates are more frequent). The size effect is also highly significant from an economic perspective. A one standard deviation adjustment substantially decreases the LSV herding measure by 0.20 . A low sovereign rating increases sell herd behaviour, except in the case of a minimum of 15 trades. There is a stark contrast between the behaviour for sell and buy herding. This is not surprising, since a high sovereign rating may be a reason to buy a particular bond, whereas the opposite holds for low sovereign ratings. This effect is also economically relevant.

[insert table 14 here]

In general, the specifications for a minimum of 15 trades differ from the other specifications. ${ }^{52}$ This is attributable to the smaller sample size. In addition, a higher minimum trading threshold means that only frequently traded bonds are included. We follow the accepted practice in the herding literature by presenting our findings for a minimum of five trades. This assures that the herding behaviour found does not result from random change, and a diverse set of countries is included (i.e. not just the frequently traded sovereign bonds). This also makes our results better comparable to other herding behaviour studies.

According to our quintile analysis, pension fund characteristics have limited relevance for herding behaviour, but our analysis suffers from some econometric problems. Following Bikker et al. (2007), the pension fund characteristics are lagged to mitigate some of the endogeneity problems. Table 15 shows that the relative performance of fixed-income investments as compared to the total performance of all pension fund investments influences buy herding behaviour. A better relative performance significantly increases buy herding, which may among other things be attributable to adjustment of the tactical asset allocation. This refers to taking short-term (informed) bets on relative asset class returns (Bikker et al., 2007). If we include all pension fund indicators simultaneously in columns 7 and 14, the relative performance indicator

\footnotetext{
${ }^{52}$ This sample is dominated by German and Dutch sovereign bonds.
} 
remains significant. All other pension fund characteristics are insignificant. For sell herding behaviour, we find no significant effects of pension fund characteristics in table 16. At first glance, the irrelevance of most pension funds' specific characteristics is rather surprising. The low relevance is confirmed by the low economic relevance of pension fund characteristics. They have a limited effect on herding behaviour. One explanation for these results may be that pension fund characteristics persist over time. Consequently, the variation is too small to produce any significant effect.

[insert tables 15 and 16 here]

Our previous findings show that the macroeconomic situation may play an important role in herding behaviour. Table 17 presents the results of the macroeconomic factors influencing buy herding. Our findings show a positive and significant effect of the current account on buy herding. A better current account position leads to increased buy herding, which may be explained by the fact that the current account serves as an indicator for the competitiveness of a country's economy. A current account surplus makes it easier to serve debt payments, especially if a country holds debt denominated in foreign currencies. Cassimon et al. (2008) note that this is particularly relevant for many developing countries as they rely on foreign capital to finance their budgetary needs. Exchange rate volatility has a negative effect on buy herding behaviour. For pension funds, volatility makes their investment revenues more insecure or they are required to hedge currencies to uphold their revenues.

We are somewhat surprised by our findings for government debt and net government lending. Both indicators increase buy herding behaviour, meaning that pension funds do not shy away from countries with high government debt or high net government lending needs. As said, this may due to liquidity reasons. Melecky and Raddatz (2015) contend that there are two opposing effects. Although countries have a higher probability of default if they have higher government debt and higher deficits, they often have better financial market access as their debt stock is the outcome of the supply of loans and the purchase of their government bonds. The economic significance is also very high, a one standard deviation increase in general government debt increases buy herding by 0.08 . The unemployment rate has a negative and statistically and economically significant effect on buy herding. Unemployment can have effects on government tax revenues and social security costs. If we include all macroeconomic indicators simultaneously, net government lending becomes insignificant. Table 18 shows the results for macroeconomic variables when sell herding occurs. These variables have the opposite sign to buy herding, and general government debt is insignificant. The other indicators are significant and signed as expected. The unemployment rate has an economically significant effect on sell herding. A high unemployment rate increases the level of sell herding by 0.07 . 
[insert tables 17 and 18 here]

Table 19 shows the influence of financial market sentiment on herd behaviour. We find no evidence that stock market returns influence buy herding behaviour. Our findings do reveal that the CDS spread has a pronounced negative effect on buy herding, in accordance with our expectations. A higher risk of default makes Dutch pension funds less willing to herd into that sovereign. The yield also has a negative effect on buy herding, so additional yield does not sufficiently compensate Dutch pension funds for the increasing likelihood of default. This contrast with the findings of Xiao (2007) on international bond funds. These funds chase bonds with high past returns and yields, whereas pension funds do not herd on contemporaneous yield. A high CDS spread and yield result in an economically relevant decrease of buy herding by 0.03 for both. Our estimated results in table 20 indicate that yield and the CDS spread do contribute to sell herding behaviour, whereas stock market returns have a negative and significant effect on sell herding behaviour. There is a clear economically significant effect of a one standard deviation increase in CDS spread and yield, the LSV herding measure increases by 0.06 and 0.04 , respectively. In summary, our findings reveal a clear influence of financial and macroeconomic conditions on sovereign herding behaviour.

[insert tables 19 and 20 here]

There is a debate in the literature on the effect of sovereign ratings and how rating changes affect the behaviour of sovereign bond investors. Pension funds exhibit more pronounced buy herding behaviour amid a positive rating outlook (see table 21 ). The rating outlook has a significantly positive effect on buy herding, so pension funds anticipate on possible improvements in sovereign ratings, but we find no evidence that their anticipating behaviour is more pronounced immediately following a change in the rating outlook. Our findings reveal that pension funds engage in buy herding following a sovereign rating change, meaning that they are incapable of correctly anticipating the timing of a rating change. The lack of anticipation may also imply that in some cases rating events for some reason go astray of the underlying macro and fiscal fundamentals that market participants perceive (Afonso et al., 2012). However, after a rating change, all pension funds seem to actively adjust their portfolios. Table 22 shows the sell herding results for rating and outlook changes. As expected, a positive outlook dampens sell herding. Pension funds hold on to these assets, probably because the probability of default decreases. In addition, improved sovereign ratings could be closer to their preferred asset characteristics as discussed by Falkenstein (1996). Contrary to the buy herding specification, a change in the rating outlook is significant, but the 
economic significance is rather low. The different indicators have a limited economically meaningful impact on herding.

[insert tables 21 and 22 here]

Institutional factors influence the investment behaviour of pension funds. Institutional factors are highly correlated, and we find mixed evidence on the effect of institutional factors on herding behaviour. There is a positive and significant effect for the variables of government effectiveness, regulatory quality and voice and accountability ${ }^{53}$ (see table 23). Voice and accountability has high economic significance, a one standard deviation improvement of this indicator increases buy herding behaviour by 0.27 . However, we also find a negative and significant effect for political stability and absence of violence/terrorism and rule of law. Improving the quality of institutions should slightly increase the likelihood of buy herding in a particular sovereign as it is more attractive as an investment. However, buy herding can also have destabilising effects (e.g. price pressure, bubbles etc.). Thus, better institutions might be able to prevent or mitigate buy herds. Consequently, the evidence is somewhat mixed. The same is true for sell herding behaviour (see table 24). Our findings reveal a negative and significant effect of better control of corruption, regulatory quality and voice and accountability. In contrast, we find a positive and significant effect for rule of law and political stability and absence of violence/terrorism. Our findings are somewhat similar to those of Gelos and Wei (2005) who find that international investors tend to flee more opaque markets. We will not discuss the results for the simultaneous inclusion of the institutional variables because our correlation coefficients reveal that the correlation of the institutional factors is often over 0.8 . Therefore, we should be cautious interpreting the results when simultaneously including these indicators.

[insert tables 23 and 24 here]

\subsection{Sensitivity analysis}

We perform various robustness checks. First, we adjusted the correction for the accrued interest rate. We assume that the accrued interest is the same as the prevailing interest rate at that moment. Although, this is a reasonable approximation, we investigate whether this assumption drives our results. The corrections are the world interest rate, the country specific interest rate augmented with the average world interest rate for missing observations, an annualised uniform interest rate of $10 \%$, the highest interest rate in the sample

\footnotetext{
${ }^{53}$ The World Bank (2015) defines the voice and accountability variable as "it captures perceptions of the extent to which a country's citizens are able to participate in selecting their government, as well as freedom of expression, freedom of association, and a free media."
} 
and the prevailing yield on long-term government bonds. ${ }^{54}$ The re-estimations of the LSV herding measure using these corrections prove to be relatively similar to our previous corrections. Thus, our findings are not driven by our decision to adjust the correction for the accrued interest rate.

Bikhchandani and Sharma (2000) indicate that the LSV herding measure does not incorporate the size of the transaction. We use absolute values of the purchases and sales to incorporate the size of the transactions. Please note that our main aim is to investigate herding behaviour. From this perspective, the size of the transaction is less important. However, transaction size does matter when regarding the possible price effects of herding. Larger transactions have a larger potential to influence the price setting. This robustness check allows us to check whether herding behaviour is driven by a high number of small transactions. We re-estimate our results weighting absolute trade size. This does not significantly change our results.

Pension funds sometimes outsource their asset management to external asset management firms. Indirect investments can be classified as investments into bond mutual funds. However, this still leaves the possibility that pension funds engage the services of the same external asset managers. We want to address this issue as pension funds' herding behaviour may be attributable to similar dealings by the same external asset manager. ${ }^{55}$ The difference between the LSV herding measure for pension funds with similar asset managers and non-similar ones gives an indication of herding due to the same external asset managers. Some pension funds engage more than one external asset manager. To account for multiple external asset managers, we perform an additional robustness check, assuming that the external asset managers manage sovereign holdings proportionally. Our findings reveal that the LSV herding measures do not differ between funds with similar asset managers and those with different asset managers. This can be explained by the fact that pension funds set different goals and have different risk attitudes.

To provide evidence on the sensitivity of our findings, we augment our econometric specifications. We perform our econometric analysis using country-pension fund and time effects. The country-pension fund fixed effects are the smallest group in our sample which enables us to control for the underlying most unobserved factors. Following Raddatz and Schmukler (2013), different fixed effects are

\footnotetext{
${ }^{54}$ All these corrections have advantages and disadvantages. First, the use of the world interest rate guarantees the maximal sample but it is likely to be a poor approximation of the accrued interest rate for many countries. Second, the $10 \%$ uniform correction filters out the small transactions. Consequently, we regard the transaction which can potentially lead price effects. However, the correction is likely to be incorrect approximation of the accrued interest rate at the country level. Furthermore, it does not adjust for interest rate fluctuations over time. Third, the highest prevailing interest rate suffers from similar drawbacks as the world interest rate. This assures that the correction is probably larger than the accrued in interest rate. For the world interest rate, there will be over- and underestimation of the accrued interest rate. Fourth, the yield on long-term government bonds is country-specific. However, the yield is not widely available. Therefore, the sample size is reduced.

${ }^{55}$ There is one drawback to our approach. The data does not allow us to distinguish between the external asset managers who manage the sovereign bond holdings and the other holdings.
} 
included in tables 25 and 26. Our results show that the sign and significance of our indicators is highly similar across specifications. ${ }^{56}$

[insert tables 25 and 26 here]

This study presents the pension fund, financial, macroeconomic and institutional indicators sequentially. To assess the statistical sensitivity of past findings and to control for a possible omitted variable bias, we include all significant controls simultaneously. ${ }^{57}$ These results do not change our main findings that economic and financial market circumstances within an institutional setting influence herding behaviour. Our results could potentially suffer from endogeneity. Herding by pension funds can influence the independent variables. We re-estimate our main specifications using only variables that are lagged by one period. Our results are not significantly different.

[insert figure 7 here]

We then estimate a dynamic panel model to account for possible autocorrelation. Figure 7 shows that there is no clear pattern in herding behaviour over time. Although there is no clear indication of persistence, we deal with possible autocorrelation estimating a dynamic panel regression. Our main specification is redefined as follows, and it includes a lagged dependent variable.

$$
H M_{i, t}=\mu_{i}+\phi H M_{i, t-1}+\beta_{1}^{\prime} M A C R O_{i, t}+\beta_{2}^{\prime} F I N A N_{i, t}+\beta_{3}^{\prime} F U N D_{i, t-1}+\varepsilon_{i, t}
$$

The lagged herding measures do not change the results for the other indicators. For both buy and sell herding, the lagged herding measure is negative and significant. Thus, high intensity herding behaviour is generally followed by low intensity herding behaviour.

We also apply a different econometric estimation methodology. We conduct truncated regressions as the herding measure is only continuous within a certain range, due to the attributes of the LSV herding measure. We have not included these regression results, due to space constraints. Furthermore, these findings do not differ substantially from the findings of the LSDV regression.

\footnotetext{
${ }^{56}$ The exception for buy herding behaviour is the insignificance of the VIX index for our initial specification. For the other two specifications, there is a positive and significant effect on buy herding. For sell herding, our preferred fixed effects show an insignificant effect for GDP growth, whereas the other specifications show a negative effect on sell herding behaviour.

${ }^{57}$ The institutional indicators are the notable exception as they are highly correlated among themselves.
} 


\subsection{Stabilising or destabilising effect?}

The question remains whether herding behaviour has a stabilising or a destabilising effect on sovereign bond prices. It could potentially be stabilising, $e . g$. when herding accelerates incorporation of information in bond prices (Nofsinger and Sias, 1999). We try to establish whether herd behaviour has a stabilising or destabilising effect by investigating the existence of return reversals. If herding behaviour indeed has a stabilising effect, no return reversals are expected. New information is included in bond prices, and will remain included in prices. If the effect is only behavioural, bond prices should reverse in the future. Pension funds will then ignore their own information and trade with the herd. This may move securities away from their price equilibrium and lead to abnormal volatility (Chang et al., 2000). This is the destabilising effect of herding behaviour.

We focus on the price returns and price returns plus exchange rate returns extracted from DNB's balance of payments database. We differentiate between these returns because exchange rate fluctuations are regarded as less predictable. In addition, total returns also sometimes include the effects of reclassifications. Following the standard practice in the financial literature, we also estimate the return reversals for winsorised returns. Pension fund investment managers mainly focus on their price return expectations. We do not know the exact transaction dates during the month so the exact returns are difficult to calculate on a monthly basis. These returns depend to a certain extent on the dates of purchases and sales. For now, we will use daily investments. We assume that there are 20 trading days in a month. Investments are made in equal daily amounts. We will check the robustness of our results later. We use our balance of payments data and assume different purchase and sales dates within the month, and we compare the results with sovereign market index returns data.

Our investigation includes the time of the European debt crisis. This may cause very volatile asset returns, especially in long-term government bonds. Potential outliers can influence our results on the stabilising or destabilising effect of herd behaviour. To control for this, the returns are winsorised in three different ways. The results are obtained for winsorising at 0.1 th and 99.9 th percentile, at 0.5 th and 99.5 th percentile and at 1 th and $99^{\text {th }}$ percentile. The latter winsorises more observations and, therefore, results in the inclusion of less outliers. The results are presented for winsorising at 0.1 th and 99.9 th percentile.

[insert tables 27 and 28 here]

We divide the buy and sell herding measures into quintiles. At period $t=0$, a pension fund either buys or sells sovereign bonds. The quintile which exhibits the strongest and the weakest buy herding are classified as $B 5$ and $B 1$, respectively. In a similar vein, we classify the sell herding measure. Thus $S 5$ is the quintile with the strongest sell herding, and $S 1$ is the quintile with the weakest sell herding. We investigate the 
abnormal return from two months prior to the transaction until five months after the transaction. In this way, we can see whether a return reversal occurs.

Our findings reveal some mixed evidence on stabilising and destabilising behaviour when using total returns. The average returns for sell herding behaviour are often statistically significant, whereas the results for buy herding behaviour are less significant. There are immediate return reversals for two sell quintiles, $S 3$ and $S 1$. This indicates destabilising behaviour of pension funds. When analysing the return reversals using price returns, our results also reveal mixed evidence on stabilising behaviour. There are also no significant return reversals for buy herding, except for $B 1$. Three sell herd return reversals are identified, these occur for the quintiles: $S 3, S 2$ and $S 1$. This are the relatively less intensive sell herding quintiles. In general, we find mixed evidence on stabilising behaviour. Destabilising behaviour seems to be occurring on the sell side, although it is concentrated in the low intensity sell herd quintiles. For buy herding, the pension funds behave in a stabilising way.

Country characteristics may potentially lead to different behaviour from pension funds. The most notable may be the difference in behaviour when controlling for sovereign ratings. Based on their ratings, we divide the countries in two groups: investment and noninvestment grade. For investment grade countries, we find some evidence of destabilising behaviour in sell herding when we look at price returns, even though not all immediate return reversals are statistically significant. The pattern of the signs reveals that a reversal also occurs in the insignificant cases, except for $S 5$. In the other specifications, we find no evidence of destabilising behaviour by pension funds. Thus, noninvestment grade countries do not suffer from destabilising pension fund behaviour. Another distinction can be made between emerging and advanced economies. When distinguishing between developing and emerging markets and developed economies, we find no clear distinction. For advanced economies, we find only sporadic evidence of destabilising behaviour. Our findings for emerging economies are highly similar. In general, we find stabilising behaviour by pension funds in developed and developing countries.

Investment decisions made by pension funds must also be reviewed at portfolio level. We start by sorting the sell and buy herding measures into quintiles per month $(t)$. Pension funds receive monthly inflows, and their investment managers must decide what to invest in. This paper combines the portfolio approaches of Wermers (1999) and Cai et al. (2012) to establish return reversals. We apply Cai et al.'s (2012) methodology as we want to compare the returns of different bond portfolios. We supplement their approach by one aspect of Wermers (1999), who did not weight returns by the size of the investment. This is a more suitable basis for our research as we want to observe herd behaviour, which by its very name is 
following behaviour. Thus, the value of the transaction is not at stake, but rather the execution of the transaction itself. ${ }^{58}$

We find some mixed results at portfolio level. When regarding all bonds, there are return reversals if pension funds go short in $B 1$ and long in $B 5$. This study distinguishes between investment grade and noninvestment grade bonds. For investment grade bonds, our findings reveal no immediate return reversals. By contrast, there is an immediate return reversal for noninvestment grade bonds if price returns are used; we find the same results for all bonds. Contrary to the results for total returns, we also find an immediate return reversal for investment grade bonds. The return reversion continues for a maximum of three months. As we do for ratings, we distinguish between emerging and advanced economies. Based on total returns, we find evidence that for $B 5-B 1$, there is a return reversal in developing and emerging economies. For advanced economies, our findings do not reveal any destabilising behaviour. If we use price returns, our findings also show destabilising behaviour for advanced economies at the level of portfolio $B 5-B 1$.

[insert tables 29 and 30 here]

In summary, we find mixed evidence whether pension funds act in a stabilising or destabilising way, but in most instances, their actions have a stabilising effect. When we analyse pension fund behaviour for each buy or sell quintile, we find some destabilising behaviour on the sell side. Whereas at portfolio level, we find destabilising behaviour when pension funds go long in quintile $B 5$ and short in quintile $B 1$.

There is no consensus in the herding literature on the question whether herding behaviour might be stabilising or destabilising. For equity investments, Wermers (1999), Nofsinger and Sias (1999) and Sias (2004) find no evidence of a destabilising effect, whereas Puckett and Yan (2008) and Dasgupta et al. (2011) find evidence of a destabilising effect. In their study on corporate bonds, Cai et al. (2012) show that destabilising effects are concentrated on the sell side and in junk bonds. These results are relatively similar to our findings for sovereign bonds.

Our mixed results can probably be attributed to the market circumstances, more particularly the existence of extreme returns. We use winsorised and non-winsorised returns to estimate stabilising or destabilising behaviour. We find that extreme market circumstances in the sovereign bond market increase the likelihood of finding a stabilising effect. In other words, if more extreme returns are winsorised, we do find more return reversals. One explanation for this may be that pension funds engage in more aggressive rebalancing behaviour. Their portfolio clearly deviates from their long-term strategic asset allocation,

\footnotetext{
${ }^{58}$ Following Wermers (1999), we also use a minimum of five trades.
} 
which necessitates aggressive adjusting of their sovereign holdings. If no adjustments are made when extreme returns materialise, the prevailing strategic asset allocation will be unattainable. This makes pension funds act in a stabilising way. From a social welfare perspective, they contribute at the time when the financial markets are volatile (extreme high or extreme low returns), whereas in normal market circumstances pension funds may occasionally deviate from their strategic asset allocation because of market timing. The resulting small return differences do not have the power to change the asset allocation in any significant way. Thus, the strategic asset allocation remains attainable and the deviation is only of a short-term nature.

We perform numerous robustness checks ${ }^{59}$ First, we use the country-specific interest rates augmented by the continental interest rate for missing values as this maximises the number of countries included. This does not change our main findings. Second, we also obtain data return data from sovereign market indices. We use different advanced and emerging market sovereign bond indices ${ }^{60}$ to have maximum coverage. Overall, we find stronger evidence of returns reversals than in our previous results. Our findings reveal reversals on the buy side when we investigate return quintiles. For the noninvestment grade portfolio, we find a destabilising effect for the $S 5-S 1$ and the $B 5-S 5$ portfolio. Please note that these results are obtained for a limited number of observations as sovereign market indices were not available for all countries, especially not for emerging and developing ones. We assume that pension funds only hold 10-year sovereign bonds as we do not have data at our disposal on the exact composition of the sovereign bond portfolios of each individual pension fund. Third, this study uses different investment moments within the month. This accounts for the possibility that differences in returns are driven by the timing of the investment. We investigate investments at the beginning, at the end, at the middle, at the middle and the end, and at the end of every week (four equal amounts), daily (20-workdays) and at payday in the Netherlands (the $25^{\text {th }}$ of every month). These alternatives have not changed our main findings, meaning that our findings are not driven by the timing of the investment moment within the month.

\section{Conclusions}

This study finds evidence of intensive herding behaviour in the sovereign bond market by 67 large Dutch pension funds between December 2008 and December 2014. These findings prove to be robust for

\footnotetext{
${ }^{59}$ Although we find evidence of a destabilizing effect of pension funds in normal market circumstances, it is important to note that prices can move away from their fundamental values for some other reasons, like inventory costs considerations or market frictions.

${ }^{60} \mathrm{We}$ use the non-hedged sovereign bond indices denominated in euros. Thus, our study also includes the returns from the exchange rate changes.
} 
numerous specifications. We find substantially higher herding behaviour in the sovereign bond market than in the equity market. Previous studies on the equity market found an Lakonishok et al. (1992) (LSV) herding measure of around 0.03 (Lakonishok et al., 1992, Grinblatt et al., 1995; Jame, 2011). This means that 53 percent trades in one direction, and 47 percent trades in the other direction. The imbalance is much larger for the sovereign bond market. The overall, buy and sell herding measures for sovereign bonds amount to $0.14,0.12$ and 0.16 , respectively. This indicates that the intensity of herding behaviour is approximately five times larger for these bonds than it is for equity investments. More importantly, sovereign bonds account for approximately $60 \%$ of the investment portfolios of Dutch pension funds. Thus, herding behaviour in these bonds may have significant consequences.

This study assesses which factors play a role in the occurrence and extent of herding behaviour. Our examination reveals that herding behaviour is mainly driven by macroeconomic factors and countryspecific financial market conditions. These findings are confirmed by our econometric analysis. In addition, the institutional setting influences herding behaviour. Institutional factors, like institutional indices, have a significant effect. To our surprise, pension fund characteristics have no significant impact on herding behaviour, which may be explained by persistence of the characteristics over time.

As the potential public welfare costs of herding are high as witnessed by the European debt crisis, we need to establish whether herding behaviour exhibited by Dutch pension funds indeed has a destabilising effect. If herding behaviour is indeed stabilising, no return reversal is expected as the purchase or sale transaction prices in new information. Our findings show mixed results on whether pension funds exhibit stabilising behaviour in the sovereign bond markets. Sell-side transactions by pension funds do have a destabilising effect. We find consistent evidence in the return quintiles that there are immediate return reversals. Sometimes these reversals persist for several months. When regarding pension funds' portfolio decisions, there are return reversals in the portfolio where it goes long in the most intensive buy herding quintile (B5) and short in the least intensive buy quintile (B1). When using sovereign market indices, we also find evidence of destabilising behaviour in other portfolios. In addition, we find evidence of stabilising and destabilising behaviour being context specific and consequently timeinconsistent. The trading behaviour of pension funds is destabilising in times of relatively normal market circumstances.

When extreme returns are not winsorised, we find that Dutch pension funds have a stabilising effect on the sovereign bond market. These different effects can be explained by the necessity to rebalance. If extreme returns are not rebalanced, the strategic asset allocation will be unattainable in the long term, whereas market timing approaches may be used in the short term when returns do not deviate too much. This enables the pension funds to attain their strategic asset allocation. Please note that stabilisation and destabilisation do not have the same social benefits and costs under different market 
circumstances. In times of crisis, the contribution that pension funds make to stabilisation has a much higher value from a welfare perspective than destabilisation during a non-crisis period. However, crisis periods are probably shorter than a non-crisis periods. The exact social benefits or costs remain subject to further research.

Our study has some limitations. Although it has high frequency data (monthly data) compared to quarterly or semi-annual data used in other studies, very short-term herding may still occur. In addition, institutional trading is most likely to distort prices if it is concentrated in short intervals (Lipson and Puckett, 2010). Consequently, our estimates potentially underestimate actual herding behaviour. Our study also investigates a very specific time frame in the European sovereign bond market. The European sovereign debt crisis and its uncertainty may have influenced pension funds' behaviour. However, it is especially useful to study these extreme times from a social welfare perspective. Herding can also be driven by different motives, and further research is needed as to whether different motives lead to different outcomes about stabilising or destabilising behaviour.

Several policy recommendations follow from our study results. First, this study reveals some factors that influence the intensity of herd behaviour. These factors can be monitored and their consequences can be taken into account by pension funds' managers and supervisors. Second, Dutch pension funds face a trade-off in terms of acquiring information and the cost of information. Numerous indicators reveal that information costs plays a crucial role in herding behaviour. For example, pension funds herd less in countries where they have large sovereign holdings. Large sovereign bond holdings are relatively cheap if there are fixed costs for country-specific investments as noted by Calvo and Mendoza (2000). Although some diversification has its merits, information costs may prompt additional herding behaviour, especially on the sell side. In general, herd behaviour seems more pronounced when information is scares and/or costly. Pension funds' managers and supervisors need to be aware of the fact that (further) diversification can have unintended consequences (e.g. more intensive herd behaviour). Third, pension fund supervisors should not treat pension fund herd behaviour as a homogeneous phenomenon. Herding behaviour contributes to stability in the sovereign bond market during crisis times. However, our study also reveals that destabilising behaviour occurs during non-crisis times. Thus monitoring of pension funds should not be limited to crisis periods. A stricter investment policy in accordance with the strategic asset allocation may limit the destabilising effect during non-crisis times. Whereas the limits of strategic asset allocation are more binding during crisis times, non-crisis times give the opportunity to engage in destabilising behaviour. 


\section{Acknowledgements}

We would like to thank Brigitte Unger for her valuable comments and suggestions, and Jack Bekooij, David Keijzer and Dirk van der Wal for their excellent research assistance. We thank the participants of the Utrecht University School of Economics seminars for their contributions, and we are grateful to the participants of the Global Academy of Business and Economic Research (GABER) conference in New York for their valuable suggestions.

\section{Bibliography}

Afonso, A., Furceri, D., \& Gomes, P. (2012). Sovereign credit ratings and financial markets linkages: Application to European data. Journal of International Money and Finance, Vol. 31, pp. 606-638.

Afonso, A., Gomes, P., \& Rother, P. (2011). Short- and long-run determinants of sovereign debt credit ratings. International Journal of Finance and Economics, Vol. 16, pp. 1-15.

Ahrend, R., \& Schwellnus, C. (2013). Do investors disproportionately shed assets of distant countries during global financial crisis? The role of increased uncertainty. OECD Journal: Economic Studies, Vol. 2012/1.

Anand, A., Irvine, P., Puckett, A., \& Venkataraman, K. (2013). Institutional trading and stock resiliency: Evidence from the 2007-2009 financial crisis. Journal of Financial Economics, Vol. 108 (2013), pp. 773-797.

Andreu, L., Ortiz, C., \& Sarto, J. L. (2014). Herding in the strategic allocations of Spanish pension plan managers. Journal of Economics and Finance, pp. 658-671.

Balagyozyan, A., \& Cakan, E. (2016). Did large institutional investors flock into the technology herd? An empirical investigation using a vector Markov-switching model. Applied Economics, Vol. 48, no. 58, pp. 5731-5747.

Banerjee, A. V. (1992). A Simple Model of Herd Behavior. Quarterly Journal of Economics, Vol. 107, no. 3 (Aug., 1992), pp. 797-817.

Baum, A., Checherita-Westphal, C., \& Rother, P. (2013). Debt and growth: New evidence for the euro area. Journal of International Money and Finance, Vol. 32, pp. 809-821.

Bengtsson, E. (2013). Fund Management and Systemic Risk - Lessons fro the Global Financial Crisis. CITYPERC Working Paper Series, No. 2013/06.

Bennett, J. A., Sias, R. W., \& Starks, L. T. (2003). Greener Pastures and the Impact of Dynamic Institutional Preferences. The Review of Financial Studies, Vol. 16, No. 4, pp. 1203-1238.

Bijlsma, M., \& Vermeulen, R. (2015). Insurance companies' trading behaviour during the European sovereign debt crisis: Flight home or flight to quality? DNB Working Paper, No. 468. 
Bikhchandani, S., \& Sharma, S. (2000). Herd Behavior in Financial Markets: A Review. IMF Working Paper, WP/00/48.

Bikhchandani, S., Hirshleifer, D., \& Welch, I. (1992). A theory of fads, fashion, custom, and cultural change as informational cascades. Journal of Political Economy, Vol. 100, no. 3, pp. 709-730.

Bikker, J.A., Broeders, D., \& de Dreu, J. (2010). Stock Market Performance and Pension Fund Investment Policy: Rebalancing, Free Float, or Market Timing? International Journal of Central Banking, Vol. 6, No. 2, pp. 53-79.

Bikker, J.A., Spierdijk, L., \& Sluis, P. J. (2007). Market impact costs of institutional equity trades. Journal of International Money and Finance, Vol. 26, no. 6, pp. 974-1000.

Borensztein, E. R., \& Gelos, R. G. (2000). A Panic-Prone Pack? The Behavior of Emerging Market Mutual Funds. IMF Working Paper, WP/00/198.

Broeders, D., Chen, D., Minderhoud, P., \& Schudel, W. (2016). Pension funds' herding. DNB Working Paper, No. 503, February 2016.

Cai, F., Han, S., \& Li, D. (2012). Institutional Herding in the Corporate Bond Market. Board of Governors of the Federal Reserve System International Finance Discussion Papers, no. 1071.

Calvo, G. A., \& Mendoza, E. G. (2000). Rational contagion and the globalization of securities markets. Journal of International Economics, Vol. 51, pp. 79-113.

Cassimon, D., Moreno-Dodson, B., \& Wodon, Q. (2008). Debt sustainability for Low-Income Countries: A review of standard and alternative concepts. MPRA paper.

Chang, E. C., Cheng, J. W., \& Khorana, A. (2000). An examination of herd behavior in equity markets: An international perspective. Journal of Banking \& Finance, Vol. 24, pp. 1651-1679.

Choe, H., Kho, B.-C., \& Stulz, R. M. (1999). Do foreign investors destabilize stock markets? The Korean experience in 1997. Journal of Financial Economics, Vol. 54, pp. 227-264.

Choi, N., \& Skiba, H. (2015). Institutional herding in international markets. Journal of Banking \& Finance, Vol. 55, pp 246-259.

Choi, N., Fedenia, M., Skiba, H., \& Sokolyk, T. (2017). Portfolio concentration and performance of institutional investors worldwide. Journal of Financial Economics, Vol. 123, no. 1, January 2017, pp. 189-208.

Christie, W. G., \& Huang, R. D. (1995). Following the Pied Piper: Do Individual Returns Herd around the Market? Financial Analysts Journal, Vol. 51, no. 4 (Jul.-Aug., 1995), pp. 31-37.

Cooper, A., Day, T., \& Lewis, C. (2001). Following the leader: a study of individual analysts' earnings forecasts. Journal of Financial Economics, Vol. 61, pp. 383-416.

Da, Z., Larrain, B., Sialm, C., \& Tessada, J. (2015). Price pressure from coordinated noise trading: Evidence from pension fund reallocations. April 2015. 
Dasgupta, A., Prat, A., \& Verardo, M. (2011). Institutional Trade Persistence and Long-Term Equity Returns. Journal of Finance, Vol. 66, no. 2.

de Haan, L., \& Kakes, J. (2011). Momentum or contrarian investment strategies: Evidence from Dutch institutional investors. Journal of Banking \& Finance, vol. 35, No. 9, pp. 2245-2251.

De Nederlandsche Bank. (2015). Macroeconomic statistics pension funds. Retrieved: July 31, 2015.

Devenow, A., \& Welch, I. (1996). Rational herding in financial economics. European Economic Review, Vol. 40, pp. 603-615.

Economou, F., Gavriilidis, K., Kallinterakis, V., \& Yordanov, N. (2015). Do Fund Managers Herd in Fronties Markets - and Why? International Review of Financial Analysis.

Economou, F., Kostakis, A., \& Philippas, N. (2011). Cross-country effects in herding behaviour: Evidence from four south European markets. Journal of International Financial Markets, Institutions \& Money, Vol. 21 (2011), pp. 443-460.

Falkenstein, E. G. (1996). Preferences for Stock Characteristics As Revealed by Mutual Fund Portfolio Holdings. Journal of Finance, Vol. 51, no. 1, pp. 111-135.

Frey, S., Herbst, P., \& Walter, A. (2014). Measuring mutual fund herding - A structural approach. Journal of International Financial Markets, Institutions \& Money, pp. 219-239.

Froot, K. A., Scharfstein, D. S., \& Stein, J. C. (1992). Herd on the street: Informational inefficiencies in a market with short-term speculation. Journal of Finance, Vol. 47, no. 4, pp. 1461-1484.

Galariotis, E. C., Rong, W., \& Spyrou, S. I. (2015). Herding on fundamental information: A comparative study. Journal of Banking \& Finance, Vol. 50 (2015), pp. 589-598.

Gande, A., \& Parsley, D. (2014). Sovereign Credit Ratings, Transparency and International Portfolio Flows. HKIMR Working Paper, No. 12/2014.

Gelos, G. R., \& Wei, S.-J. (2005). Transparency and International Portfolio Holdings. Journal of Finance, Vol. 60, No. 6 (Dec., 2005), pp. 2987-3020.

Goldstein, I., \& Pauzner, A. (2004). Contagion of self-fulfilling financial crises due to diversification of investment portfolios. Journal of Economic Theory, Vol. 119, pp. 151-183.

Granger, C. (1998). Extracting information from mega-panels and high-frequency data. Statistica Neerlandica, Vol. 52, no. 3, pp.258-272.

Grinblatt, M., Titman, S., \& Wermers, R. (1995). Momentum Investment Strategies, Portfolio Performance, and Herding: A Study of Mutual Fund Behavior. American Economic Review, Vol. 85, no. 5 (Dec., 1995), pp. 1088-1105.

Harris, R., \& Tzavalis, E. (1999). Inference for unit roots in dynamic panels where the time dimension is fixed. Journal of Econometrics, Vol. 91, No. 2, August 1999, pp. 201-226. 
Hirshleifer, D., Subrahmanyam, A., \& Titman, S. (1994). Security analysis and trading patterns when some investors receive information before others. Journal of Finance, Vol. 49, no. 5, pp. 16651698.

Holmes, P., Kallinterakis, V., \& Leite Ferreira, M. (2013). Herding in a Concentrated Market: a Question of Intent. European Financial Management, Vol. 19, No. 3, pp. 497-520.

Hsieh, M.-F., Yang, T.-Y., Yang, Y.-T., \& Lee, J.-S. (2011). Evidence of herding and positive feedback trading for mutual funds in emerging Asian countries. Quantitative Finance, Vol. 11, Issue 3, pp. 423-435.

Hwang, S., \& Salmon, M. (2004). Market stress and herding. Journal of Empirical Finance, Vol. 11, no. 4, pp. 585-616.

Im, K., Pesaran, M., \& Shin, Y. (2003). Testing for unit roots in heterogeneous panels. Journal of Econometrics, Vol. 115, No. 1, July 2003, pp. 53-74.

International Monetary Fund. (2014). Chapter 2: How do changes in the investor base and financial deepening affect emerging market economies? In International Monetary Fund, Global Financial Stability Report: Moving from Liquidity to Growth-Driven Markets (pp. 67-99). Washington.

Jame, R. (2011). Pension Fund Herding and Stock Returns.

Jones, B. (2015). Assets Bubbles: Re-thinking Policy for the Age of Asset Management. IMF Working Paper, WP/15/27.

Kaminsky, G. L., \& Reinhart, C. M. (2000). On crises, contagion, and confusion. Journal of International Economics, Vol. 51, Issue 1, pp. 145-168.

Kaminsky, G., Lyons, R. K., \& Schmukler, S. L. (2004). Managers, investors, and crises: mutual fund strategies in emerging markets. Journal of International Economics, Vol. 64 (2004), pp. 113-134.

Kim, S.-H., \& Lee, K. (2014). Determinants of Short-term Institutional Trading during Tranquil and Crisis Times. KAIST Business School Working Paper Series, KCB-WP-2014-013.

Kim, W., \& Wei, S.-J. (2002). Foreign portfolio investors before and during a crisis. Journal of International Economics, Vol. 56 (2002), pp. 77-96.

Koetsier, I., \& Bikker, J.A. (2017). Asset-class herd behavior of Dutch pension funds. DNB Working Paper, De Nederlandsche Bank, Amsterdam (forthcoming).

Lakonishok, J., Shleifer, A., \& Vishny, R. W. (1992). The impact of institutional trading on stock prices. Journal of Financial Economics, Vol. 32, pp. 23-43.

Lipson, M., \& Puckett, A. (2010). Institutional Trading During Extreme Market Movements. March 2010.

Lobão, J., \& Serra, A. P. (2002). Herding Behavior - Evidence from Portuguese Mutual Funds. 
Melecky, M., \& Raddatz, C. (2015). Fiscal Responses after Catastrophes and the Enabling Role of Financial Development. World Bank Economic Review, Vol. 29, no. 1, pp. 129-149.

Nofsinger, J. R., \& Sias, R. W. (1999). Herding and Feedback Trading by Institutional and Individual Investors. Journal of Finance, Vol. 54, No. 6 (Dec., 1999), pp. 2263-2295.

Pesaran, M. (2007). A simple panel unit root test in the presence of cross-section dependence. Journal of Applied Econometrics, Vol. 22, No. 2, March 2007, pp. 265-312.

Puckett, A., \& Yan, X. (2008). Short-term Institutional Herding and Its Impact on Stock Prices.

Raddatz, C., \& Schmukler, S. L. (2012). On the international transmission of shocks: Micro-evidence from mutual fund portfolios. Journal of International Economics, Vol. 88 (2012), pp. 357-374.

Raddatz, C., \& Schmukler, S. L. (2013). Deconstructing Herding: Evidence from Pension Fund Investment Behavior. Journal of Financial Services Research, Vol. 43, pp. 99-126.

Rajan, R. G. (2006). Has Finance Made the World Riskier? European Financial Management, Vol. 12, No. 4, pp. 499-533.

Reinhart, C. M., \& Rogoff, K. S. (2009). This Time is Different: Eight Centuries of Financial Folly. Princeton University Press.

Scharfstein, D. S., \& Stein, J. C. (1990). Herd behavior and investment. American Economic Review, Vol. 80, no. 3, pp. 465-479.

Sias, R. W. (2004). Institutional Herding. Review of Financial Studies, Vol. 17, No. 1 (Spring, 2004), pp. 165-206.

Trueman, B. (1994). Analyst Forecasts and Herding Behavior. The Review of Financial Studies, Vol. 7, No. 1, pp. 97-124.

van der Smitte, J. (2013). Short introduction to the pension system in the Netherlands. Ministry of Social Affairs and Employment.

Voronkova, S., \& Bohl, M. T. (2005). Institutional Traders' Behavior in an Emerging Stock Market: Empirical Evidence on Polish Pension Fund Investors. Journal of Business Finance \& Accounting, Vol. 32, no. 7 \& 8, pp. 1537-1560.

Wermers, R. (1999). Mutual Fund Herding and the Impact on Stock Prices. Journal of Finance, Vol. 54, No. 2 (Apr., 1999), pp. 581-622.

Wylie, S. (2005). Fund Manager Herding: A Test of the Accuracy of Empirical Results Using U.K. Data. Journal of Business, Vol. 78, no. 1 (January 2005), pp. 381-403.

Xiao, J. (2015). Domestic and Foreign Mutual Funds in Mexico: Do They Behave Differently? IMF Working Paper, WP/15/104. 
Xiao, Y. (2007). What do bond holdings reveal about international funds' preferences? Emerging Markets Review, Vol. 8 (2007), pp. 167-180.

\section{APPENDICES}

\subsection{Methodology appendix}

The adjustment factor assures that the LSV herding measure does not overestimate herd behaviour. Equation (9) shows the formula for the adjustment factor.

$$
A F_{i t}=E\left[\left|p_{i t}-p_{t}\right|\right]
$$

Equation (10) shows that $N_{i t}$ is the number of pension trading in county ( $i$ ) and month $(t) \cdot p_{t}$ is the proportion of Dutch pension funds buying long-term sovereign bonds in a particular month. $B_{i t}$ is the number of pension funds that are purchasing long-term sovereign bonds in country $(i)$. We use $N_{i t}, B_{i t}$ and $p_{t}$ to calculate the expected outcomes of the adjustment factor. The outcomes are expected to follow a binominal distribution, and Equation (11) shows how to calculate the probability of occurrence.

$$
\begin{gathered}
N_{i t}=B_{i t}+S_{i t} \\
b\left[N_{i t} ; B_{i t}, p_{t}\right]=\left(\begin{array}{c}
N_{i t} \\
B_{i t}
\end{array}\right) p_{t}^{B_{i t}}\left[1-p_{t}\right]^{N_{i t}-B_{i t}}
\end{gathered}
$$

The adjustment factor is the sum of all outcomes times the probability of occurrence. Table 1 shows a numerical example of such a calculation. We assume that $p_{t}$ is equal to 0.3 and there are five trades. The reasons for this choice is that it allows us to show two extreme cases of the LSV herding measure (a negative LSV herding measure and a LSV herding measure over 0.5 ).

Table 1. Results of the adjustment factor calculations

\begin{tabular}{lllll}
\hline & $b\left[N_{i t} ; B_{i t}, p_{t}\right]$ & $\frac{B_{i t}}{N_{i+}}$ & $p_{t}$ & $\left|p_{i t}-p_{t}\right|$ \\
\hline 0 & 0.168 & 0 & 0.3 & 0.050 \\
1 & 0.360 & 0.2 & 0.3 & 0.036 \\
2 & 0.309 & 0.4 & 0.3 & 0.031 \\
3 & 0.132 & 0.6 & 0.3 & 0.040 \\
4 & 0.028 & 0.8 & 0.3 & 0.014 \\
5 & 0.002 & 1 & 0.3 & 0.002 \\
\hline
\end{tabular}


The finale step is to sum the column $\left|p_{i t}-p_{t}\right|$, these are the outcomes for a specific number of buy transactions. The adjustment factor is equal to 0.173 . We calculate the LSV herding measure $\left(H M_{i t}\right)$ for the different number of buys $\left(B_{i t}\right)$. Our findings are presented below. Our results reveal that the LSV herding measure can be negative if it is close to $p_{t}$. Furthermore, the herding measure can be over 0.5 if $p_{t}$ is relatively low or high.

Table 2. LSV herding measure for different proportion of buys

\begin{tabular}{ll}
\hline$\frac{B_{i t}}{N_{i t}}$ & $H M_{i t}$ \\
\hline 0 & 0.13 \\
0.2 & -0.07 \\
0.4 & -0.07 \\
0.6 & 0.13 \\
0.8 & 0.33 \\
1 & 0.53 \\
\hline
\end{tabular}




\subsection{Results appendix}

Table 3. Summary statistics of pension fund, macroeconomic, financial and institutional indicators

\begin{tabular}{|c|c|c|c|c|c|}
\hline & Observations & Mean & Std. Dev. & Min & Max \\
\hline Lagged logarithm of total holdings & 55635 & 15.94 & 1.03 & 13.67 & 19.64 \\
\hline Lagged funding ratio & 55655 & 1.09 & 0.13 & 0.77 & 1.57 \\
\hline Lagged relative returns by sovereign & 55635 & 0.23 & 5.73 & -45.82 & 36.40 \\
\hline Lagged relative performance fixed-interest investments & 55611 & 0.73 & 1.28 & -7.26 & 13.37 \\
\hline Lagged distance to the SAA & 55635 & 0.22 & 0.23 & 0.00 & 3.53 \\
\hline Lagged risk preference & 53016 & 0.72 & 0.40 & 0.07 & 4.08 \\
\hline Lagged percentage of sovereign holding & 58093 & 0.05 & 0.11 & 0.00 & 1.00 \\
\hline Inflation & 60622 & 1.94 & 2.58 & -6.60 & 30.37 \\
\hline Current account & 60605 & -0.52 & 6.55 & -38.10 & 32.60 \\
\hline Exchange rate, change & 57742 & 0.11 & 2.18 & -11.08 & 67.98 \\
\hline GDP growth & 60605 & 1.21 & 3.30 & -13.10 & 17.66 \\
\hline General government debt & 60399 & 61.94 & 32.86 & 4.46 & 244.90 \\
\hline Logarithm of the sovereign bond market & 38538 & 26.31 & 1.81 & 17.81 & 30.48 \\
\hline Unemployment rate & 56109 & 8.53 & 4.74 & 0.45 & 33.29 \\
\hline Net government lending & 60605 & -3.68 & 4.41 & -32.42 & 20.49 \\
\hline Credit rating & 59351 & 7.08 & 5.10 & 1.00 & 22.00 \\
\hline Credit outlook & 59351 & -0.20 & 0.52 & -1.00 & 1.00 \\
\hline Stock market return & 51979 & 0.81 & 6.47 & -37.38 & 51.49 \\
\hline VIX index & 60626 & 20.91 & 8.29 & 11.40 & 46.35 \\
\hline Yield & 51609 & 5.67 & 4.05 & 0.40 & 65.60 \\
\hline Long-term interest rate & 42278 & 4.53 & 3.35 & 0.00 & 29.20 \\
\hline Logarithm of the CDS spread & 52205 & 4.71 & 1.07 & 2.10 & 9.61 \\
\hline Credit rating change in the past 3 months & 59351 & -0.05 & 0.45 & -6.00 & 6.00 \\
\hline Credit outlook change in the past 3 months & 59351 & 0.00 & 0.36 & -2.00 & 2.00 \\
\hline Control of corruption & 60626 & 0.57 & 1.07 & -1.57 & 2.52 \\
\hline Government effectiveness & 60626 & 0.69 & 0.90 & -1.26 & 2.27 \\
\hline Political stability and absence of violence/terrorism & 60626 & 0.23 & 0.87 & -2.81 & 1.49 \\
\hline Regulatory quality & 60626 & 0.71 & 0.84 & -1.81 & 2.23 \\
\hline Rule of law & 60626 & 0.58 & 1.03 & -1.89 & 2.12 \\
\hline Voice and accountability & 60624 & 0.61 & 0.84 & -1.66 & 1.76 \\
\hline
\end{tabular}

Table 4. Summary statistic of the balance of payments statistics (EUR 1,000)

\begin{tabular}{llllll}
\hline & Observations & Mean & Std. Dev. & Min & Max \\
\hline Sovereign holdings, beginning of the month & 60626 & 131344 & 532933 & -54460 & 14059790 \\
Purchases and sales & 60626 & 856 & 55801 & -5646480 & 2976569 \\
Price changes & 60626 & 491 & 13981 & -530300 & 675254 \\
Exchange rate changes & 60626 & -9 & 2495 & -198219 & 205988 \\
Other changes & 60626 & 6 & 3856 & -188948 & 524694 \\
Sovereign holdings, end of the month & 60626 & 132688 & 537948 & -121117 & 14059790 \\
\hline
\end{tabular}


Figure 1. Density of the LSV herding measure with a minimum of five trades between December 2008 and December 2014

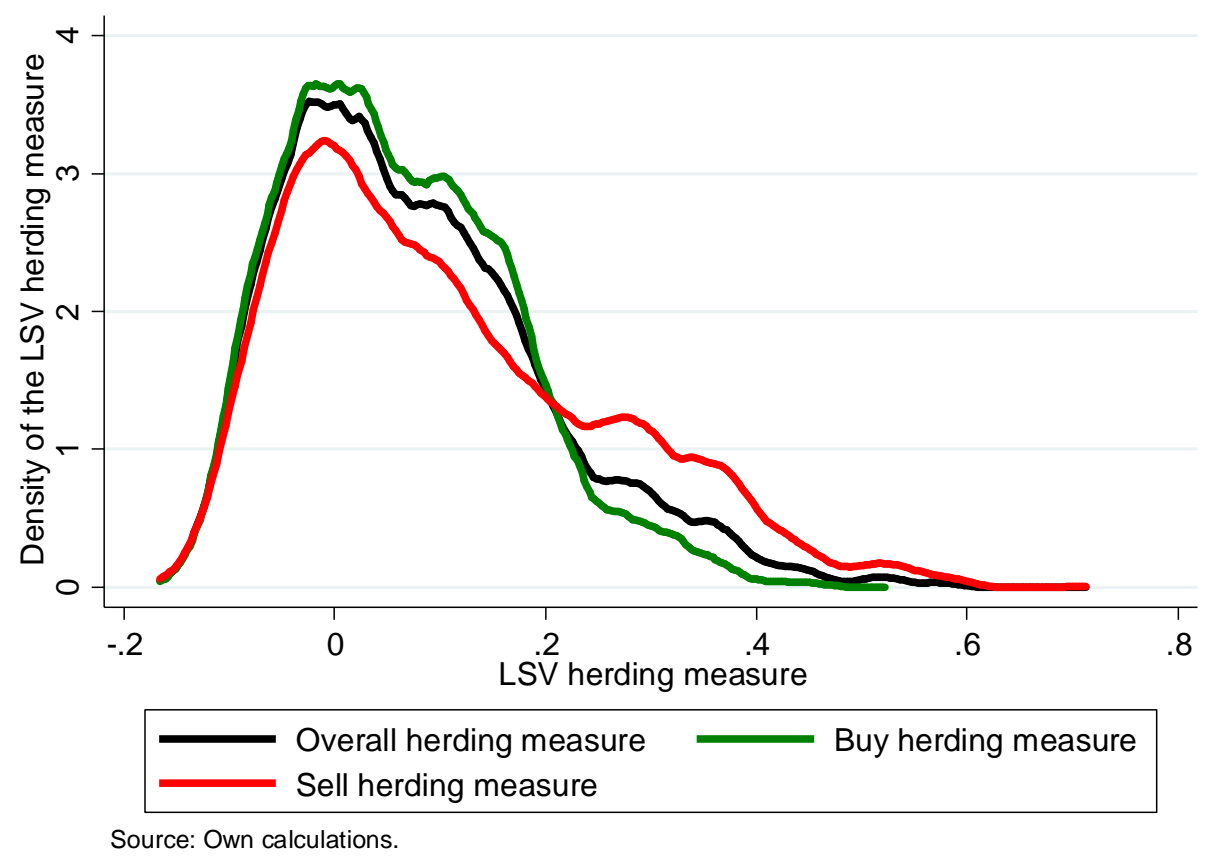

Figure 2. Density of the LSV herding measure with a minimum of five trades adjusted by the country-specific interest rate between December 2008 and December 2014

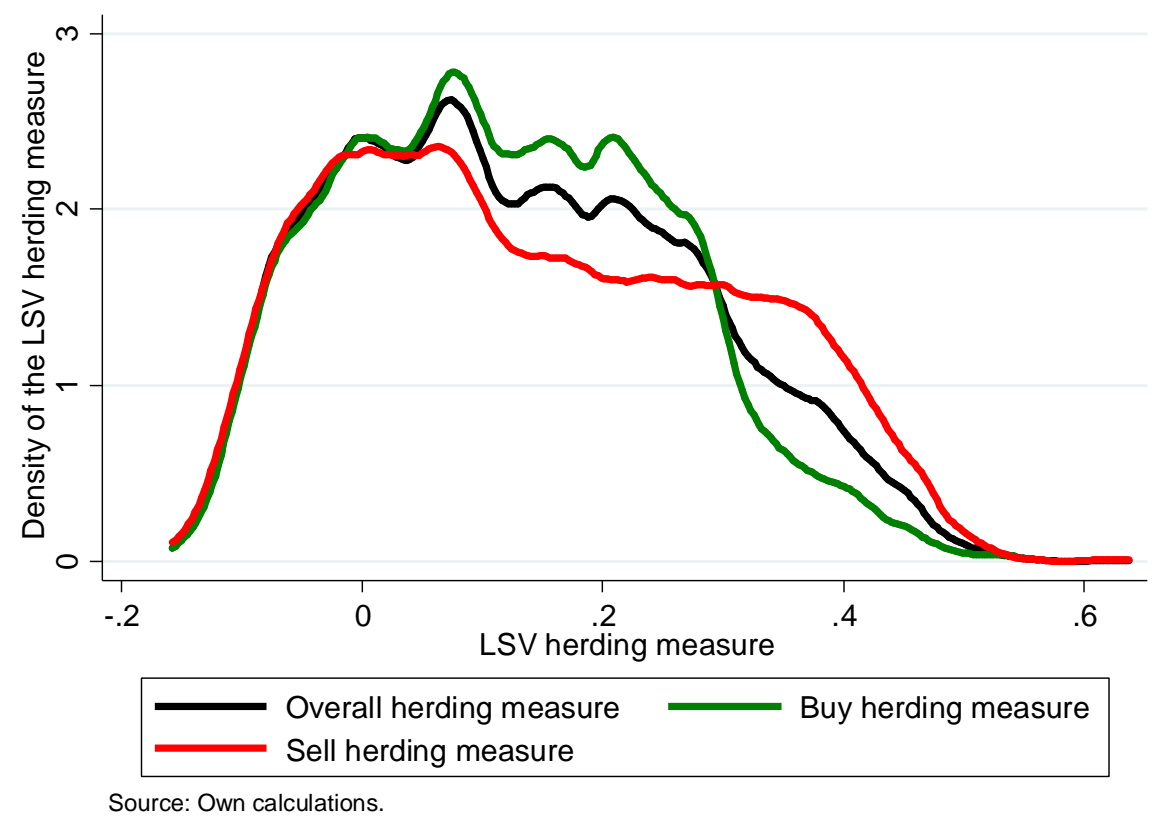


Figure 3. Distribution of investments across countries between December 2008 and December 2014

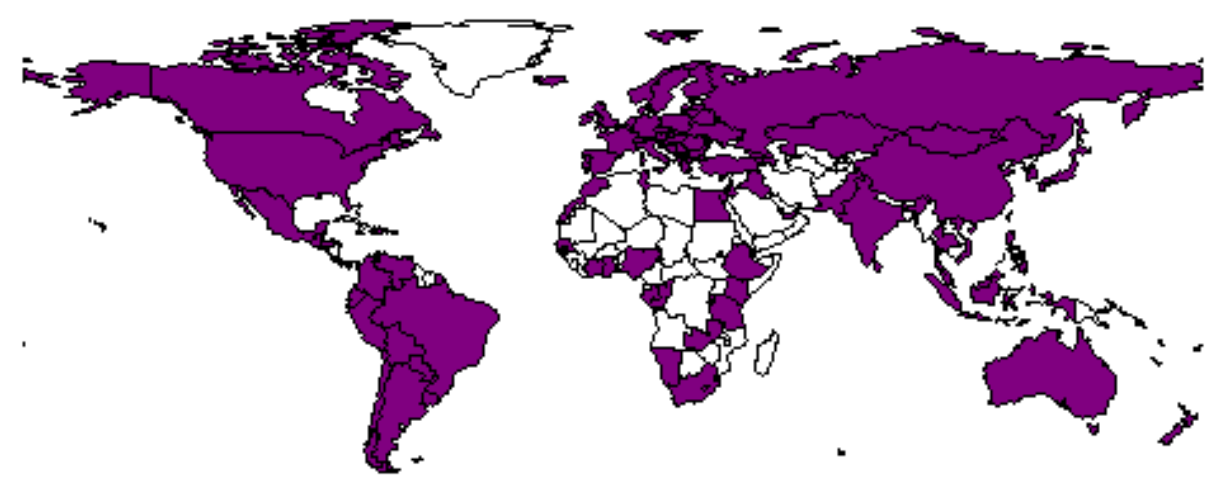

Figure 4. Average size of total pension fund holdings between December 2008 and December 2014

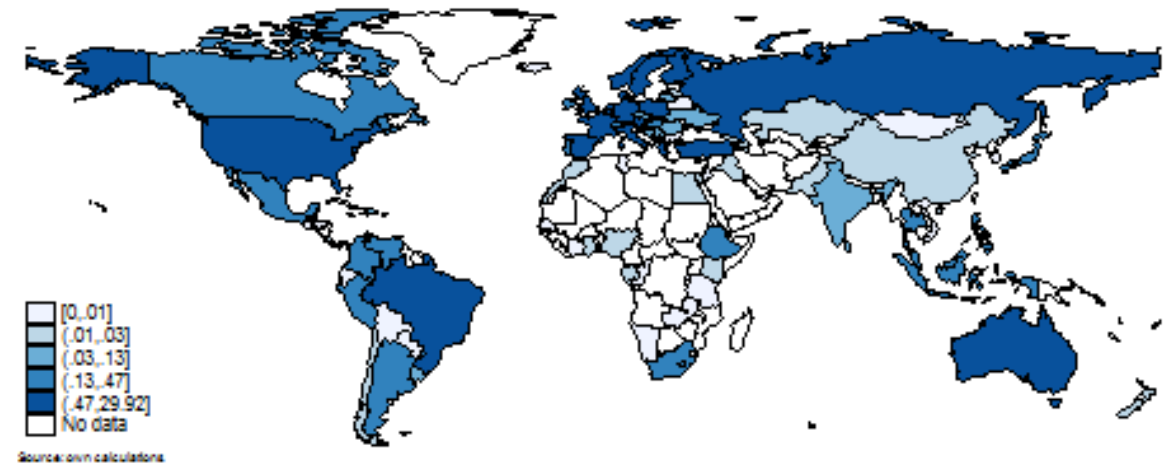


Table 5. Summary statistics of the herding measure adjusted for accrued interest

\begin{tabular}{llllll}
\hline \multicolumn{6}{l}{ Herding measure adjusted by the prevailing interest rate } \\
\hline & Observations & Mean & Std. Dev. & Min & Max \\
\hline Overall herding measure & 41643 & 0.14 & 0.15 & -0.25 & 0.64 \\
Buy herding measure & 24058 & 0.12 & 0.13 & -0.25 & 0.54 \\
Sell herding measure & 17585 & 0.16 & 0.17 & -0.25 & 0.64 \\
\hline
\end{tabular}

Herding measure adjusted by the prevailing interest rate augmented with WEO countrygroups average interest rates

\begin{tabular}{llllll}
\hline & Observations & Mean & Std. Dev. & Min & Max \\
\hline Overall herding measure & 48407 & 0.09 & 0.14 & -0.25 & 0.69 \\
Buy herding measure & 26184 & 0.08 & 0.12 & -0.24 & 0.52 \\
Sell herding measure & 22223 & 0.11 & 0.15 & -0.25 & 0.69 \\
\hline
\end{tabular}

Herding measure adjusted by the prevailing interest rate and position continuing trades

\begin{tabular}{llllll}
\hline & Observations & Mean & Std. Dev. & Min & Max \\
\hline Overall herding measure & 18120 & 0.10 & 0.16 & -0.25 & 0.73 \\
Buy herding measure & 7963 & 0.16 & 0.19 & -0.23 & 0.73 \\
Sell herding measure & 10157 & 0.06 & 0.12 & -0.25 & 0.59 \\
\hline
\end{tabular}

Herding measure adjusted by the prevailing interest rate augmented with WEO countrygroups average interest rates and position continuing trades

\begin{tabular}{llllll}
\hline & Observations & Mean & Std. Dev. & Min & Max \\
\hline Overall herding measure & 20451 & 0.10 & 0.16 & -0.24 & 0.72 \\
Buy herding measure & 9570 & 0.12 & 0.18 & -0.24 & 0.72 \\
Sell herding measure & 10881 & 0.08 & 0.14 & -0.24 & 0.69 \\
\hline
\end{tabular}


Table 6. Trading intensity and the herding measure adjusted for accrued interest

\begin{tabular}{|c|c|c|c|c|c|}
\hline \multicolumn{6}{|c|}{ Herding measure adjusted for the prevailing interest rate } \\
\hline \multicolumn{6}{|l|}{ Overall herding measure } \\
\hline & Observations & Mean & Std. Dev. & Min & $\overline{M a x}$ \\
\hline A minimum of 3 trades & 40048 & 0.14 & 0.15 & -0.20 & 0.64 \\
\hline A minimum of 5 trades & 37204 & 0.13 & 0.15 & -0.16 & 0.64 \\
\hline A minimum of 10 trades & 28419 & 0.11 & 0.13 & -0.12 & 0.54 \\
\hline A minimum of 15 trades & 18492 & 0.11 & 0.12 & -0.10 & 0.53 \\
\hline \multicolumn{6}{|l|}{ Buy herding measure } \\
\hline & Observations & Mean & Std. Dev. & Min & Max \\
\hline A minimum of 3 trades & 23750 & 0.12 & 0.13 & -0.20 & 0.54 \\
\hline A minimum of 5 trades & 22887 & 0.12 & 0.13 & -0.16 & 0.54 \\
\hline A minimum of 10 trades & 19422 & 0.12 & 0.12 & -0.12 & 0.54 \\
\hline A minimum of 15 trades & 14250 & 0.13 & 0.12 & -0.10 & 0.47 \\
\hline \multicolumn{6}{|l|}{ Sell herding measure } \\
\hline & Observations & Mean & Std. Dev. & Min & $\overline{M a x}$ \\
\hline A minimum of 3 trades & 16298 & 0.16 & 0.17 & -0.19 & 0.64 \\
\hline A minimum of 5 trades & 14317 & 0.15 & 0.17 & -0.16 & 0.64 \\
\hline A minimum of 10 trades & 8997 & 0.09 & 0.14 & -0.11 & 0.53 \\
\hline A minimum of 15 trades & 4242 & 0.05 & 0.10 & -0.09 & 0.53 \\
\hline
\end{tabular}

Herding measure adjusted for the prevailing interest rate augmented with WEO countrygroups average interest rates

Overall herding measure

\begin{tabular}{llllll}
\hline & Observations & Mean & Std. Dev. & Min & Max \\
\hline A minimum of 3 trades & 46842 & 0.10 & 0.14 & -0.20 & 0.69 \\
A minimum of 5 trades & 44043 & 0.10 & 0.13 & -0.16 & 0.69 \\
A minimum of 10 trades & 33101 & 0.09 & 0.12 & -0.12 & 0.60 \\
A minimum of 15 trades & 19307 & 0.08 & 0.11 & -0.10 & 0.60 \\
\hline
\end{tabular}

Buy herding measure

\begin{tabular}{llllll}
\hline & Observations & Mean & Std. Dev. & Min & Max \\
\hline A minimum of 3 trades & 25345 & 0.09 & 0.12 & -0.20 & 0.52 \\
A minimum of 5 trades & 23895 & 0.09 & 0.12 & -0.16 & 0.52 \\
A minimum of 10 trades & 18507 & 0.09 & 0.11 & -0.12 & 0.52 \\
A minimum of 15 trades & 12508 & 0.10 & 0.10 & -0.10 & 0.44 \\
\hline
\end{tabular}

Sell herding measure

\begin{tabular}{llllll}
\hline & Observations & Mean & Std. Dev. & Min & Max \\
\hline A minimum of 3 trades & 21497 & 0.11 & 0.15 & -0.19 & 0.69 \\
A minimum of 5 trades & 20148 & 0.11 & 0.15 & -0.16 & 0.69 \\
A minimum of 10 trades & 14594 & 0.09 & 0.13 & -0.12 & 0.60 \\
A minimum of 15 trades & 6799 & 0.07 & 0.12 & -0.10 & 0.60 \\
\hline
\end{tabular}


Table 7. Trading intensity and the herding measure adjusted for accrued interest and position continuing trades

Herding measure corrected by the prevailing interest rate and position continuing trades

Overall herding measure

\begin{tabular}{llllll}
\hline & Observations & Mean & Std. Dev. & Min & Max \\
\hline A minimum of 3 trades & 15893 & 0.12 & 0.16 & -0.20 & 0.73 \\
A minimum of 5 trades & 12705 & 0.12 & 0.16 & -0.16 & 0.73 \\
A minimum of 10 trades & 5156 & 0.13 & 0.15 & -0.11 & 0.67 \\
A minimum of 15 trades & 2422 & 0.14 & 0.15 & -0.07 & 0.52 \\
\hline
\end{tabular}

Buy herding measure

\begin{tabular}{llllll}
\hline & Observations & Mean & Std. Dev. & Min & Max \\
\hline A minimum of 3 trades & 7468 & 0.16 & 0.19 & -0.20 & 0.73 \\
A minimum of 5 trades & 6411 & 0.16 & 0.18 & -0.15 & 0.73 \\
A minimum of 10 trades & 3260 & 0.16 & 0.17 & -0.10 & 0.67 \\
A minimum of 15 trades & 1562 & 0.16 & 0.17 & -0.07 & 0.52 \\
\hline
\end{tabular}

Sell herding measure

\begin{tabular}{llllll}
\hline & Observations & Mean & Std. Dev. & Min & Max \\
\hline A minimum of 3 trades & 8425 & 0.08 & 0.11 & -0.20 & 0.59 \\
A minimum of 5 trades & 6294 & 0.08 & 0.11 & -0.16 & 0.59 \\
A minimum of 10 trades & 1896 & 0.07 & 0.11 & -0.11 & 0.50 \\
A minimum of 15 trades & 860 & 0.10 & 0.10 & -0.07 & 0.39 \\
\hline
\end{tabular}

Herding measure adjusted for the prevailing interest rate augmented with WEO countrygroups average interest rates and position continuing trades

Overall herding measure

\begin{tabular}{llllll}
\hline & Observations & Mean & Std. Dev. & Min & Max \\
\hline A minimum of 3 trades & 18177 & 0.10 & 0.16 & -0.20 & 0.71 \\
A minimum of 5 trades & 14615 & 0.11 & 0.16 & -0.17 & 0.71 \\
A minimum of 10 trades & 5301 & 0.12 & 0.15 & -0.11 & 0.65 \\
A minimum of 15 trades & 2422 & 0.13 & 0.15 & -0.09 & 0.54 \\
\hline
\end{tabular}

Buy herding measure

\begin{tabular}{llllll}
\hline & Observations & Mean & Std. Dev. & Min & Max \\
\hline A minimum of 3 trades & 8608 & 0.12 & 0.17 & -0.20 & 0.71 \\
A minimum of 5 trades & 7050 & 0.12 & 0.17 & -0.17 & 0.71 \\
A minimum of 10 trades & 2825 & 0.14 & 0.15 & -0.11 & 0.65 \\
A minimum of 15 trades & 1299 & 0.14 & 0.15 & -0.09 & 0.44 \\
\hline
\end{tabular}

Sell herding measure

\begin{tabular}{llllll}
\hline & Observations & Mean & Std. Dev. & Min & Max \\
\hline A minimum of 3 trades & 9569 & 0.09 & 0.14 & -0.20 & 0.69 \\
A minimum of 5 trades & 7565 & 0.09 & 0.14 & -0.17 & 0.69 \\
A minimum of 10 trades & 2476 & 0.09 & 0.14 & -0.11 & 0.65 \\
A minimum of 15 trades & 1123 & 0.11 & 0.15 & -0.08 & 0.54 \\
\hline
\end{tabular}


Figure 5. Buy herding measure by country between December 2008 and December 2014

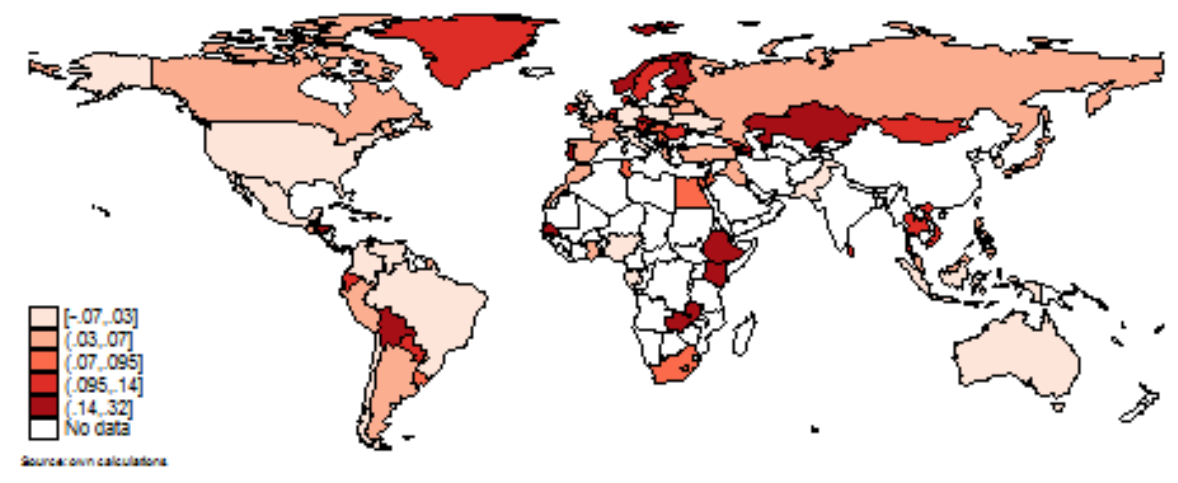

Figure 6. Sell herding measure by country between December 2008 and December 2014

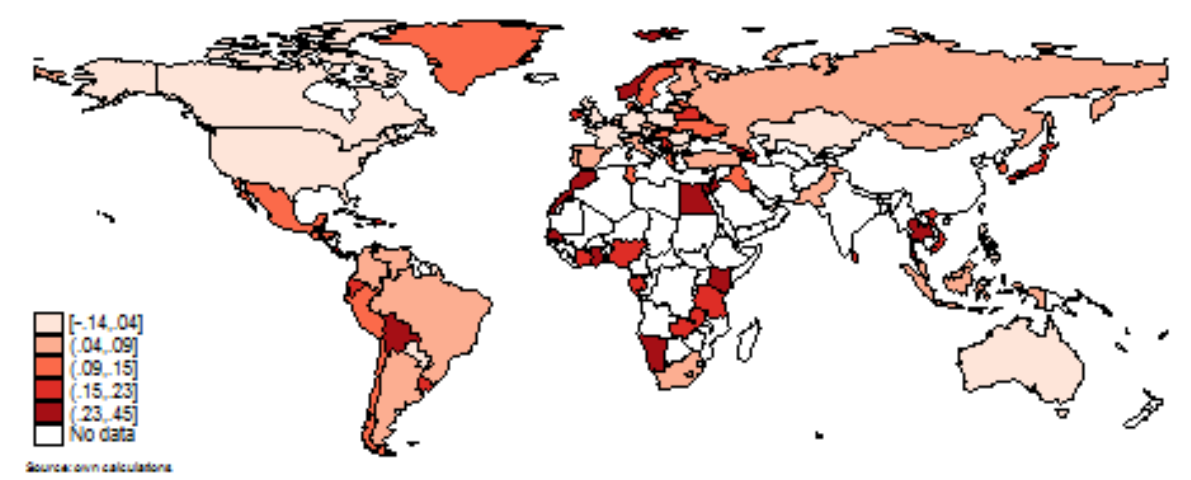




\section{Table 8. The relation between herd behaviour and safe havens and crisis countries}

This table reveal the overall, buy and sell herding measure for safe havens and crisis countries. This study limits the period of the European debt crisis to the period May 2010-July 2012. The European debt crisis starts with the first bail-out for Greece, whereas it ends with the remarks from Mario Draghi in July 2012. He would do, "whatever it takes".

\begin{tabular}{|c|c|c|c|c|c|c|}
\hline & $\begin{array}{l}\text { Safe } \\
\text { havens (1) }\end{array}$ & $\begin{array}{l}\text { Safe } \\
\text { havens (2) }\end{array}$ & $\begin{array}{l}\text { Safe } \\
\text { havens (3) }\end{array}$ & PIIGS & $\begin{array}{l}\text { Financial } \\
\text { aid } \\
\text { recipients }\end{array}$ & $\begin{array}{l}\text { Rescue } \\
\text { package } \\
\text { recipients }\end{array}$ \\
\hline \multicolumn{7}{|c|}{ Entire sample period, December 2008-December 2014} \\
\hline Overall herding & 0.13 & 0.13 & 0.14 & 0.10 & 0.11 & 0.13 \\
\hline Buy herding & 0.14 & 0.14 & 0.15 & 0.10 & 0.10 & 0.13 \\
\hline Sell herding & 0.03 & 0.04 & 0.06 & 0.09 & 0.11 & 0.13 \\
\hline \multicolumn{7}{|c|}{ European debt crisis, May 2010-July 2012} \\
\hline Overall herding & 0.13 & 0.14 & 0.15 & 0.12 & 0.14 & 0.20 \\
\hline Buy herding & 0.15 & 0.15 & 0.16 & 0.07 & 0.03 & 0.04 \\
\hline Sell herding & 0.02 & 0.03 & 0.06 & 0.15 & 0.18 & 0.24 \\
\hline Definition & \multicolumn{6}{|c|}{ Countries included } \\
\hline Safe havens (1) & \multicolumn{6}{|c|}{ Finland, Germany, the Netherlands, Switzerland } \\
\hline Safe havens (2) & \multirow{2}{*}{\multicolumn{6}{|c|}{$\begin{array}{l}\text { Austria, Finland, Germany, the Netherlands, Switzerland } \\
\text { Austria, Denmark, Finland, Germany, the Netherlands, Norway, Sweden, } \\
\text { Switzerland }\end{array}$}} \\
\hline Safe havens (3) & & & & & & \\
\hline PIIGS & \multicolumn{6}{|c|}{ Cyprus, Greece, Ireland, Italy, Portugal, Spain } \\
\hline Financial aid recipients & \multicolumn{6}{|c|}{ Cyprus, Greece, Ireland, Portugal, Spain } \\
\hline Rescue package recipients & \multicolumn{6}{|c|}{ Cyprus, Greece, Ireland, Portugal } \\
\hline
\end{tabular}




\section{Table 9. Quintile analysis using the prevailing interest rate}

We form quintiles for the indicators. These are divided into five approximately equal parts from low to high. The quintiles are constructed on a monthly basis. This means that the divisions are conducted for every month. Thus, the position within a quintile is fixed within a month, but it can differ between months. The quintile analysis is conducted with a minimum of five trades larger than the prevailing interest rate. The overall, buy and sell herding measures are presented in columns HMit, BHMit and SHMit, respectively.

\begin{tabular}{|c|c|c|c|c|c|c|}
\hline \multicolumn{7}{|c|}{ Sovereign ratings } \\
\hline Quintile & HMit & Observations & BHMit & Observations & SHMit & Observations \\
\hline 1 & 0.12 & 14460 & 0.14 & 11490 & 0.04 & 2970 \\
\hline 2 & 0.10 & 6036 & 0.11 & 4619 & 0.07 & 1417 \\
\hline 3 & 0.11 & 8225 & 0.10 & 4352 & 0.12 & 3873 \\
\hline 4 & 0.16 & 5271 & 0.08 & 1873 & 0.21 & 3398 \\
\hline 5 & 0.23 & 3064 & 0.10 & 537 & 0.26 & 2527 \\
\hline
\end{tabular}

\section{GDP growth}

\begin{tabular}{lllllll}
\hline Quintile & HMit & Observations & BHMit & Observations & SHMit & Observations \\
\hline 1 & 0.15 & 7934 & 0.14 & 4939 & 0.15 & 2995 \\
2 & 0.12 & 8093 & 0.12 & 5430 & 0.13 & 2663 \\
3 & 0.11 & 8590 & 0.12 & 6272 & 0.10 & 2318 \\
4 & 0.12 & 7799 & 0.12 & 4564 & 0.12 & 3235 \\
5 & 0.18 & 4788 & 0.10 & 1682 & 0.22 & 3106 \\
\hline
\end{tabular}

Size of the sovereign debt market

\begin{tabular}{lllllll}
\hline Quintile & HMit & Observations & BHMit & Observations & SHMit & Observations \\
\hline 1 & 0.17 & 4610 & 0.16 & 2781 & 0.19 & 1829 \\
2 & 0.15 & 5991 & 0.16 & 4158 & 0.12 & 1833 \\
3 & 0.12 & 6944 & 0.13 & 5629 & 0.06 & 1315 \\
4 & 0.10 & 5765 & 0.10 & 3617 & 0.10 & 2148 \\
5 & 0.07 & 5994 & 0.08 & 4166 & 0.04 & 1828 \\
\hline
\end{tabular}

Number of countries in the pension fund's sovereign bond portfolio

\begin{tabular}{lllllll}
\hline Quintile & HMit & Observations & BHMit & Observations & SHMit & Observations \\
\hline 1 & 0.11 & 10080 & 0.13 & 7836 & 0.06 & 2244 \\
2 & 0.13 & 7979 & 0.13 & 5154 & 0.12 & 2825 \\
3 & 0.14 & 7641 & 0.11 & 4022 & 0.17 & 3619 \\
4 & 0.15 & 6638 & 0.11 & 3355 & 0.18 & 3283 \\
5 & 0.14 & 4866 & 0.11 & 2520 & 0.18 & 2346 \\
\hline
\end{tabular}

\section{Interest rate}

\begin{tabular}{lllllll}
\hline Quintile & HMit & Observations & BHMit & Observations & SHMit & Observations \\
\hline 1 & 0.12 & 9824 & 0.14 & 8051 & 0.05 & 1773 \\
2 & 0.12 & 6117 & 0.14 & 4948 & 0.04 & 1169 \\
3 & 0.11 & 6616 & 0.13 & 4651 & 0.06 & 1965 \\
4 & 0.08 & 5517 & 0.08 & 2957 & 0.08 & 2560 \\
5 & 0.08 & 5084 & 0.07 & 2280 & 0.09 & 2804 \\
\hline
\end{tabular}


CDS spread

\begin{tabular}{lllllll}
\hline Quintile & HMit & Observations & BHMit & Observations & SHMit & Observations \\
\hline 1 & 0.12 & 10084 & 0.14 & 8091 & 0.05 & 1993 \\
2 & 0.12 & 8181 & 0.13 & 6459 & 0.06 & 1722 \\
3 & 0.11 & 6784 & 0.09 & 3656 & 0.13 & 3128 \\
4 & 0.13 & 6082 & 0.09 & 2713 & 0.17 & 3369 \\
5 & 0.19 & 3906 & 0.08 & 940 & 0.23 & 2966 \\
\hline
\end{tabular}

Current account

\begin{tabular}{lllllll}
\hline Quintile & HMit & Observations & BHMit & Observations & SHMit & Observations \\
\hline 1 & 0.18 & 4816 & 0.10 & 1814 & 0.23 & 3002 \\
2 & 0.11 & 7867 & 0.09 & 4027 & 0.14 & 3840 \\
3 & 0.12 & 7990 & 0.12 & 5067 & 0.13 & 2923 \\
4 & 0.14 & 8001 & 0.14 & 5456 & 0.13 & 2545 \\
5 & 0.12 & 8530 & 0.13 & 6523 & 0.09 & 2007 \\
\hline
\end{tabular}

Average monthly sovereign holdings by pension fund

\begin{tabular}{lllllll}
\hline Quintile & HMit & Observations & BHMit & Observations & SHMit & Observations \\
\hline 1 & 0.12 & 8993 & 0.12 & 6180 & 0.11 & 2813 \\
2 & 0.13 & 7630 & 0.12 & 4670 & 0.14 & 2960 \\
3 & 0.13 & 7291 & 0.12 & 4407 & 0.15 & 2884 \\
4 & 0.14 & 7156 & 0.13 & 4321 & 0.16 & 2835 \\
5 & 0.14 & 6134 & 0.11 & 3309 & 0.17 & 2825 \\
\hline
\end{tabular}

Sovereign holdings in a country as a percentage of the pension fund's total sovereign holdings

\begin{tabular}{lllllll}
\hline Quintile & HMit & Observations & BHMit & Observations & SHMit & Observations \\
\hline 1 & 0.17 & 4202 & 0.11 & 1657 & 0.21 & 2545 \\
2 & 0.16 & 5944 & 0.13 & 2810 & 0.19 & 3134 \\
3 & 0.14 & 7640 & 0.13 & 4251 & 0.16 & 3389 \\
4 & 0.12 & 9038 & 0.13 & 6023 & 0.11 & 3015 \\
5 & 0.10 & 10380 & 0.11 & 8146 & 0.04 & 2234 \\
\hline
\end{tabular}

\section{Corruption}

\begin{tabular}{lllllll}
\hline Quintile & HMit & Observations & BHMit & Observations & SHMit & Observations \\
\hline 1 & 0.16 & 4925 & 0.07 & 1520 & 0.20 & 3405 \\
2 & 0.16 & 6001 & 0.09 & 2378 & 0.20 & 3623 \\
3 & 0.12 & 7357 & 0.11 & 4049 & 0.12 & 3308 \\
4 & 0.10 & 9437 & 0.11 & 6866 & 0.08 & 2571 \\
5 & 0.14 & 9484 & 0.16 & 8074 & 0.06 & 1410 \\
\hline
\end{tabular}


Political stability

\begin{tabular}{lllllll}
\hline Quintile & HMit & Observations & BHMit & Observations & SHMit & Observations \\
\hline 1 & 0.14 & 6316 & 0.08 & 2517 & 0.18 & 3799 \\
2 & 0.17 & 5316 & 0.08 & 1883 & 0.21 & 3433 \\
3 & 0.10 & 7864 & 0.10 & 4749 & 0.10 & 3115 \\
4 & 0.11 & 8715 & 0.12 & 6164 & 0.08 & 2551 \\
5 & 0.16 & 8993 & 0.17 & 7574 & 0.10 & 1419 \\
\hline
\end{tabular}

\section{Regulatory quality}

\begin{tabular}{lllllll}
\hline Quintile & HMit & Observations & BHMit & Observations & SHMit & Observations \\
\hline 1 & 0.19 & 4426 & 0.09 & 1211 & 0.22 & 3215 \\
2 & 0.18 & 5627 & 0.08 & 1922 & 0.23 & 3705 \\
3 & 0.09 & 8118 & 0.10 & 4672 & 0.09 & 3446 \\
4 & 0.10 & 10074 & 0.12 & 7812 & 0.06 & 2262 \\
5 & 0.14 & 8959 & 0.16 & 7270 & 0.06 & 1689 \\
\hline
\end{tabular}

Absolute distance to the strategic asset allocation

\begin{tabular}{lllllll}
\hline Quintile & HMit & Observations & BHMit & Observations & SHMit & Observations \\
\hline 1 & 0.14 & 7473 & 0.12 & 4232 & 0.16 & 3241 \\
2 & 0.13 & 6744 & 0.12 & 3957 & 0.15 & 2787 \\
3 & 0.13 & 6353 & 0.12 & 3837 & 0.15 & 2516 \\
4 & 0.13 & 7449 & 0.12 & 4688 & 0.13 & 2761 \\
5 & 0.13 & 6937 & 0.13 & 4570 & 0.13 & 2367 \\
\hline
\end{tabular}

Pension fund size

\begin{tabular}{lllllll}
\hline Quintile & HMit & Observations & BHMit & Observations & SHMit & Observations \\
\hline 1 & 0.12 & 7936 & 0.12 & 5298 & 0.12 & 2638 \\
2 & 0.13 & 7252 & 0.13 & 4689 & 0.13 & 2563 \\
3 & 0.14 & 7559 & 0.13 & 4496 & 0.15 & 3063 \\
4 & 0.13 & 7060 & 0.11 & 4087 & 0.16 & 2973 \\
5 & 0.14 & 5149 & 0.11 & 2714 & 0.17 & 2435 \\
\hline
\end{tabular}

\begin{tabular}{lllllll} 
Yield & \multicolumn{7}{l}{ Obintile } & HMit & Observations & BHMit & Observations & SHMit & Observations \\
\hline 1 & 0.12 & 9823 & 0.14 & 7834 & 0.05 & 1989 \\
2 & 0.12 & 8043 & 0.14 & 6342 & 0.05 & 1701 \\
3 & 0.11 & 6719 & 0.11 & 3837 & 0.12 & 2882 \\
4 & 0.12 & 5486 & 0.09 & 2340 & 0.14 & 3146 \\
5 & 0.20 & 3881 & 0.07 & 926 & 0.23 & 2955 \\
\hline
\end{tabular}


Table 10. Quintile analysis using the prevailing interest rate augmented with WEO country-groups average interest rates

We form quintiles for the indicators. These are divided into five approximately equal parts from low to high. The quintiles are constructed on a monthly basis. This means that the divisions are conducted for every month. Thus, the position within a quintile is fixed within a month, but it can differ between months. The quintile analysis is conducted with a minimum of five trades larger than the prevailing interest rate augmented with WEO country groups' average interest rates. The overall, buy and sell herding measures are presented in columns HMit, BHMit and SHMit, respectively.

\begin{tabular}{lllllll}
\hline \multicolumn{2}{l}{ Sovereign ratings } & \multicolumn{7}{l}{} \\
\hline Quintile & HMit & Observations & BHMit & Observations & SHMit & Observations \\
\hline 1 & 0.09 & 14460 & 0.11 & 10220 & 0.06 & 4240 \\
2 & 0.08 & 6105 & 0.08 & 3881 & 0.07 & 2224 \\
3 & 0.09 & 9101 & 0.08 & 4072 & 0.11 & 5029 \\
4 & 0.09 & 7868 & 0.06 & 3048 & 0.12 & 4820 \\
5 & 0.12 & 6230 & 0.07 & 2603 & 0.15 & 3627 \\
\hline
\end{tabular}

Size of the sovereign debt market

\begin{tabular}{lllllll}
\hline Quintile & HMit & Observations & BHMit & Observations & SHMit & Observations \\
\hline 1 & 0.12 & 5654 & 0.11 & 3123 & 0.14 & 2531 \\
2 & 0.12 & 6390 & 0.13 & 3975 & 0.10 & 2415 \\
3 & 0.09 & 7081 & 0.10 & 5029 & 0.06 & 2052 \\
4 & 0.07 & 6162 & 0.07 & 3201 & 0.08 & 2961 \\
5 & 0.05 & 6068 & 0.04 & 3426 & 0.06 & 2642 \\
\hline
\end{tabular}

Number of countries in the pension fund's sovereign bond portfolio

\begin{tabular}{lllllll}
\hline Quintile & HMit & Observations & BHMit & Observations & SHMit & Observations \\
\hline 1 & 0.09 & 10060 & 0.10 & 6809 & 0.07 & 3251 \\
2 & 0.10 & 8916 & 0.09 & 4967 & 0.10 & 3949 \\
3 & 0.10 & 9514 & 0.08 & 4615 & 0.11 & 4899 \\
4 & 0.10 & 8631 & 0.08 & 4117 & 0.12 & 4514 \\
5 & 0.10 & 6922 & 0.08 & 3387 & 0.12 & 3535 \\
\hline
\end{tabular}

\begin{tabular}{lllllll}
\multicolumn{2}{l}{ Interest rate } \\
\hline Quintile & HMit & Observations & BHMit & Observations & SHMit & Observations \\
\hline 1 & 0.09 & 9824 & 0.10 & 6992 & 0.05 & 2832 \\
2 & 0.09 & 6117 & 0.11 & 4371 & 0.05 & 1746 \\
3 & 0.10 & 6616 & 0.10 & 4109 & 0.09 & 2507 \\
4 & 0.09 & 5517 & 0.06 & 2347 & 0.10 & 3170 \\
5 & 0.09 & 5084 & 0.04 & 1817 & 0.12 & 3267 \\
\hline
\end{tabular}

CDS spread

\begin{tabular}{lllllll}
\hline Quintile & HMit & Observations & BHMit & Observations & SHMit & Observations \\
\hline 1 & 0.09 & 10143 & 0.11 & 7017 & 0.06 & 3126 \\
2 & 0.09 & 8327 & 0.10 & 5838 & 0.08 & 2489 \\
3 & 0.08 & 7707 & 0.06 & 3334 & 0.10 & 4373 \\
4 & 0.08 & 7839 & 0.06 & 3314 & 0.10 & 4525 \\
5 & 0.11 & 6573 & 0.06 & 2502 & 0.15 & 4071 \\
\hline
\end{tabular}


Average monthly sovereign holdings per pension fund

\begin{tabular}{lllllll}
\hline Quintile & HMit & Observations & BHMit & Observations & SHMit & Observations \\
\hline 1 & 0.09 & 9518 & 0.09 & 5654 & 0.09 & 3864 \\
2 & 0.09 & 8967 & 0.08 & 4823 & 0.10 & 4144 \\
3 & 0.10 & 8679 & 0.09 & 4635 & 0.11 & 4044 \\
4 & 0.10 & 8886 & 0.09 & 4787 & 0.11 & 4099 \\
5 & 0.10 & 7993 & 0.08 & 3996 & 0.11 & 3997 \\
\hline
\end{tabular}

Sovereign holdings in a country as a percentage of the pension fund's total sovereign holdings

\begin{tabular}{lllllll}
\hline Quintile & HMit & Observations & BHMit & Observations & SHMit & Observations \\
\hline 1 & 0.12 & 6886 & 0.08 & 3155 & 0.14 & 3731 \\
2 & 0.11 & 8177 & 0.08 & 3767 & 0.12 & 4410 \\
3 & 0.10 & 8966 & 0.09 & 4408 & 0.11 & 4558 \\
4 & 0.09 & 9619 & 0.10 & 5587 & 0.09 & 4032 \\
5 & 0.07 & 10395 & 0.08 & 6978 & 0.06 & 3417 \\
\hline
\end{tabular}

Political stability

\begin{tabular}{lllllll}
\hline Quintile & HMit & Observations & BHMit & Observations & SHMit & Observations \\
\hline 1 & 0.09 & 8724 & 0.05 & 3539 & 0.12 & 5185 \\
2 & 0.10 & 8016 & 0.05 & 3142 & 0.12 & 4874 \\
3 & 0.08 & 8983 & 0.07 & 4667 & 0.09 & 4316 \\
4 & 0.09 & 9120 & 0.09 & 5489 & 0.08 & 3631 \\
5 & 0.12 & 9200 & 0.13 & 7058 & 0.09 & 2142 \\
\hline
\end{tabular}

Absolute distance to the strategic asset allocation

\begin{tabular}{|c|c|c|c|c|c|c|}
\hline Quintile & HMit & Observations & BHMit & Observations & SHMit & Observations \\
\hline 1 & 0.10 & 9035 & 0.08 & 4657 & 0.11 & 4378 \\
\hline 2 & 0.10 & 8379 & 0.09 & 4428 & 0.11 & 3951 \\
\hline 3 & 0.10 & 7802 & 0.09 & 4167 & 0.11 & 3635 \\
\hline 4 & 0.09 & 8482 & 0.09 & 4689 & 0.10 & 3793 \\
\hline 5 & 0.10 & 7668 & 0.09 & 4431 & 0.10 & 3237 \\
\hline \multicolumn{7}{|l|}{ Yield } \\
\hline Quintile & HMit & Observations & BHMit & Observations & SHMit & Observations \\
\hline 1 & 0.09 & 9995 & 0.10 & 6923 & 0.06 & 3072 \\
\hline 2 & 0.09 & 8016 & 0.10 & 5667 & 0.07 & 2349 \\
\hline 3 & 0.10 & 7330 & 0.08 & 3507 & 0.11 & 3823 \\
\hline 4 & 0.09 & 7011 & 0.06 & 3019 & 0.12 & 3992 \\
\hline 5 & 0.10 & 6546 & 0.06 & 2358 & 0.12 & 4188 \\
\hline
\end{tabular}


Table 11. S\&P credit ratings and numerical linear transformation

\begin{tabular}{|c|c|c|}
\hline Grade & S\&P Long Term & $\begin{array}{l}\text { Numerical linear } \\
\text { transformation }\end{array}$ \\
\hline Prime & AAA & 1 \\
\hline \multirow[t]{3}{*}{ High grade } & $\mathrm{AA}+$ & 2 \\
\hline & $\mathrm{AA}$ & 3 \\
\hline & AA- & 4 \\
\hline \multirow[t]{3}{*}{ Upper medium grade } & $\mathrm{A}+$ & 5 \\
\hline & A & 6 \\
\hline & A- & 7 \\
\hline \multirow[t]{3}{*}{ Lower medium grade } & $\mathrm{BBB}+$ & 8 \\
\hline & BBB & 9 \\
\hline & BBB- & 10 \\
\hline Noninvestment & $\mathrm{BB}+$ & 11 \\
\hline \multirow[t]{2}{*}{ grade speculative } & $\mathrm{BB}$ & 12 \\
\hline & BB- & 13 \\
\hline \multirow[t]{3}{*}{ Highly speculative } & $\mathrm{B}+$ & 14 \\
\hline & B & 15 \\
\hline & B- & 16 \\
\hline Substantial risks & $\mathrm{CCC}+$ & 17 \\
\hline Extremely speculative & $\mathrm{CCC}$ & 18 \\
\hline In default with little & CCC- & 19 \\
\hline \multirow[t]{2}{*}{ prospect for recovery } & $\mathrm{CC}$ & 20 \\
\hline & $\mathrm{C}$ & 21 \\
\hline In default & $\mathrm{D}$ & 22 \\
\hline
\end{tabular}




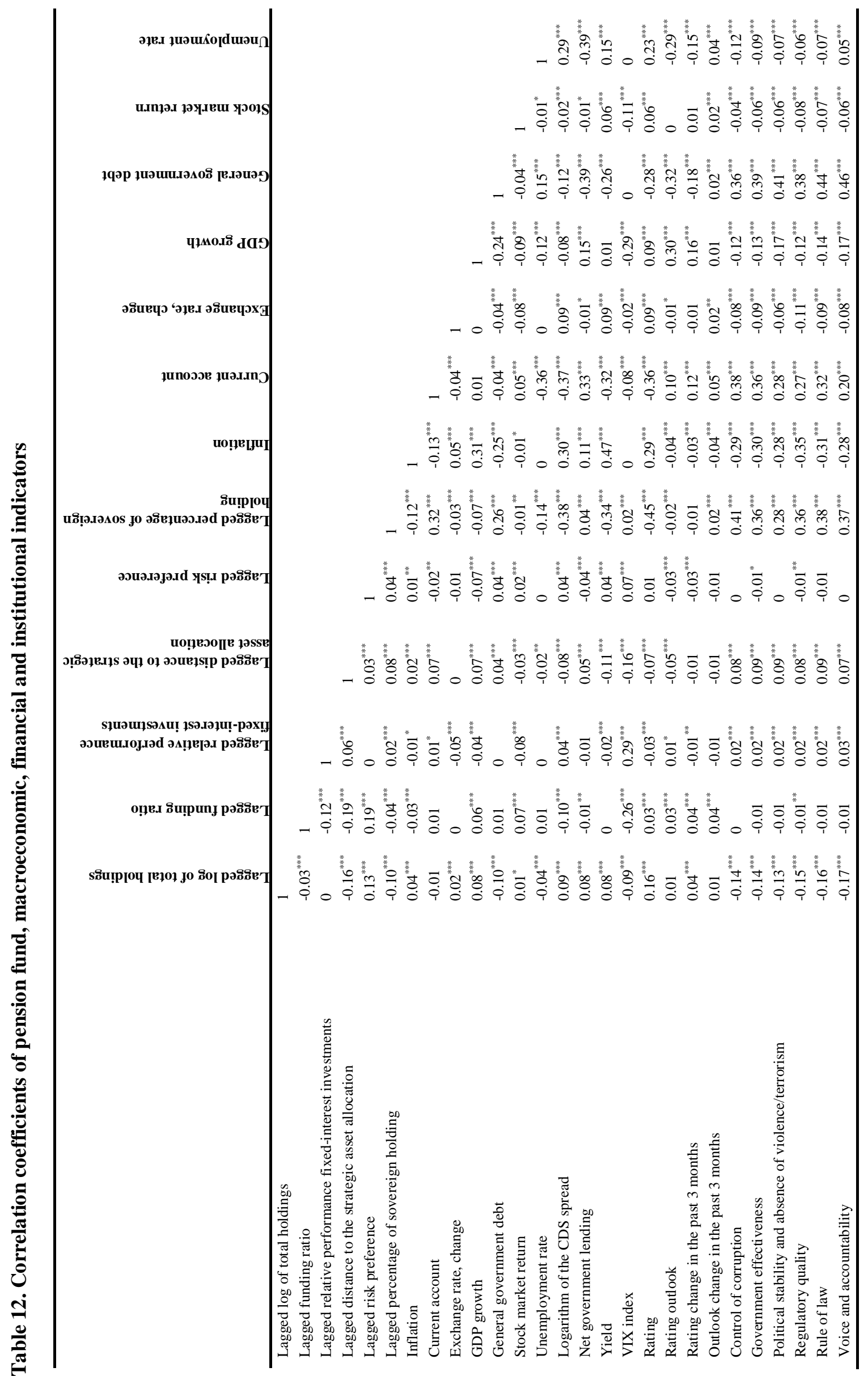




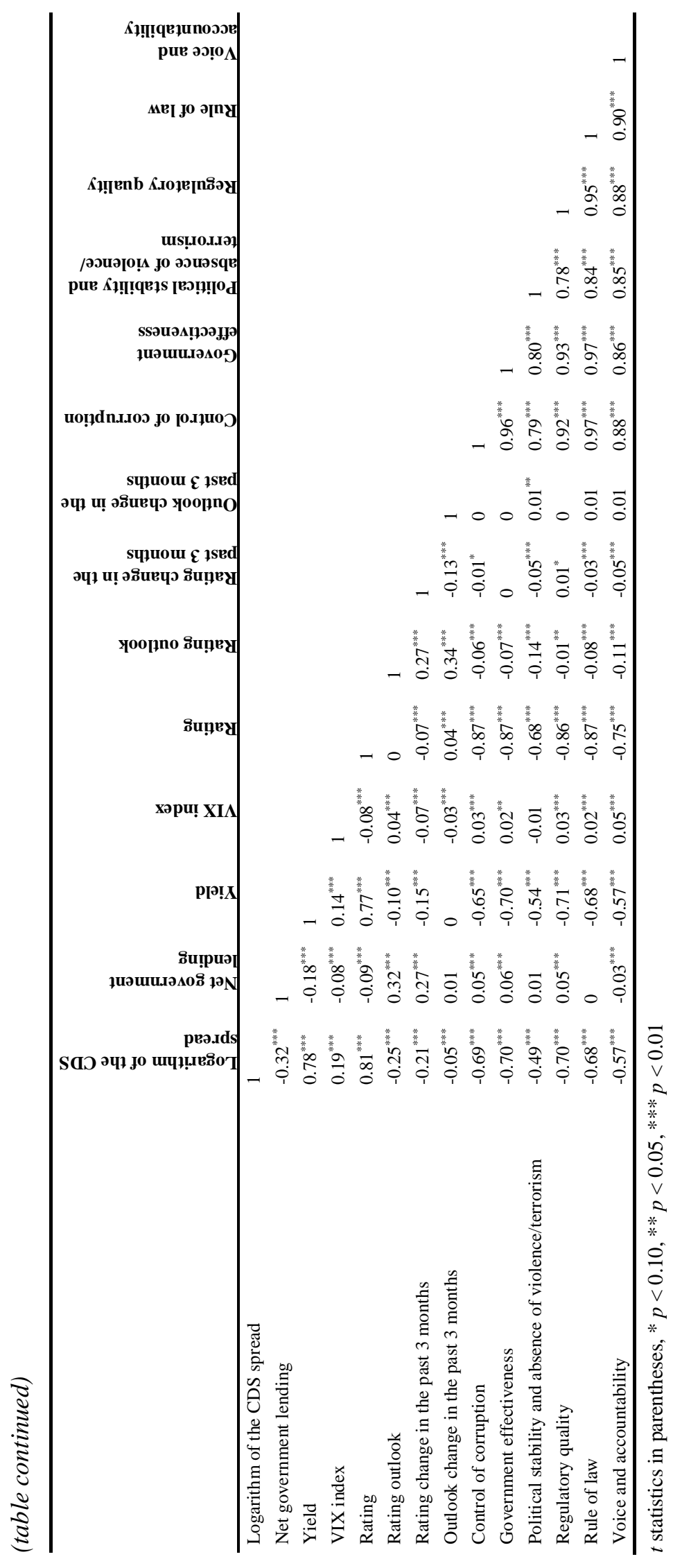




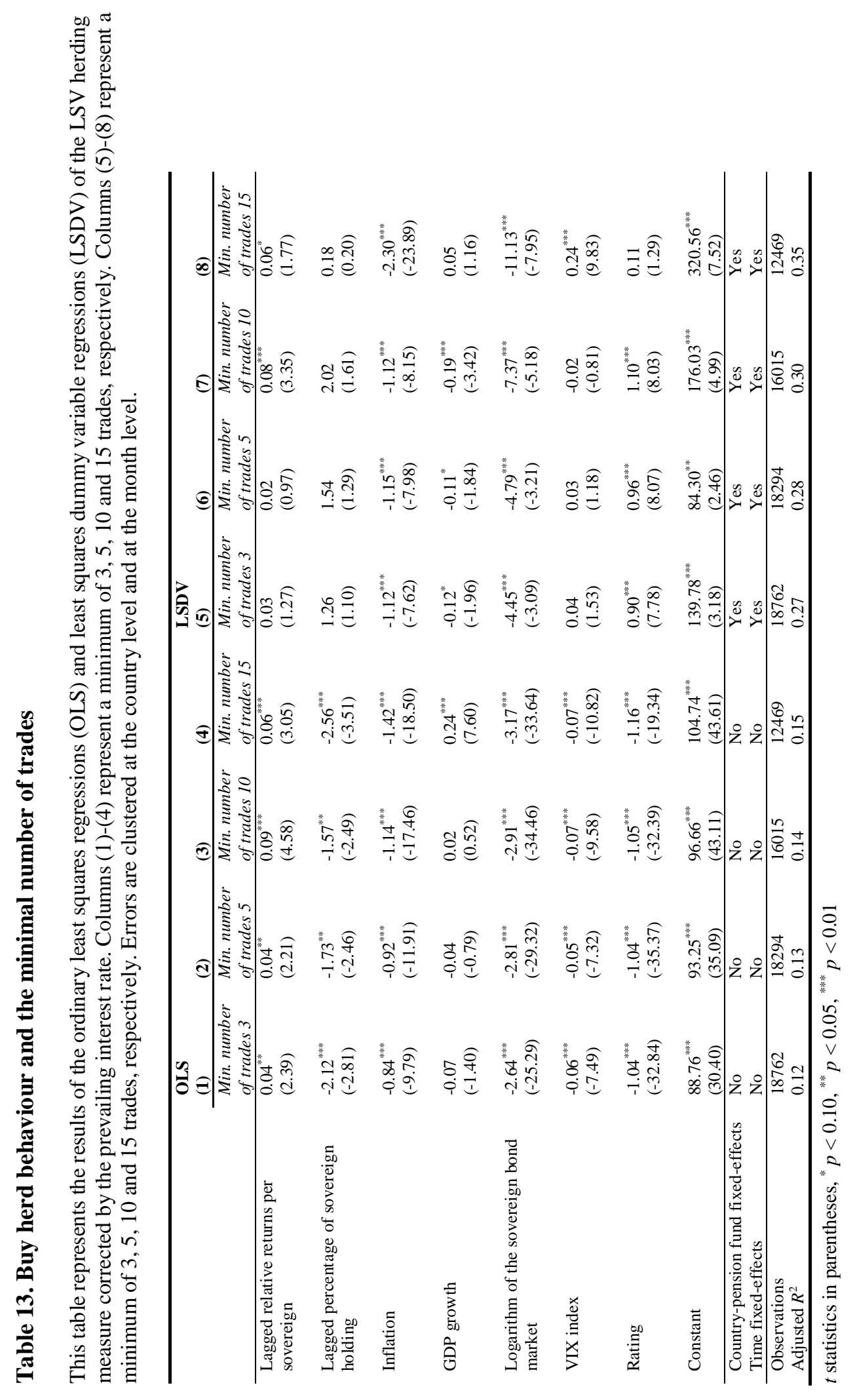




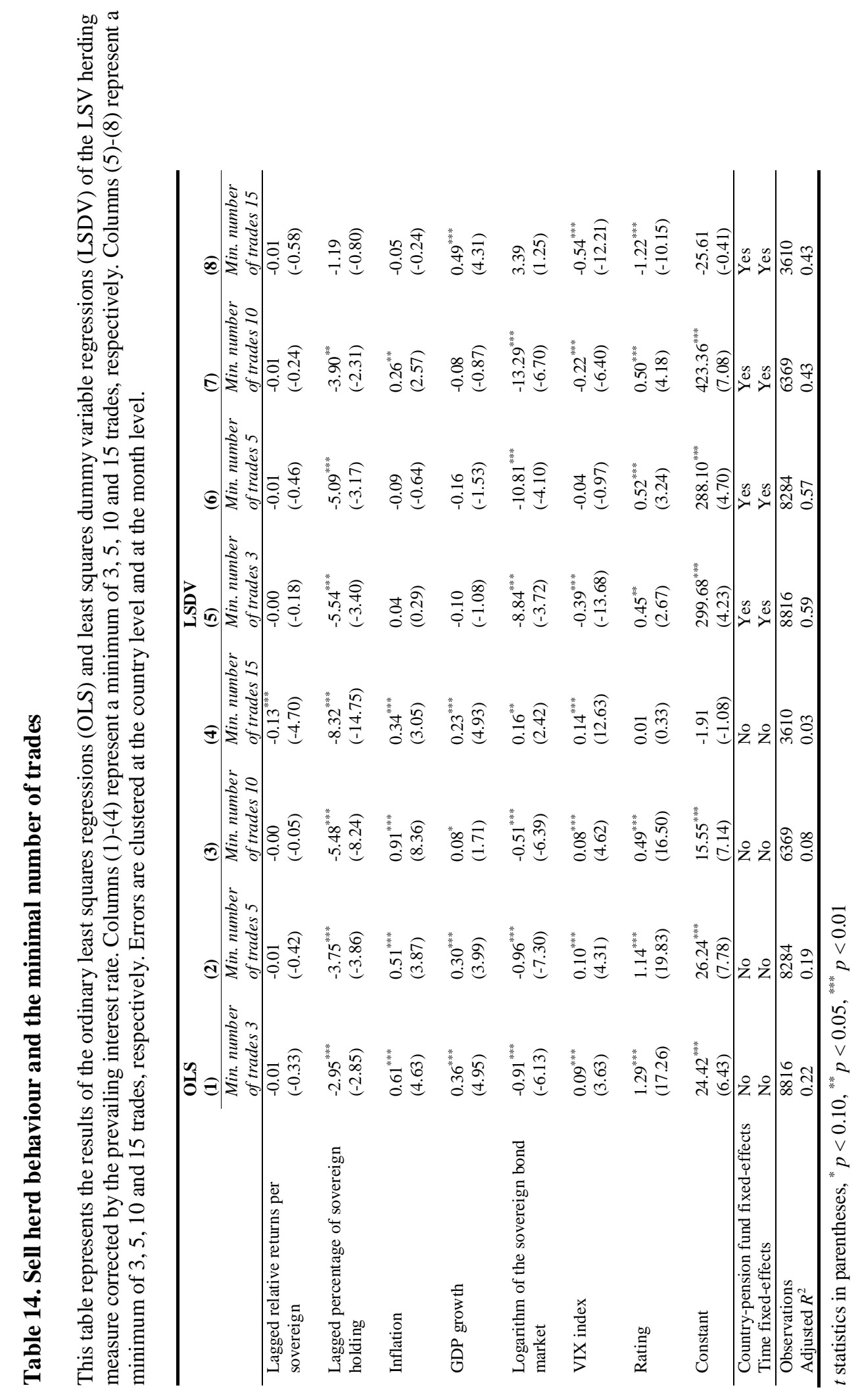




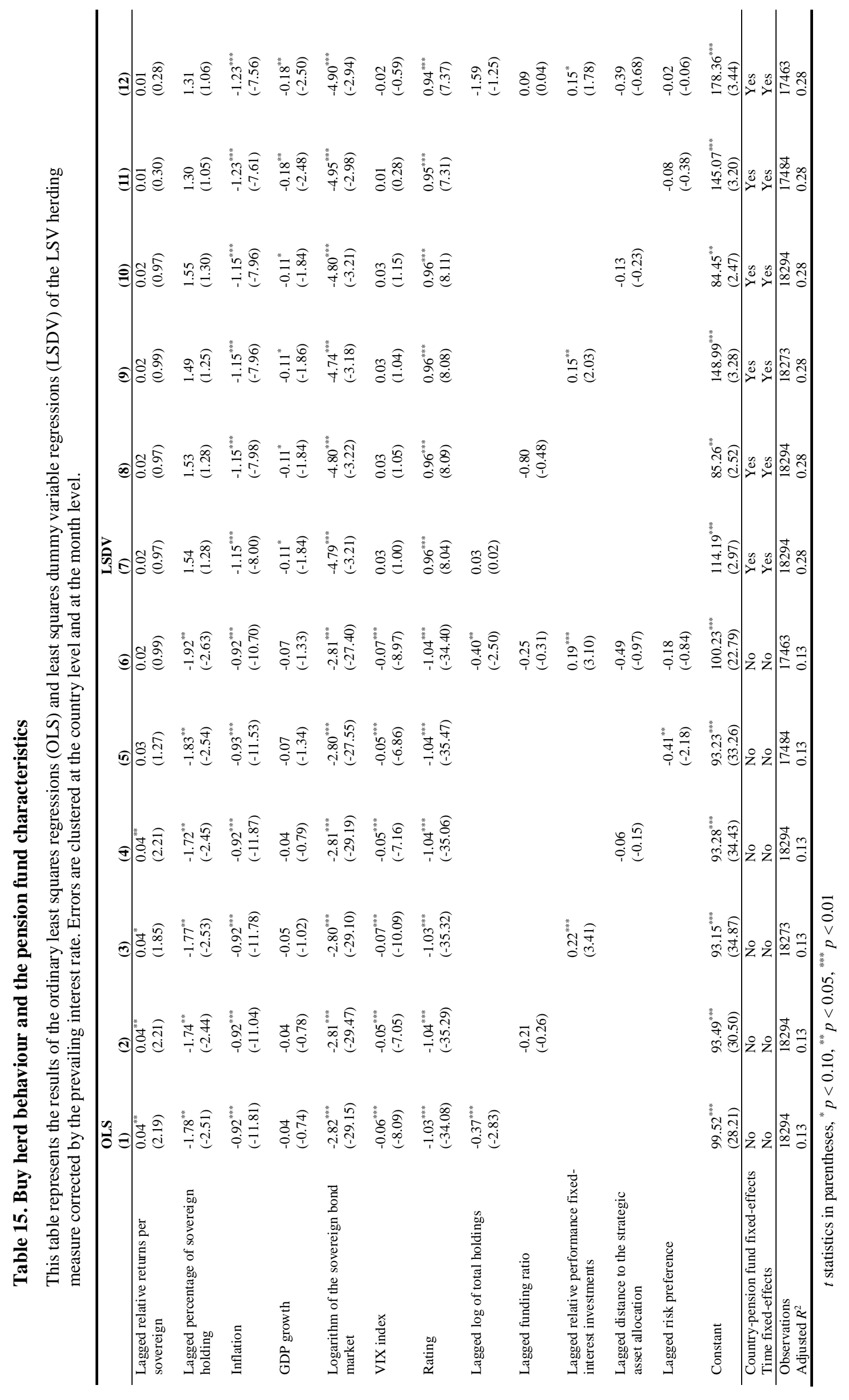




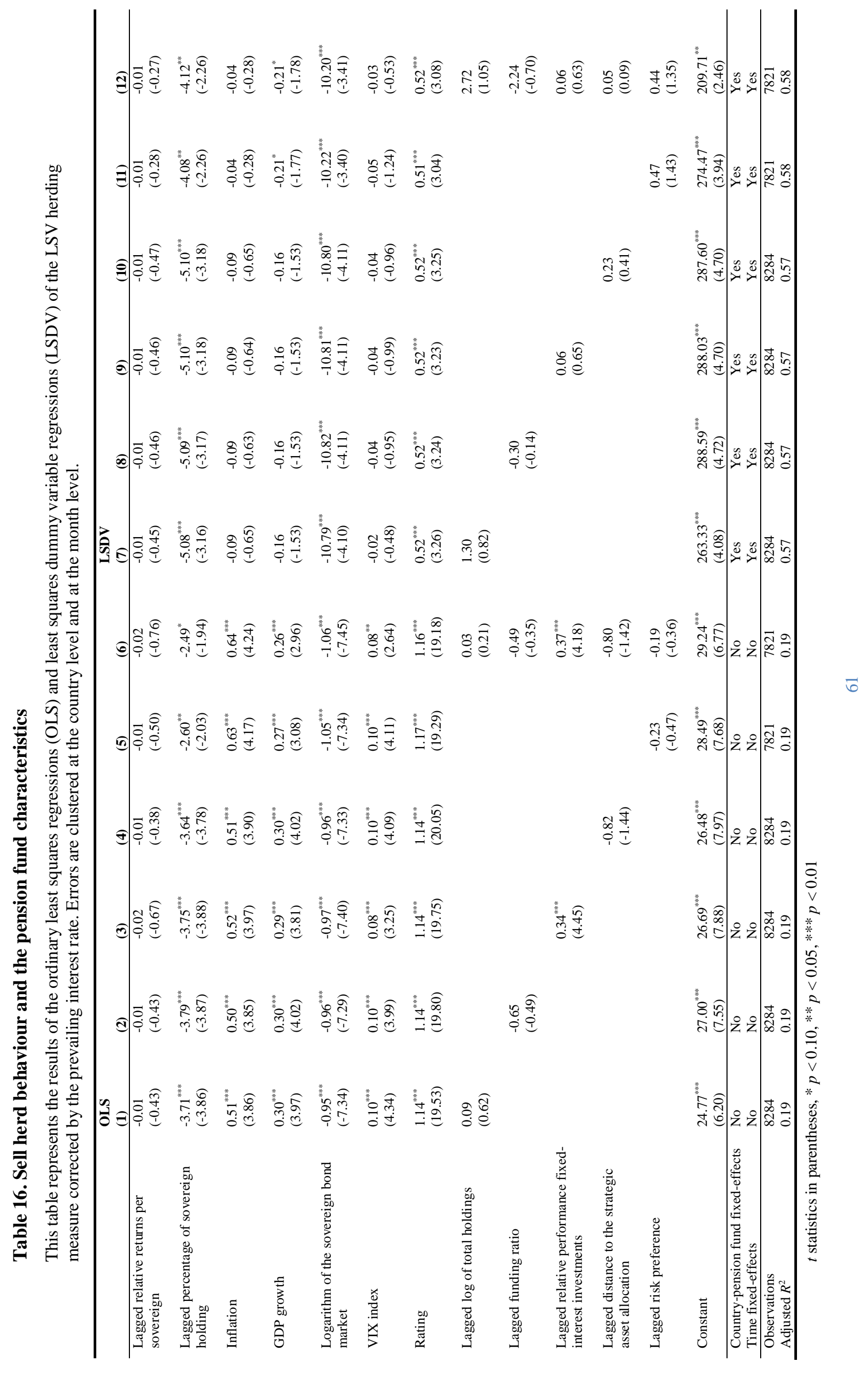




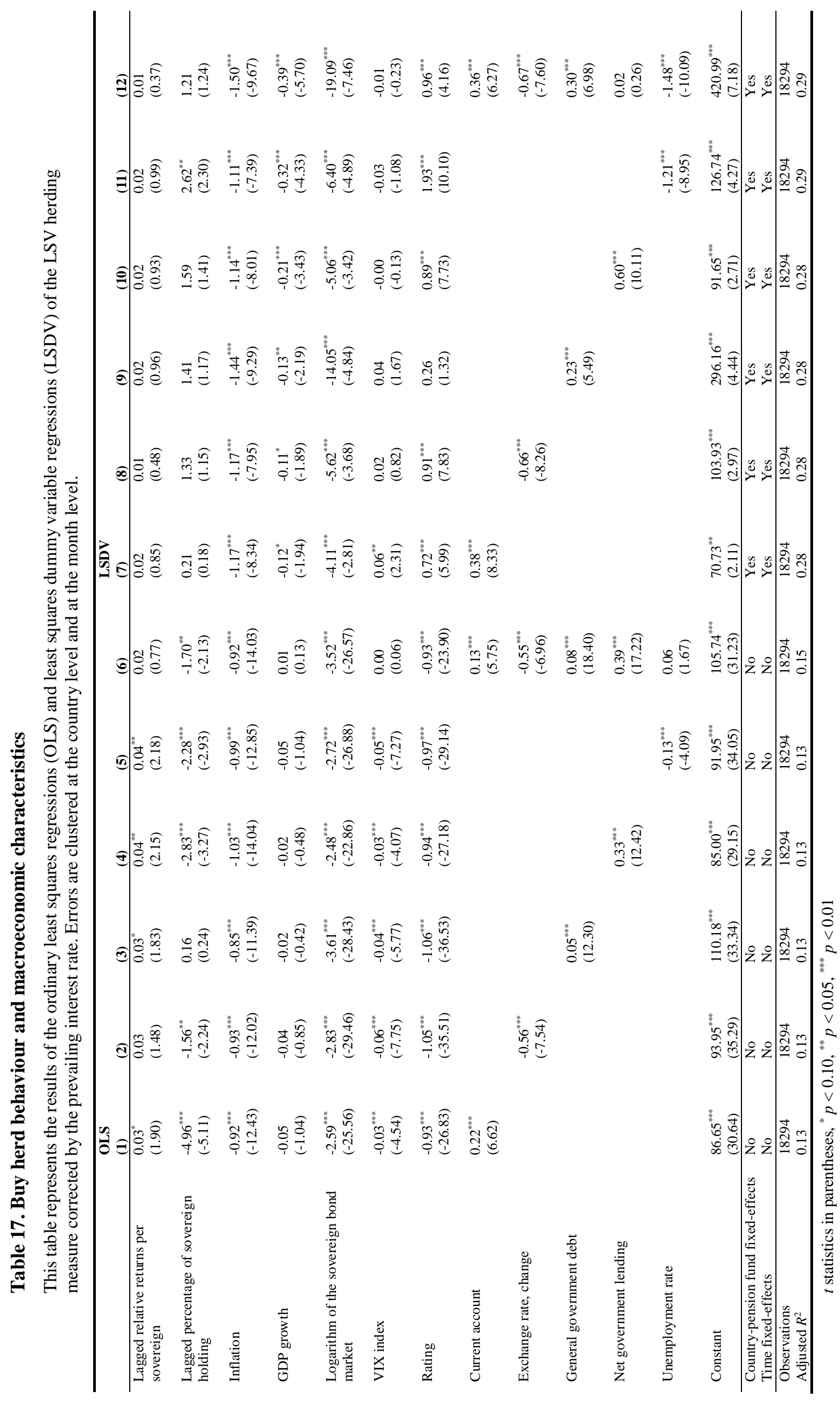




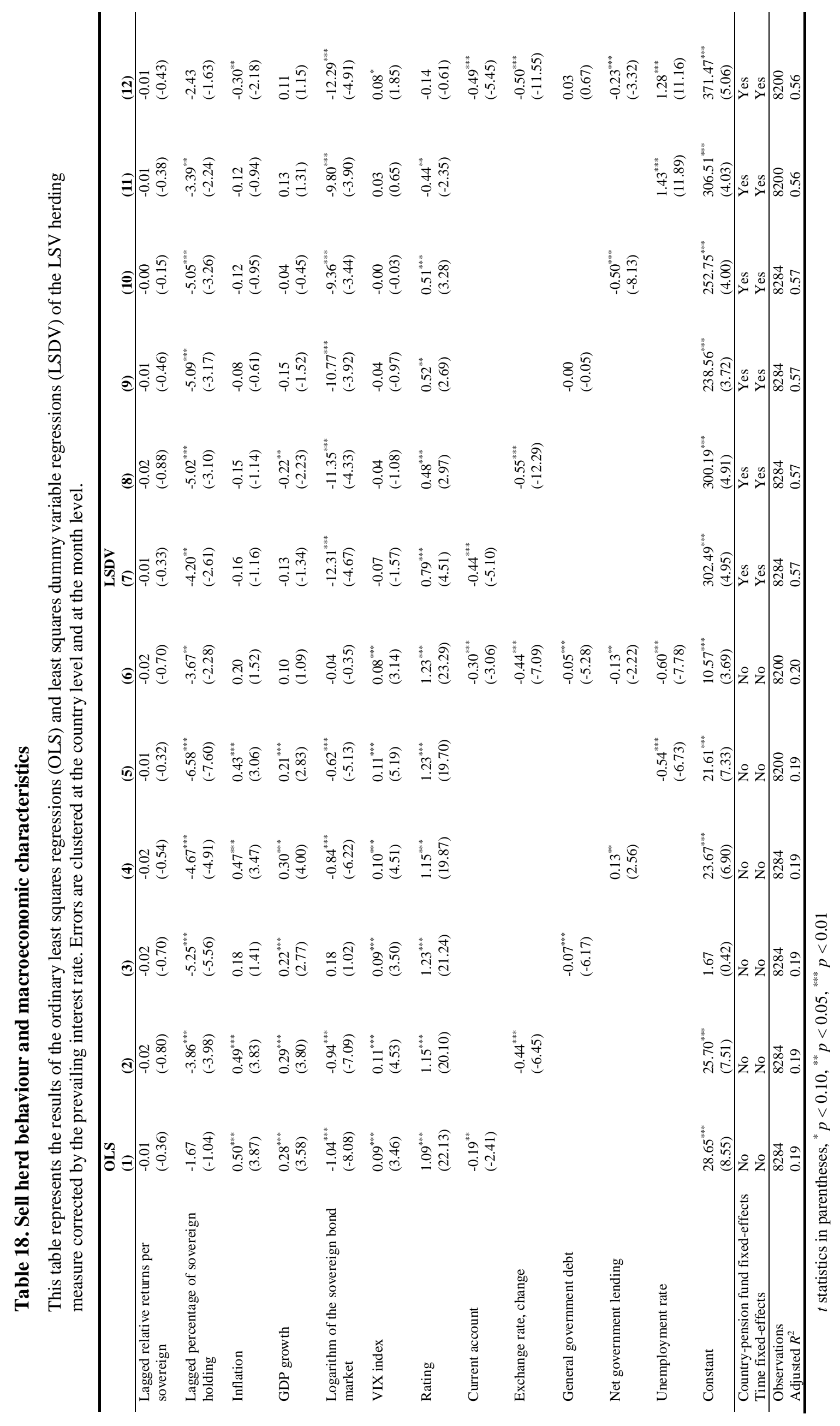




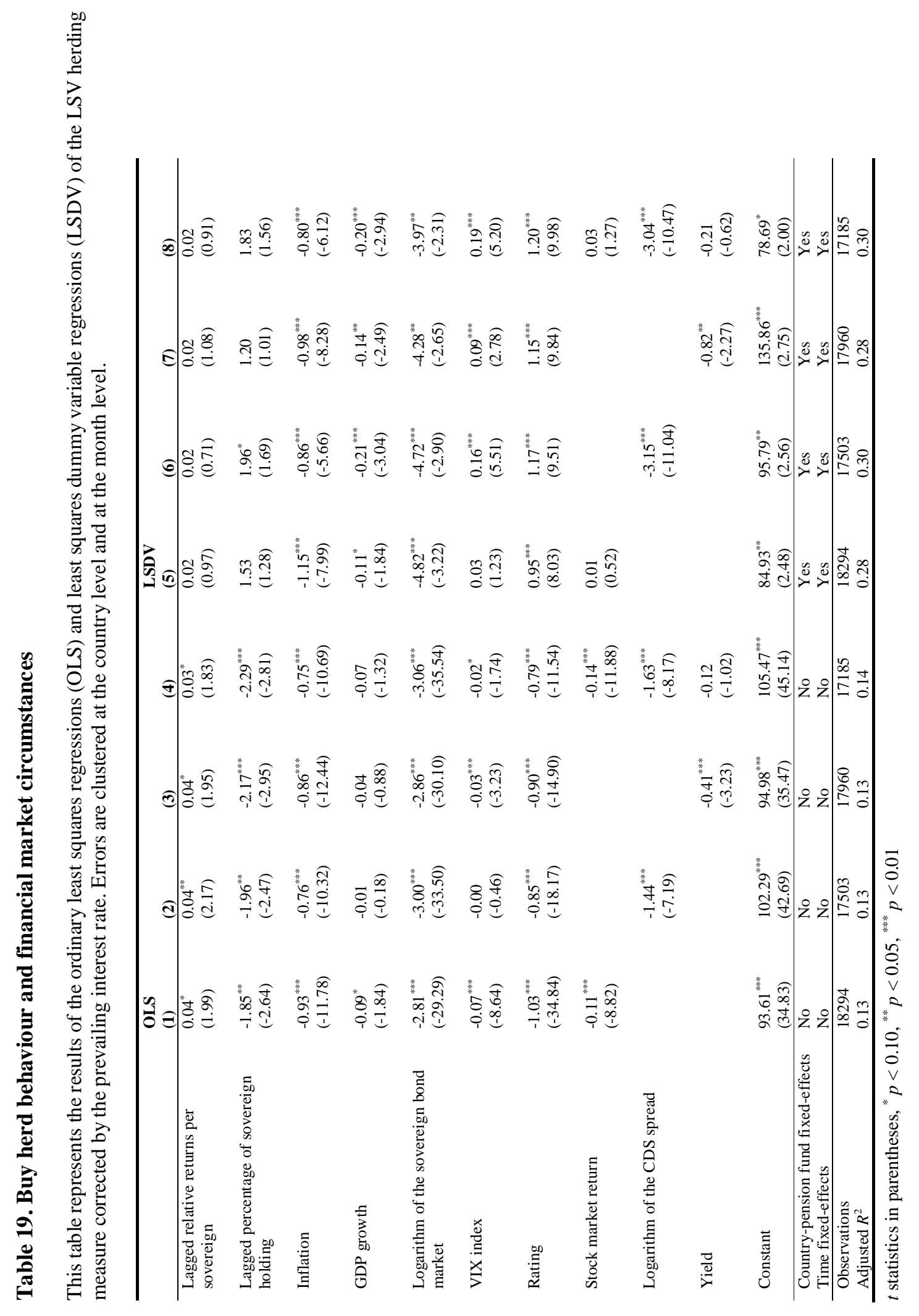




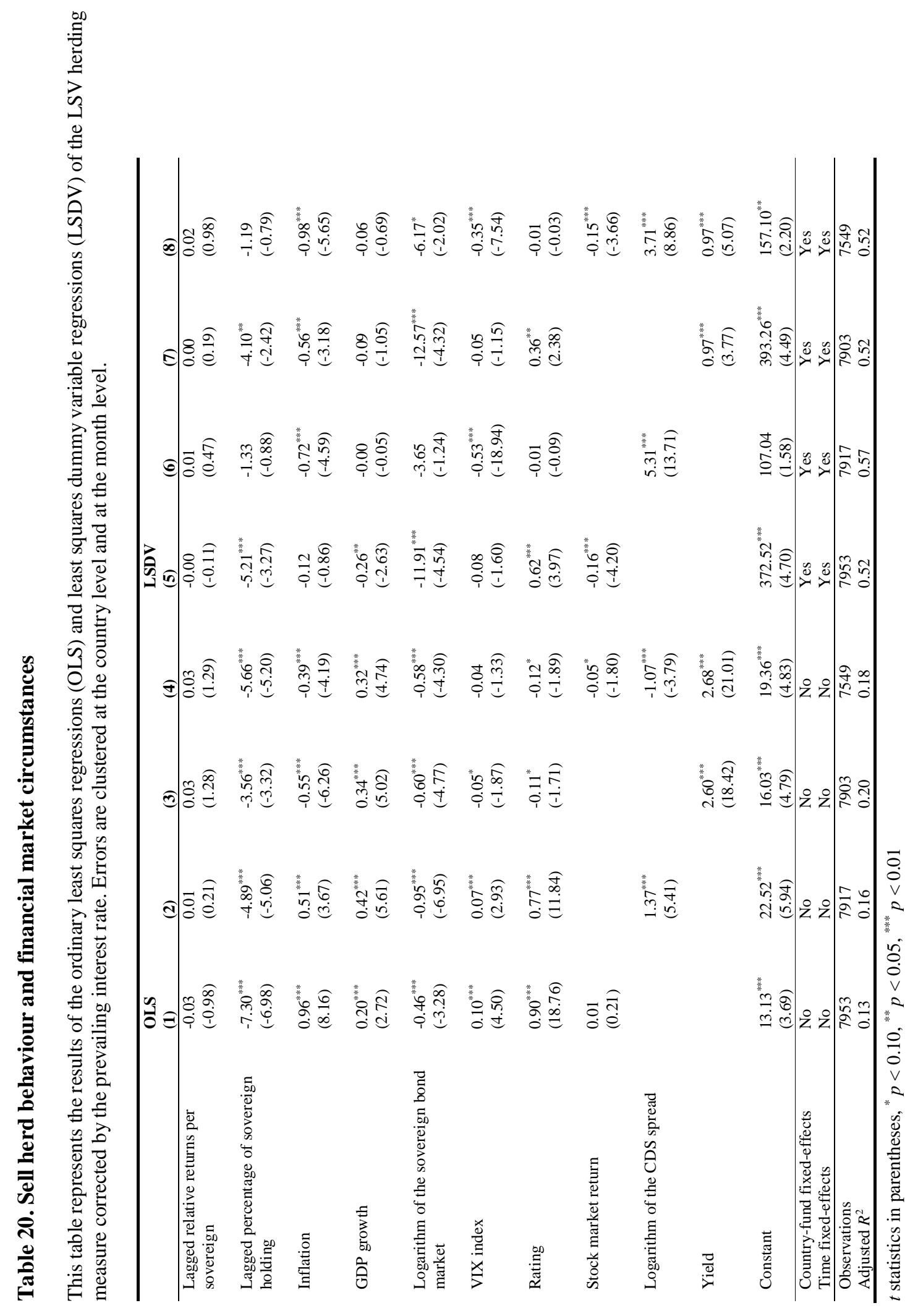




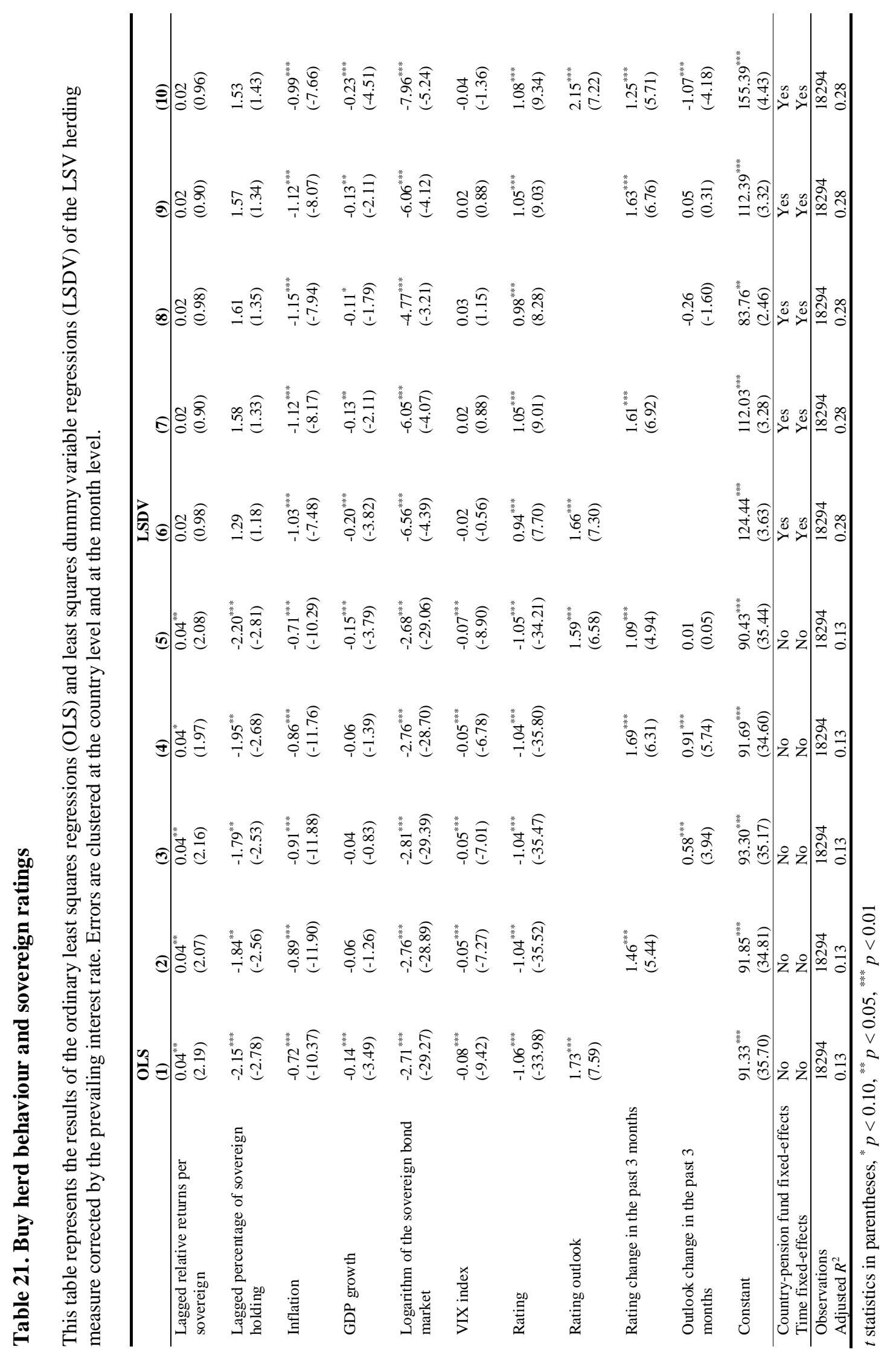




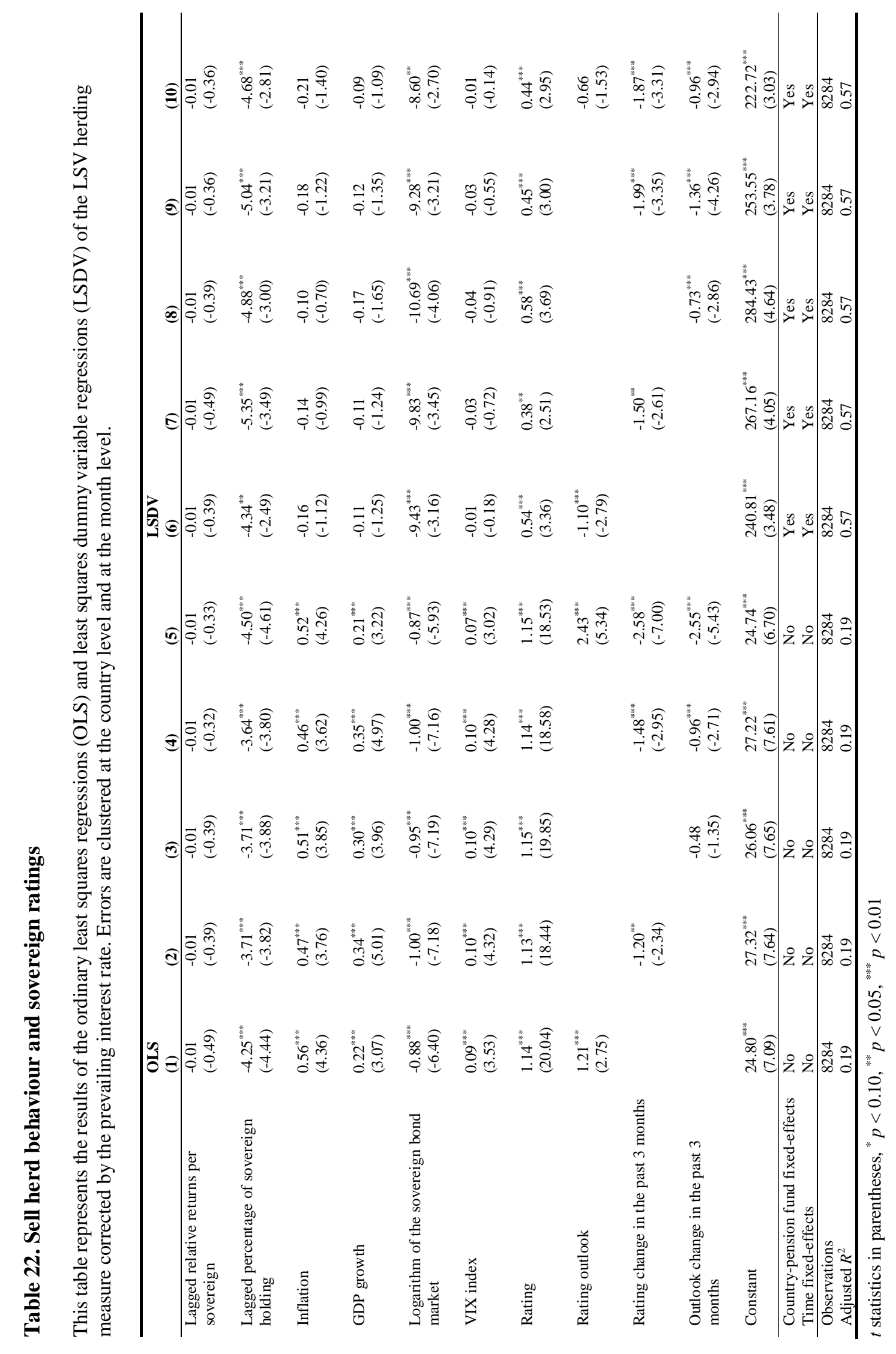




\section{Table 23. Buy herd behaviour and institutional factors}

This table represents the results of the ordinary least squares regressions (OLS) and least squares dummy variable regressions (LSDV) of the LSV herding measure corrected by the prevailing interest rate. Errors are clustered at the country level and at the month level.

\begin{tabular}{|c|c|c|c|c|c|c|c|}
\hline & $\begin{array}{l}\text { OLS } \\
\text { (1) }\end{array}$ & (2) & (3) & (4) & (5) & (6) & (7) \\
\hline $\begin{array}{l}\text { Lagged relative returns per } \\
\text { sovereign }\end{array}$ & $\begin{array}{l}0.03^{*} \\
(1.80)\end{array}$ & $\begin{array}{l}0.02 \\
(1.32)\end{array}$ & $\begin{array}{l}0.04^{*} \\
(1.98)\end{array}$ & $\begin{array}{l}0.04^{*} \\
(1.98)\end{array}$ & $\begin{array}{l}0.03^{*} \\
(1.77)\end{array}$ & $\begin{array}{l}0.03^{*} \\
(1.79)\end{array}$ & $\begin{array}{l}0.03 \\
(1.62)\end{array}$ \\
\hline $\begin{array}{l}\text { Lagged percentage of sovereign } \\
\text { holding }\end{array}$ & $\begin{array}{l}-1.90^{* * * *} \\
(-3.04)\end{array}$ & $\begin{array}{l}-0.47 \\
(-0.75)\end{array}$ & $\begin{array}{l}-1.41^{* *} \\
(-2.20)\end{array}$ & $\begin{array}{l}-1.77^{* *} \\
(-2.66)\end{array}$ & $\begin{array}{l}-1.33^{* *} \\
(-2.03)\end{array}$ & $\begin{array}{l}-1.56^{* *} \\
(-2.63)\end{array}$ & $\begin{array}{l}-0.37 \\
(-0.70)\end{array}$ \\
\hline Inflation & $\begin{array}{l}-0.89^{* * *} \\
(-12.00)\end{array}$ & $\begin{array}{l}-0.94^{* * *} \\
(-14.29)\end{array}$ & $\begin{array}{l}-0.92^{* * *} \\
(-12.21)\end{array}$ & $\begin{array}{l}-0.92^{* * *} \\
(-12.33)\end{array}$ & $\begin{array}{l}-0.87^{* * *} \\
(-11.72)\end{array}$ & $\begin{array}{l}-0.88^{* * * *} \\
(-12.25)\end{array}$ & $\begin{array}{l}-1.06^{* * * *} \\
(-12.89)\end{array}$ \\
\hline GDP growth & $\begin{array}{l}-0.02 \\
(-0.37)\end{array}$ & $\begin{array}{l}-0.01 \\
(-0.13)\end{array}$ & $\begin{array}{l}-0.01 \\
(-0.24)\end{array}$ & $\begin{array}{l}-0.02 \\
(-0.36)\end{array}$ & $\begin{array}{l}-0.02 \\
(-0.45)\end{array}$ & $\begin{array}{l}0.04 \\
(0.87)\end{array}$ & $\begin{array}{l}0.07 \\
(1.59)\end{array}$ \\
\hline $\begin{array}{l}\text { Logarithm of the sovereign bond } \\
\text { market }\end{array}$ & $\begin{array}{l}-2.60^{* * *} \\
(-23.69)\end{array}$ & $\begin{array}{l}-2.47^{* * * *} \\
(-26.67)\end{array}$ & $\begin{array}{l}-2.62^{* * * *} \\
(-30.80)\end{array}$ & $\begin{array}{l}-2.66^{* * *} \\
(-28.74)\end{array}$ & $\begin{array}{l}-2.70^{* * * *} \\
(-29.65)\end{array}$ & $\begin{array}{l}-2.59^{* * * *} \\
(-30.33)\end{array}$ & $\begin{array}{l}-2.40^{\text {**** }} \\
(-28.40)\end{array}$ \\
\hline VIX index & $\begin{array}{l}-0.03^{* * *} \\
(-4.27)\end{array}$ & $\begin{array}{l}-0.01^{*} \\
(-1.92)\end{array}$ & $\begin{array}{l}-0.03^{* * * *} \\
(-3.38)\end{array}$ & $\begin{array}{l}-0.04^{* * *} \\
(-5.08)\end{array}$ & $\begin{array}{l}-0.03^{* * *} \\
(-4.11)\end{array}$ & $\begin{array}{l}-0.02^{* *} \\
(-2.20)\end{array}$ & $\begin{array}{l}-0.01 \\
(-0.84)\end{array}$ \\
\hline Rating & $\begin{array}{l}-0.47^{* * * *} \\
(-4.45)\end{array}$ & $\begin{array}{l}-0.19^{* *} \\
(-2.62)\end{array}$ & $\begin{array}{l}-0.78^{* * *} \\
(-12.61)\end{array}$ & $\begin{array}{l}-0.74^{* * *} \\
(-11.37)\end{array}$ & $\begin{array}{l}-0.62^{* * * *} \\
(-10.19)\end{array}$ & $\begin{array}{l}-0.40^{* * *} \\
(-5.24)\end{array}$ & $\begin{array}{l}-0.21^{* *} \\
(-2.31)\end{array}$ \\
\hline Control of corruption & $\begin{array}{l}2.32^{* * * *} \\
(6.02)\end{array}$ & & & & & & $\begin{array}{l}-0.89 \\
(-0.77)\end{array}$ \\
\hline Government effectiveness & & $\begin{array}{l}4.80^{* * * *} \\
(15.52)\end{array}$ & & & & & $\begin{array}{l}8.42^{* * * *} \\
(9.10)\end{array}$ \\
\hline $\begin{array}{l}\text { Political stability and absence of } \\
\text { violence/terrorism }\end{array}$ & & & $\begin{array}{l}1.62^{* * * *} \\
(4.20)\end{array}$ & & & & $\begin{array}{l}-0.19 \\
(-0.52)\end{array}$ \\
\hline Regulatory quality & & & & $\begin{array}{l}2.33^{\text {**** }} \\
(4.69)\end{array}$ & & & $\begin{array}{l}-2.04 \\
(-1.57)\end{array}$ \\
\hline Rule of law & & & & & $\begin{array}{l}2.10^{* * * *} \\
(8.02)\end{array}$ & & $\begin{array}{l}-6.44^{\text {***k }} \\
(-10.04)\end{array}$ \\
\hline Voice and accountability & & & & & & $\begin{array}{l}5.26^{* * * *} \\
(9.01)\end{array}$ & $\begin{array}{l}9.29^{* * * *} \\
(9.39)\end{array}$ \\
\hline Constant & $\begin{array}{l}82.04^{\text {*k** }} \\
(22.44)\end{array}$ & 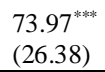 & $\begin{array}{l}85.62^{\text {****k }} \\
(35.70)\end{array}$ & $\begin{array}{l}84.93^{\text {***k }} \\
(30.81)\end{array}$ & $\begin{array}{l}85.55^{\text {***** }} \\
(35.14)\end{array}$ & $\begin{array}{l}77.97^{\text {***k }} \\
(34.05)\end{array}$ & $\begin{array}{l}68.54^{\text {**:k }} \\
(29.37)\end{array}$ \\
\hline Country-pension fund fixed-effects & No & No & No & No & No & No & No \\
\hline Time fixed-effects & No & No & No & No & No & No & No \\
\hline Observations & 18294 & 18294 & 18294 & 18294 & 18294 & 18294 & 18294 \\
\hline Adjusted $R^{2}$ & 0.13 & 0.14 & 0.13 & 0.13 & 0.13 & 0.13 & 0.14 \\
\hline
\end{tabular}

$t$ statistics in parentheses, ${ }^{*} p<0.10,{ }^{* *} p<0.05,{ }^{* * *} p<0.01$ 


\section{(table continued)}

\begin{tabular}{|c|c|c|c|c|c|c|}
\hline $\begin{array}{l}\text { LSDV } \\
(8) \\
\end{array}$ & (9) & (10) & (11) & (12) & (13) & (14) \\
\hline 0.02 & 0.02 & 0.02 & 0.02 & 0.02 & 0.02 & 0.01 \\
\hline (0.97) & $(0.95)$ & $(0.79)$ & $(0.80)$ & $(0.87)$ & $(0.85)$ & $(0.34)$ \\
\hline $\begin{array}{l}1.57 \\
(1.32)\end{array}$ & $\begin{array}{l}1.05 \\
(0.84)\end{array}$ & $\begin{array}{l}2.46^{*} \\
(1.95)\end{array}$ & $\begin{array}{l}0.38 \\
(0.33)\end{array}$ & $\begin{array}{l}1.66 \\
(1.39)\end{array}$ & $\begin{array}{l}-1.27 \\
(-1.28)\end{array}$ & $\begin{array}{l}-0.85 \\
(-0.89)\end{array}$ \\
\hline $\begin{array}{l}-1.15^{* * * *} \\
(-8.05)\end{array}$ & $\begin{array}{l}-1.18^{* * * *} \\
(-7.78)\end{array}$ & $\begin{array}{l}-1.21^{\text {**** }} \\
(-9.48)\end{array}$ & $\begin{array}{l}-1.15^{\text {**** }} \\
(-7.86)\end{array}$ & $\begin{array}{l}-1.09^{* * *} \\
(-7.55)\end{array}$ & $\begin{array}{l}-1.35^{\text {**** }} \\
(-9.40)\end{array}$ & $\begin{array}{l}-1.28^{\text {**** }} \\
(-9.58)\end{array}$ \\
\hline $\begin{array}{l}-0.11^{*} \\
(-1.73)\end{array}$ & $\begin{array}{l}-0.12^{* *} \\
(-2.04)\end{array}$ & $\begin{array}{l}-0.18^{\text {**** }} \\
(-2.89)\end{array}$ & $\begin{array}{l}-0.14^{\text {*** }} \\
(-2.40)\end{array}$ & $\begin{array}{l}-0.16^{* *} \\
(-2.60)\end{array}$ & $\begin{array}{l}-0.07 \\
(-1.34)\end{array}$ & $\begin{array}{l}-0.27^{\text {**** }} \\
(-4.42)\end{array}$ \\
\hline $\begin{array}{l}-4.66^{* * * * *} \\
(-3.15)\end{array}$ & $\begin{array}{l}-5.43^{\text {**** }} \\
(-3.81)\end{array}$ & $\begin{array}{l}-5.38^{\text {*** }} \\
(-3.61)\end{array}$ & $\begin{array}{l}-4.91^{\text {**** }} \\
(-3.68)\end{array}$ & $\begin{array}{l}-5.67^{* * *} \\
(-3.59)\end{array}$ & $\begin{array}{l}-3.20^{\text {*** }} \\
(-2.23)\end{array}$ & $\begin{array}{l}-6.42^{\text {**** }} \\
(-4.90)\end{array}$ \\
\hline $\begin{array}{l}0.03 \\
(1.20)\end{array}$ & $\begin{array}{l}0.02 \\
(0.80)\end{array}$ & $\begin{array}{l}-0.02 \\
(-0.82)\end{array}$ & $\begin{array}{l}0.02 \\
(0.71)\end{array}$ & $\begin{array}{l}0.02 \\
(0.65)\end{array}$ & $\begin{array}{l}0.08^{* * * *} \\
(2.72)\end{array}$ & $\begin{array}{l}-0.04 \\
(-1.61)\end{array}$ \\
\hline $\begin{array}{l}0.98^{* * * *} \\
(8.04)\end{array}$ & $\begin{array}{l}0.92^{* * *} \\
(6.99)\end{array}$ & $\begin{array}{l}0.99^{* * * *} \\
(10.53)\end{array}$ & $\begin{array}{l}1.42^{* * * *} \\
(9.07)\end{array}$ & $\begin{array}{l}0.72^{\text {**** }} \\
(5.82)\end{array}$ & $\begin{array}{l}1.69^{* * * *} \\
(12.16)\end{array}$ & $\begin{array}{l}1.56^{\text {**** }} \\
(8.95)\end{array}$ \\
\hline \multirow[t]{6}{*}{$\begin{array}{l}0.68 \\
(0.64)\end{array}$} & & & & & & $\begin{array}{l}1.18 \\
(1.60)\end{array}$ \\
\hline & $\begin{array}{l}7.44^{\text {**** }} \\
(3.34)\end{array}$ & & & & & $\begin{array}{l}10.74^{\text {**** }} \\
(7.14)\end{array}$ \\
\hline & & $\begin{array}{l}-10.51^{\text {**** }} \\
(-7.89)\end{array}$ & & & & $\begin{array}{l}-11.88^{\text {****k }} \\
(-10.55)\end{array}$ \\
\hline & & & $\begin{array}{l}11.51^{* * * *} \\
(8.10)\end{array}$ & & & $\begin{array}{l}10.46^{* * * *} \\
(5.02)\end{array}$ \\
\hline & & & & $\begin{array}{l}-12.13^{* * * *} \\
(-6.85)\end{array}$ & & $\begin{array}{l}-16.83^{\text {***k }} \\
(-7.72)\end{array}$ \\
\hline & & & & & 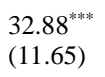 & $\begin{array}{l}21.77^{* * * *} \\
(8.03)\end{array}$ \\
\hline $\begin{array}{l}81.35^{\text {** }} \\
(2.39)\end{array}$ & $\begin{array}{l}98.21^{\text {***k }} \\
(2.99)\end{array}$ & $\begin{array}{l}101.64^{\text {**** }} \\
(3.03)\end{array}$ & $\begin{array}{l}76.62^{\text {*** }} \\
(2.46)\end{array}$ & 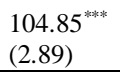 & $\begin{array}{l}27.45 \\
(0.83)\end{array}$ & $\begin{array}{l}102.76^{\text {冰冰 }} \\
(3.34)\end{array}$ \\
\hline Yes & Yes & Yes & Yes & Yes & Yes & Yes \\
\hline Yes & Yes & Yes & Yes & Yes & Yes & Yes \\
\hline 18294 & 18294 & 18294 & 18294 & 18294 & 18294 & 18294 \\
\hline 0.28 & 0.28 & 0.29 & 0.28 & 0.28 & 0.29 & 0.29 \\
\hline
\end{tabular}




\section{Table 24. Sell herd behaviour and institutional factors}

This table represents the results of the ordinary least squares regressions (OLS) and least squares dummy variable regressions (LSDV) of the LSV herding measure corrected by the prevailing interest rate. Errors are clustered at the country level and at the month level.

\begin{tabular}{|c|c|c|c|c|c|c|c|}
\hline & $\begin{array}{l}\text { OLS } \\
(1)\end{array}$ & (2) & (3) & (4) & (5) & (6) & (7) \\
\hline $\begin{array}{l}\text { Lagged relative returns per } \\
\text { sovereign }\end{array}$ & $\begin{array}{l}-0.01 \\
(-0.43)\end{array}$ & $\begin{array}{l}-0.01 \\
(-0.52)\end{array}$ & $\begin{array}{l}-0.01 \\
(-0.44)\end{array}$ & $\begin{array}{l}-0.01 \\
(-0.34)\end{array}$ & $\begin{array}{l}-0.01 \\
(-0.52)\end{array}$ & $\begin{array}{l}-0.02 \\
(-0.53)\end{array}$ & $\begin{array}{l}-0.00 \\
(-0.21)\end{array}$ \\
\hline $\begin{array}{l}\text { Lagged percentage of sovereign } \\
\text { holding }\end{array}$ & $\begin{array}{l}-3.84^{* * * k} \\
(-4.16)\end{array}$ & $\begin{array}{l}-6.61^{* * * *} \\
(-6.94)\end{array}$ & $\begin{array}{l}-4.01^{\text {***k }} \\
(-4.21)\end{array}$ & $\begin{array}{l}-6.65^{\text {***k }} \\
(-7.89)\end{array}$ & $\begin{array}{l}-5.78^{* * *} \\
(-6.55)\end{array}$ & $\begin{array}{l}-4.27^{\text {**** }} \\
(-4.40)\end{array}$ & $\begin{array}{l}-10.47^{\text {**** }} \\
(-15.57)\end{array}$ \\
\hline Inflation & $\begin{array}{l}0.50^{* * * *} \\
(3.85)\end{array}$ & $\begin{array}{l}0.37^{* * * *} \\
(2.87)\end{array}$ & $\begin{array}{l}0.48^{* * *} \\
(3.78)\end{array}$ & $\begin{array}{l}0.22^{*} \\
(1.90)\end{array}$ & $\begin{array}{l}0.38^{* * *} \\
(2.89)\end{array}$ & $\begin{array}{l}0.47^{* * * *} \\
(3.78)\end{array}$ & $\begin{array}{l}0.06 \\
(0.70)\end{array}$ \\
\hline GDP growth & $\begin{array}{l}0.30^{* * * *} \\
(3.84)\end{array}$ & $\begin{array}{l}0.22^{* * * *} \\
(2.77)\end{array}$ & $\begin{array}{l}0.28^{* * *} \\
(3.54)\end{array}$ & $\begin{array}{l}0.13 \\
(1.61)\end{array}$ & $\begin{array}{l}0.25^{\text {**** }} \\
(3.04)\end{array}$ & $\begin{array}{l}0.18^{* *} \\
(2.15)\end{array}$ & $\begin{array}{l}-0.09 \\
(-1.41)\end{array}$ \\
\hline $\begin{array}{l}\text { Logarithm of the sovereign bond } \\
\text { market }\end{array}$ & $\begin{array}{l}-1.00^{* * * *} \\
(-7.20)\end{array}$ & $\begin{array}{l}-1.40^{* * * *} \\
(-10.72)\end{array}$ & $\begin{array}{l}-1.00^{* * *} \\
(-7.50)\end{array}$ & $\begin{array}{l}-1.66^{* * * *} \\
(-13.21)\end{array}$ & $\begin{array}{l}-1.08^{* * * *} \\
(-8.62)\end{array}$ & $\begin{array}{l}-1.01^{\text {**** }} \\
(-8.57)\end{array}$ & $\begin{array}{l}-0.82^{\text {**** }} \\
(-6.55)\end{array}$ \\
\hline VIX index & $\begin{array}{l}0.10^{* * * *} \\
(3.98)\end{array}$ & $\begin{array}{l}0.05^{* *} \\
(2.04)\end{array}$ & $\begin{array}{l}0.09^{* * *} \\
(3.57)\end{array}$ & $\begin{array}{l}0.03 \\
(1.00)\end{array}$ & $\begin{array}{l}0.06^{* * *} \\
(2.38)\end{array}$ & $\begin{array}{l}0.07^{* * * *} \\
(2.75)\end{array}$ & $\begin{array}{l}0.02 \\
(0.94)\end{array}$ \\
\hline Rating & $\begin{array}{l}1.04^{\text {**** }} \\
(12.73)\end{array}$ & $\begin{array}{l}-0.17 \\
(-1.21)\end{array}$ & $\begin{array}{l}1.00^{* * *} \\
(14.51)\end{array}$ & $\begin{array}{l}-0.43^{\text {*** }} \\
(-4.34)\end{array}$ & $\begin{array}{l}0.29^{* * * *} \\
(3.12)\end{array}$ & $\begin{array}{l}0.46^{* * *} \\
(8.08)\end{array}$ & $\begin{array}{l}-0.20^{*} \\
(-1.75)\end{array}$ \\
\hline Control of corruption & $\begin{array}{l}-0.44 \\
(-1.07)\end{array}$ & & & & & & $\begin{array}{l}22.74^{\text {***k }} \\
(22.13)\end{array}$ \\
\hline Government effectiveness & & $\begin{array}{l}-7.64^{* * *} \\
(-7.76)\end{array}$ & & & & & $\begin{array}{l}-19.00^{* * *} \\
(-24.84)\end{array}$ \\
\hline $\begin{array}{l}\text { Political stability and absence of } \\
\text { violence/terrorism }\end{array}$ & & & $\begin{array}{l}-1.16^{* * * *} \\
(-3.64)\end{array}$ & & & & $\begin{array}{l}8.12^{* * *} \\
(11.28)\end{array}$ \\
\hline Regulatory quality & & & & $\begin{array}{l}-11.75^{* * * *} \\
(-14.25)\end{array}$ & & & $\begin{array}{l}-18.83^{\text {**** }} \\
(-20.32)\end{array}$ \\
\hline Rule of law & & & & & $\begin{array}{l}-4.39^{* * *} \\
(-7.20)\end{array}$ & & $\begin{array}{l}-0.95 \\
(-0.65)\end{array}$ \\
\hline Voice and accountability & & & & & & $\begin{array}{l}-6.12^{* * *} \\
(-12.16)\end{array}$ & $\begin{array}{l}-13.33^{* * *} \\
(-10.27)\end{array}$ \\
\hline Constant & $\begin{array}{l}28.36^{\text {**** }} \\
(7.08)\end{array}$ & $\begin{array}{l}53.73^{* * * *} \\
(12.31)\end{array}$ & $\begin{array}{l}29.04^{* * * *} \\
(8.05)\end{array}$ & $\begin{array}{l}68.16^{* * * *} \\
(15.80)\end{array}$ & $\begin{array}{l}39.02^{\text {***** }} \\
(11.29)\end{array}$ & $\begin{array}{l}38.00^{* * * *} \\
(12.10)\end{array}$ & $\begin{array}{l}61.81^{\text {***k }} \\
(15.20)\end{array}$ \\
\hline Country-pension fund fixed-effects & No & No & No & No & No & No & No \\
\hline Time fixed-effects & No & No & No & No & No & No & No \\
\hline Observations & 8284 & 8284 & 8284 & 8284 & 8284 & 8284 & 8284 \\
\hline Adjusted $R^{2}$ & 0.19 & 0.21 & 0.19 & 0.24 & 0.20 & 0.20 & 0.35 \\
\hline
\end{tabular}

$t$ statistics in parentheses, ${ }^{*} p<0.10,{ }^{* *} p<0.05,{ }^{* * *} p<0.01$ 
(table continued)

\begin{tabular}{|c|c|c|c|c|c|c|}
\hline $\begin{array}{l}\text { LSDV } \\
(8)\end{array}$ & (9) & (10) & (11) & (12) & (13) & (14) \\
\hline $\begin{array}{l}-0.01 \\
(-0.53)\end{array}$ & $\begin{array}{l}-0.01 \\
(-0.47)\end{array}$ & $\begin{array}{l}-0.01 \\
(-0.43)\end{array}$ & $\begin{array}{l}-0.01 \\
(-0.41)\end{array}$ & $\begin{array}{l}-0.01 \\
(-0.27)\end{array}$ & $\begin{array}{l}-0.01 \\
(-0.44)\end{array}$ & $\begin{array}{l}-0.00 \\
(-0.13)\end{array}$ \\
\hline $\begin{array}{l}-4.91^{\text {**** }} \\
(-3.04)\end{array}$ & $\begin{array}{l}-5.13^{\text {**** }} \\
(-3.17)\end{array}$ & $\begin{array}{l}-4.99^{* * * k} \\
(-3.30)\end{array}$ & $\begin{array}{l}-4.19^{* *} \\
(-2.44)\end{array}$ & $\begin{array}{l}-4.30^{* * *} \\
(-2.71)\end{array}$ & $\begin{array}{l}-4.80^{\text {***⿰㇇⿰亅⿱丿丶丶 }} \\
(-2.96)\end{array}$ & $\begin{array}{l}-0.87 \\
(-0.46)\end{array}$ \\
\hline $\begin{array}{l}-0.09 \\
(-0.67)\end{array}$ & $\begin{array}{l}-0.09 \\
(-0.64)\end{array}$ & $\begin{array}{l}-0.08 \\
(-0.55)\end{array}$ & $\begin{array}{l}-0.07 \\
(-0.53)\end{array}$ & $\begin{array}{l}-0.33^{* *} \\
(-2.59)\end{array}$ & $\begin{array}{l}-0.07 \\
(-0.52)\end{array}$ & $\begin{array}{l}-0.40^{\text {**** }} \\
(-2.79)\end{array}$ \\
\hline $\begin{array}{l}-0.17 \\
(-1.57)\end{array}$ & $\begin{array}{l}-0.16 \\
(-1.62)\end{array}$ & $\begin{array}{l}-0.18^{*} \\
(-1.90)\end{array}$ & $\begin{array}{l}-0.12 \\
(-1.27)\end{array}$ & $\begin{array}{l}-0.01 \\
(-0.12)\end{array}$ & $\begin{array}{l}-0.16 \\
(-1.57)\end{array}$ & $\begin{array}{l}0.06 \\
(0.64)\end{array}$ \\
\hline $\begin{array}{l}-11.10^{* * * *} \\
(-4.16)\end{array}$ & $\begin{array}{l}-10.93^{\text {**** }} \\
(-3.95)\end{array}$ & $\begin{array}{l}-10.81^{\text {**** }} \\
(-4.14)\end{array}$ & $\begin{array}{l}-8.59^{* *} \\
(-2.63)\end{array}$ & $\begin{array}{l}-15.31^{\text {***** }} \\
(-5.77)\end{array}$ & $\begin{array}{l}-10.53^{* * * *} \\
(-4.01)\end{array}$ & $\begin{array}{l}-13.17^{\text {**a*k }} \\
(-4.24)\end{array}$ \\
\hline $\begin{array}{l}-0.03 \\
(-0.77)\end{array}$ & $\begin{array}{l}-0.04 \\
(-0.95)\end{array}$ & $\begin{array}{l}-0.02 \\
(-0.53)\end{array}$ & $\begin{array}{l}-0.02 \\
(-0.48)\end{array}$ & $\begin{array}{l}-0.04 \\
(-0.94)\end{array}$ & $\begin{array}{l}-0.04 \\
(-0.91)\end{array}$ & $\begin{array}{l}0.05 \\
(1.03)\end{array}$ \\
\hline $\begin{array}{l}0.43^{* * * *} \\
(3.14)\end{array}$ & $\begin{array}{l}0.52^{* * *} \\
(3.33)\end{array}$ & $\begin{array}{l}0.59^{* * * *} \\
(4.13)\end{array}$ & $\begin{array}{l}0.10 \\
(0.45)\end{array}$ & $\begin{array}{l}1.15^{\text {**** }} \\
(7.94)\end{array}$ & $\begin{array}{l}0.45^{\text {**** }} \\
(2.82)\end{array}$ & $\begin{array}{l}0.40^{*} \\
(1.91)\end{array}$ \\
\hline \multirow[t]{6}{*}{$\begin{array}{l}-3.82^{*} \\
(-1.93)\end{array}$} & & & & & & $\begin{array}{l}-10.16^{\text {**** }} \\
(-4.65)\end{array}$ \\
\hline & $\begin{array}{l}1.01 \\
(0.45)\end{array}$ & & & & & $\begin{array}{l}-2.28 \\
(-1.05)\end{array}$ \\
\hline & & $\begin{array}{l}6.84^{\text {**** }} \\
(6.95)\end{array}$ & & & & $\begin{array}{l}8.94^{* * * *} \\
(8.64)\end{array}$ \\
\hline & & & $\begin{array}{l}-9.22^{\text {***k }} \\
(-2.91)\end{array}$ & & & $\begin{array}{l}-18.41^{\text {****k }} \\
(-4.89)\end{array}$ \\
\hline & & & & $\begin{array}{l}29.70^{* * * *} \\
(11.49)\end{array}$ & & $\begin{array}{l}45.20^{\text {**** }} \\
(15.23)\end{array}$ \\
\hline & & & & & $\begin{array}{l}-3.39 \\
(-1.48)\end{array}$ & $\begin{array}{l}-6.15 \\
(-1.58)\end{array}$ \\
\hline $\begin{array}{l}293.00^{* * * *} \\
(4.73)\end{array}$ & $\begin{array}{l}240.53^{\text {*** }} \\
(3.83)\end{array}$ & $\begin{array}{l}229.94^{* * * *} \\
(3.75)\end{array}$ & $\begin{array}{l}286.32^{\text {***k }} \\
(3.01)\end{array}$ & $\begin{array}{l}434.52^{\text {****k }} \\
(5.44)\end{array}$ & $\begin{array}{l}238.45^{\text {*** }} \\
(3.85)\end{array}$ & $\begin{array}{l}385.07^{\text {*k:k }} \\
(4.17)\end{array}$ \\
\hline Yes & Yes & Yes & Yes & Yes & Yes & Yes \\
\hline Yes & Yes & Yes & Yes & Yes & Yes & Yes \\
\hline 8284 & 8284 & 8284 & 8284 & 8284 & 8284 & 8284 \\
\hline 0.57 & 0.57 & 0.57 & 0.57 & 0.57 & 0.57 & 0.58 \\
\hline
\end{tabular}




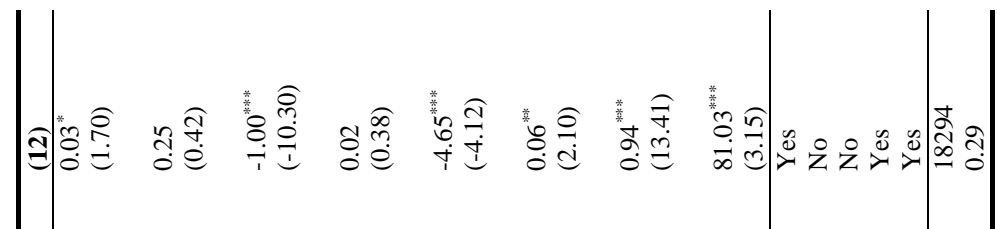

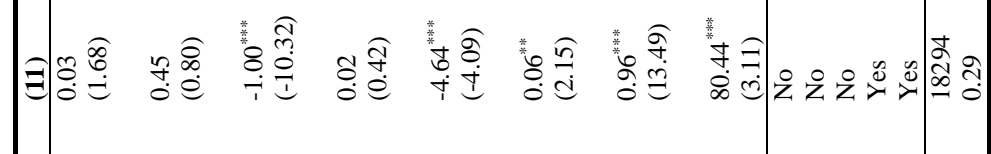

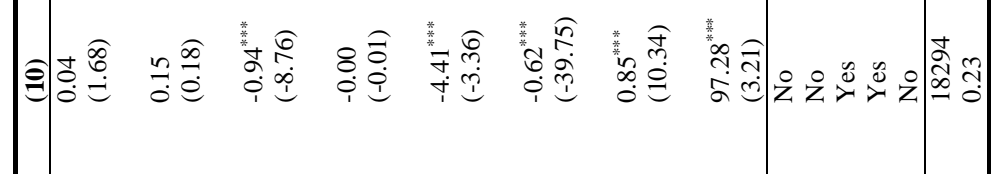

句高要

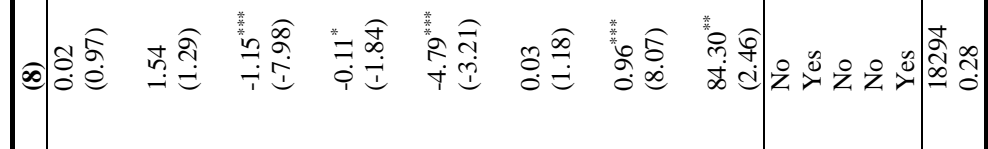

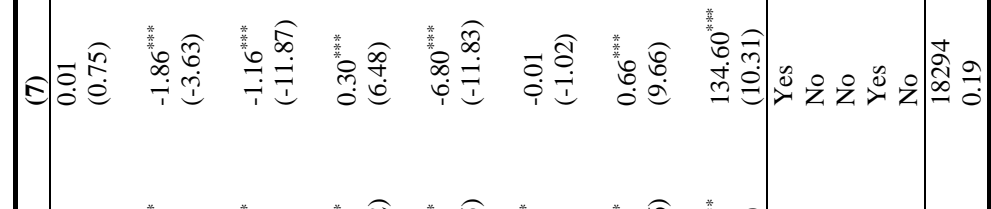

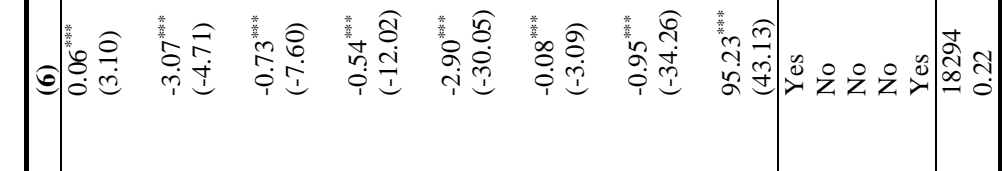

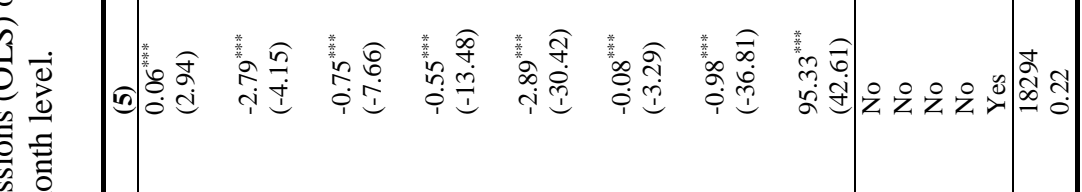

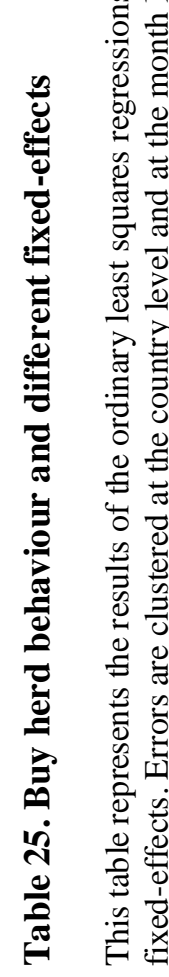

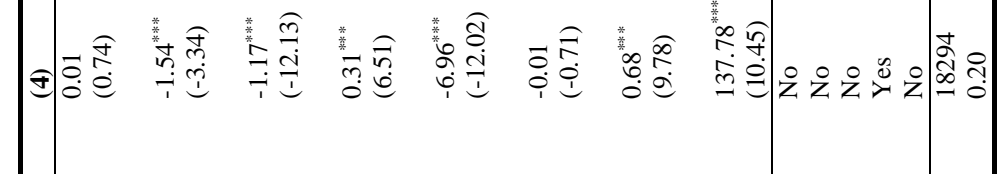

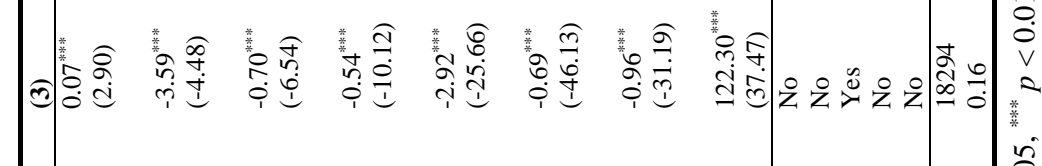

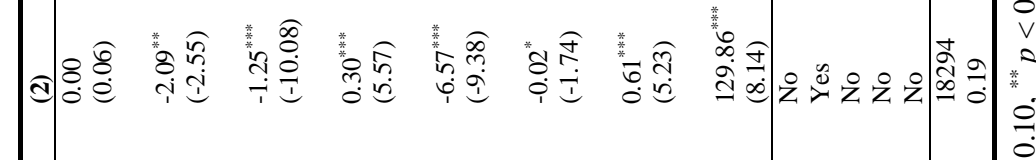

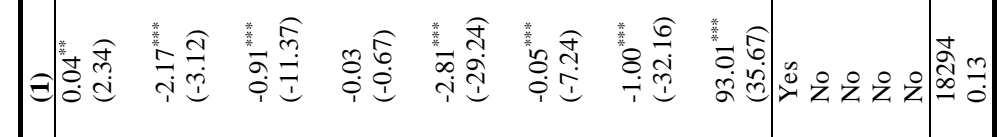

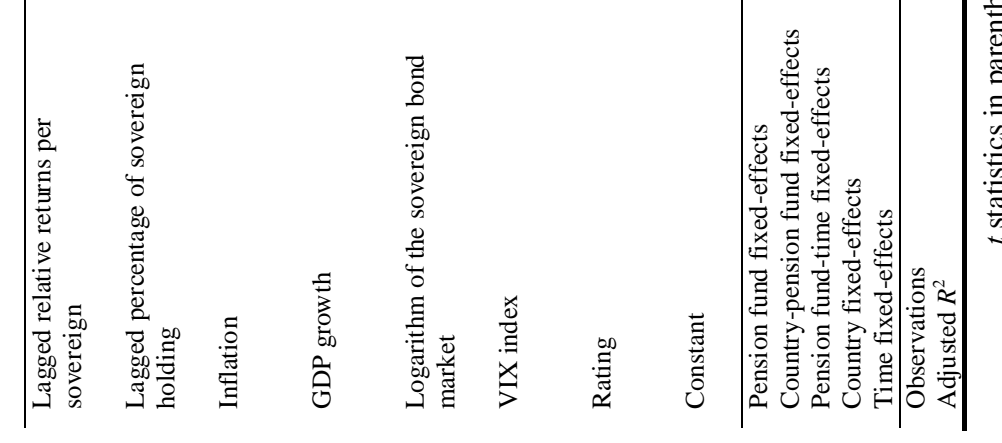




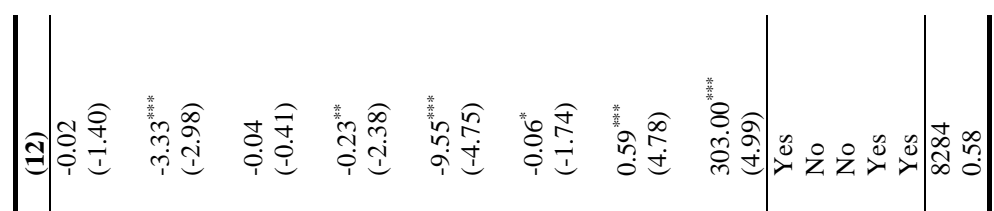

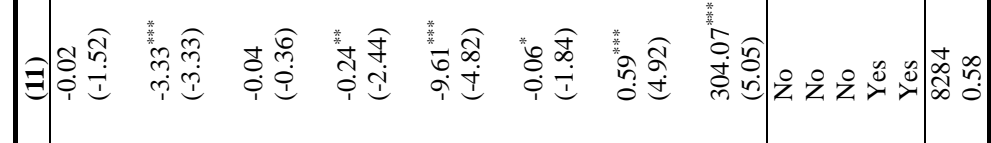

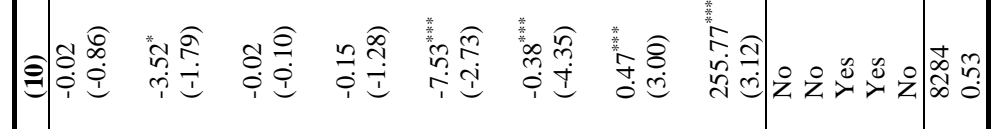

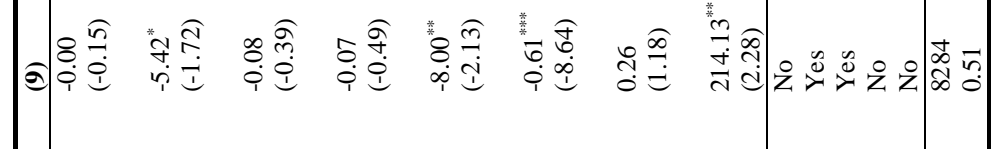

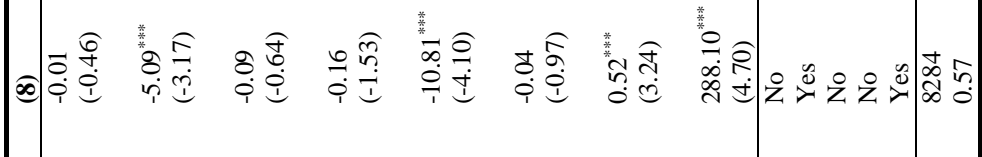

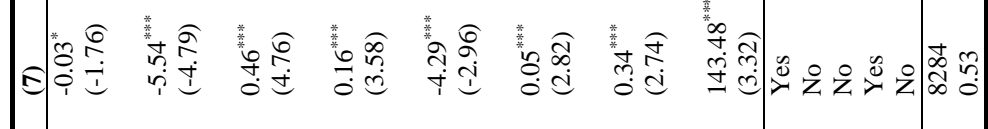

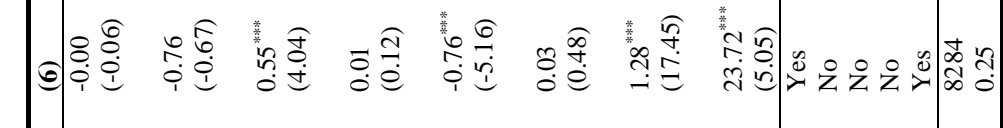

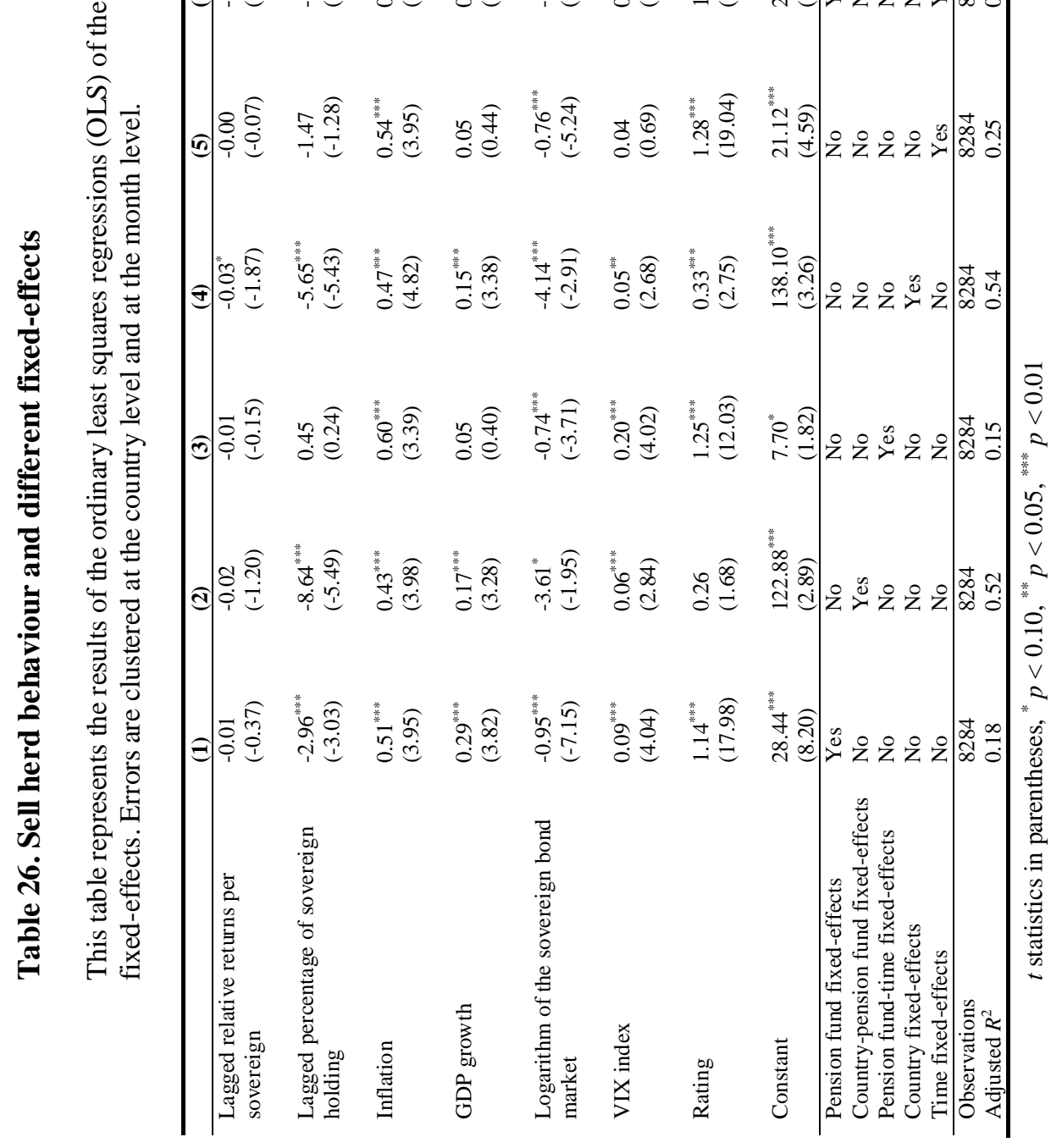


Figure 7. Three-month moving-average LSV herding measure in the period December 2008December 2014

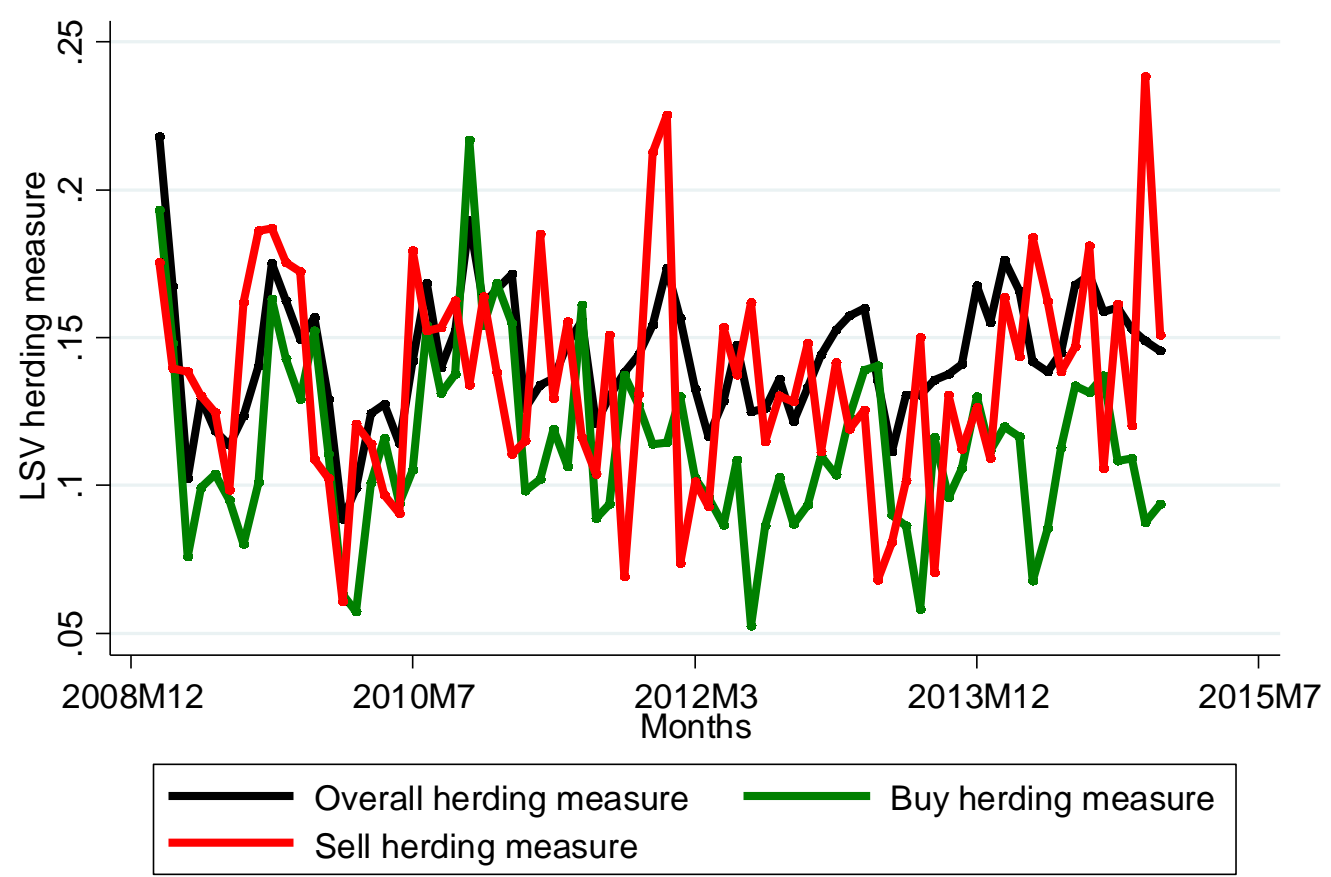

Source: Own calculations. 


\section{Table 27. Total return reversals per quintile}

This table reveals whether return reversals are present. For each month, the buy and sell herding measures are divided in quintiles for the month in which pension funds buy or sell long-term sovereign bonds (in this case, at $a r$ ). The highest quintile (5) represents the most intensive buy or sell herding, whereas the lowest quintile (1) shows the least intensive buy or sell herding. The return consists of price changes and exchange rate changes. The returns are subtracted by the average monthly return. This calculation gives the ar which is the abnormal return. The table shows whether the abnormal return is significantly different from zero for the two months prior to the buy or sell month $\left(a r_{t-2}\right.$ and $\left.a r_{t-1}\right)$, and for the five months after the buy or sell month $\left(a r_{t+1}, \ldots, a r_{t+5}\right)$. The $t$ statistics are in parentheses.

\begin{tabular}{|c|c|c|c|c|c|c|c|c|}
\hline Quintile & $a r_{t-2}$ & $a r_{t-1}$ & $a r$ & $a r_{t+1}$ & $a r_{t+2}$ & $a r_{t+3}$ & $a r_{t+4}$ & $a r_{t+5}$ \\
\hline \multicolumn{9}{|c|}{ Sell herding } \\
\hline \multirow[t]{2}{*}{ S5 } & 0.067 & 0.520 & 1.224 & 0.479 & 0.648 & -0.191 & -0.602 & -0.364 \\
\hline & $(0.335)$ & (2.646) & $(4.672)$ & (1.998) & (3.088) & $(-0.921)$ & $(-2.565)$ & $(-1.359)$ \\
\hline \multirow[t]{2}{*}{ S4 } & -0.289 & 1.033 & -0.235 & 0.638 & -0.218 & 0.333 & -0.067 & 0.506 \\
\hline & $(-1.532)$ & (4.612) & $(-1.363)$ & (3.009) & $(-1.111)$ & (1.494) & $(-0.333)$ & (2.609) \\
\hline \multirow[t]{2}{*}{ S3 } & 0.122 & -0.520 & 0.434 & -0.458 & 0.301 & -0.134 & 0.885 & -0.016 \\
\hline & $(0.713)$ & $(-2.885)$ & $(1.861)$ & $(-3.035)$ & (1.315) & $(-0.999)$ & (3.484) & $(-0.143)$ \\
\hline \multirow[t]{2}{*}{$\mathrm{S} 2$} & 0.093 & 0.204 & -0.299 & -0.424 & 0.240 & -0.282 & -0.158 & 0.505 \\
\hline & $(0.710)$ & $(0.964)$ & $(-2.099)$ & $(-2.820)$ & (1.217) & $(-2.497)$ & $(-0.795)$ & $(2.525)$ \\
\hline \multirow[t]{2}{*}{$\mathrm{S} 1$} & -0.119 & 0.343 & 0.243 & -0.392 & -0.309 & -0.263 & 0.163 & -0.319 \\
\hline & $(-2.625)$ & $(2.146)$ & $(1.762)$ & $(-2.992)$ & $(-2.296)$ & $(-2.667)$ & $(1.082)$ & $(-2.625)$ \\
\hline \multicolumn{9}{|c|}{ Buy herding } \\
\hline \multirow[t]{2}{*}{ B5 } & -0.309 & 0.183 & -0.091 & 0.116 & -0.173 & 0.099 & -0.255 & -0.117 \\
\hline & $(-2.722)$ & (1.221) & $(-0.930)$ & $(0.895)$ & $(-1.526)$ & (1.079) & $(-3.336)$ & $(-0.955)$ \\
\hline \multirow[t]{2}{*}{ B4 } & -0.136 & 0.010 & 0.050 & -0.239 & -0.112 & 0.029 & -0.078 & -0.174 \\
\hline & $(-1.324)$ & $(0.102)$ & $(0.436)$ & $(-2.479)$ & $(-1.554)$ & $(0.318)$ & $(-0.902)$ & $(-1.947)$ \\
\hline \multirow[t]{2}{*}{ B3 } & 0.049 & -0.226 & -0.064 & -0.080 & -0.391 & -0.142 & -0.267 & -0.025 \\
\hline & $(0.468)$ & $(-1.904)$ & $(-0.485)$ & $(-0.740)$ & $(-4.078)$ & $(-1.141)$ & $(-2.756)$ & $(-0.221)$ \\
\hline \multirow[t]{2}{*}{ B2 } & -0.087 & -0.177 & 0.174 & 0.021 & 0.171 & -0.192 & 0.017 & 0.018 \\
\hline & $(-0.681)$ & $(-2.603)$ & (1.440) & $(0.208)$ & (2.589) & $(-3.599)$ & $(0.241)$ & $(0.248)$ \\
\hline \multirow[t]{2}{*}{ B1 } & 0.213 & -0.178 & 0.014 & 0.091 & -0.035 & 0.089 & -0.353 & -0.086 \\
\hline & (1.428) & $(-1.390)$ & $(0.094)$ & $(0.796)$ & $(-0.282)$ & $(0.647)$ & $(-3.967)$ & $(-0.606)$ \\
\hline
\end{tabular}

$t$ statistics in parentheses 


\section{Table 28. Price return reversals per quintile}

This table reveals whether return reversals are present. For each month, the buy and sell herding measures are divided in quintiles for the month in which pension funds buy or sell long-term sovereign bonds (in this case, at $a r$ ). The highest quintile (5) represents the most intensive buy or sell herding, whereas the lowest quintile (1) shows the least intensive buy or sell herding. The return consists of price changes. The returns are subtracted by the average monthly return. This calculation gives the $a r$ which is the abnormal return. The table shows whether the abnormal return is significantly different from zero for the two months prior to the buy or sell month $\left(a r_{t-2}\right.$ and $\left.a r_{t-1}\right)$, and for the five months after the buy or sell month $\left(a r_{t+1}, \ldots, a r_{t+5}\right)$. The $t$ statistics are in parentheses.

\begin{tabular}{|c|c|c|c|c|c|c|c|c|}
\hline Quintile & $a r_{t-2}$ & $a r_{t-1}$ & $a r$ & $a r_{t+1}$ & $a r_{t+2}$ & $a r_{t+3}$ & $a r_{t+4}$ & $a r_{t+5}$ \\
\hline \multicolumn{9}{|c|}{ Sell herding } \\
\hline \multirow[t]{2}{*}{ S5 } & -0.031 & 0.288 & 0.852 & 0.255 & 0.274 & -0.128 & -0.729 & -0.836 \\
\hline & $(-0.178)$ & (1.438) & (5.219) & (1.263) & $(1.540)$ & $(-0.778)$ & $(-3.576)$ & $(-3.706)$ \\
\hline \multirow[t]{2}{*}{ S4 } & -0.141 & 0.855 & 0.368 & 0.398 & -0.227 & 0.394 & -0.387 & 0.435 \\
\hline & $(-0.805)$ & $(5.641)$ & $(2.546)$ & $(2.936)$ & $(-1.461)$ & $(2.292)$ & $(-2.751)$ & (2.646) \\
\hline \multirow[t]{2}{*}{ S3 } & 0.274 & -0.791 & 0.834 & -0.395 & 0.187 & 0.074 & 0.505 & 0.218 \\
\hline & $(2.215)$ & $(-4.891)$ & $(5.396)$ & $(-3.173)$ & $(1.246)$ & $(0.745)$ & (3.073) & $(2.465)$ \\
\hline \multirow[t]{2}{*}{$\mathrm{S} 2$} & 0.126 & 0.021 & 0.190 & -0.194 & 0.330 & -0.185 & -0.133 & 0.477 \\
\hline & (1.433) & $(0.186)$ & (2.327) & $(-1.805)$ & $(2.767)$ & $(-2.946)$ & $(-1.040)$ & $(4.626)$ \\
\hline \multirow[t]{2}{*}{ S1 } & -0.323 & 0.314 & 0.503 & -0.278 & -0.290 & -0.094 & -0.053 & -0.357 \\
\hline & $(-5.191)$ & (3.299) & (6.299) & $(-3.644)$ & $(-2.941)$ & $(-1.224)$ & $(-0.787)$ & $(-5.191)$ \\
\hline \multicolumn{9}{|c|}{ Buy herding } \\
\hline \multirow[t]{2}{*}{ B5 } & -0.027 & 0.208 & 0.005 & -0.007 & 0.051 & 0.086 & 0.140 & -0.076 \\
\hline & $(-0.296)$ & (2.204) & $(0.110)$ & $(-0.116)$ & $(0.868)$ & (1.399) & $(2.628)$ & $(-1.238)$ \\
\hline \multirow[t]{2}{*}{ B4 } & -0.013 & 0.242 & 0.048 & 0.081 & 0.126 & 0.146 & 0.101 & 0.119 \\
\hline & $(-0.291)$ & $(4.515)$ & $(0.720)$ & (1.514) & $(2.431)$ & (3.003) & (2.108) & $(2.224)$ \\
\hline \multirow[t]{2}{*}{ B3 } & 0.025 & -0.112 & -0.199 & 0.038 & -0.236 & -0.056 & 0.090 & 0.027 \\
\hline & $(0.428)$ & $(-1.756)$ & $(-2.187)$ & $(0.760)$ & $(-2.403)$ & $(-0.661)$ & (1.487) & $(0.417)$ \\
\hline \multirow[t]{2}{*}{ B2 } & -0.094 & -0.045 & 0.036 & 0.059 & 0.315 & 0.048 & 0.039 & 0.210 \\
\hline & $(-1.019)$ & $(-1.008)$ & $(0.639)$ & (0.987) & (7.202) & (1.121) & $(0.668)$ & (4.935) \\
\hline \multirow[t]{2}{*}{ B1 } & 0.128 & -0.166 & -0.328 & 0.134 & -0.118 & -0.024 & -0.104 & 0.028 \\
\hline & (1.341) & $(-1.857)$ & $(-3.385)$ & (1.914) & $(-1.624)$ & $(-0.244)$ & $(-1.428)$ & $(0.289)$ \\
\hline
\end{tabular}

$t$ statistics in parentheses 


\section{Table 29. Total return reversals per portfolio}

This table reveals whether return reversals are present by different categories of sovereign bonds: all sovereign bonds, investment grade bonds, noninvestment grade bonds, sovereign bonds from advanced economies and sovereign bonds from emerging and developing economies. For each month, the buy and sell herding measures are divided in quintiles for the month in which pension funds buy or sell long-term sovereign bonds (in this case, at $a r$ ). The highest quintile (5) represents the most intensive buy or sell herding, whereas the lowest quintile (1) shows the least intensive buy or sell herding. The return consists of price changes and exchange rate changes. The returns are subtracted by the average monthly return. This calculation gives the ar which is the abnormal return. Following Cai et al. (2012), we apply a portfolio strategy (e.g. S5-S1) which longs the S5 portfolio and shorts the S1 portfolio. This methodology is also applied for B5-B1 and B5-S5. The table shows whether the abnormal return on an investment portfolio basis is significantly different from zero for the two months prior to the buy or sell month $\left(a r_{t-2}\right.$ and $\left.a r_{t-1}\right)$, and for the five months after the buy or sell month $\left(a r_{t+1}, \ldots, a r_{t+5}\right)$. The $t$ statistics are in parentheses.

\begin{tabular}{|c|c|c|c|c|c|c|c|c|}
\hline Portfolio & $a r_{t-2}$ & $a r_{t-1}$ & $a r$ & $a r_{t+1}$ & $a r_{t+2}$ & $a r_{t+3}$ & $a r_{t+4}$ & $a r_{t+5}$ \\
\hline \multicolumn{9}{|l|}{ All bonds } \\
\hline \multirow[t]{2}{*}{ S5-S1 } & 0.196 & 0.549 & 0.838 & 1.005 & 1.038 & -0.003 & -0.633 & -0.312 \\
\hline & $(12.680)$ & $(41.280)$ & (49.859) & $(56.842)$ & $(59.448)$ & $(-0.221)$ & $(-35.640)$ & $(-12.574)$ \\
\hline \multirow[t]{2}{*}{ B5-B1 } & -0.480 & 0.323 & 0.033 & -0.076 & -0.100 & -0.048 & 0.169 & -0.053 \\
\hline & $(-42.443)$ & $(36.307)$ & $(3.595)$ & $(-7.218)$ & $(-13.507)$ & $(-5.111)$ & $(24.571)$ & $(-5.502)$ \\
\hline \multirow[t]{2}{*}{ B5-S5 } & -0.290 & -0.476 & -1.254 & -0.588 & -0.925 & 0.328 & 0.371 & 0.421 \\
\hline & $(-22.529)$ & $(-29.923)$ & $(-77.569)$ & $(-34.133)$ & $(-57.387)$ & $(24.631)$ & $(20.737)$ & $(17.078)$ \\
\hline \multicolumn{9}{|c|}{ Investment grade bonds } \\
\hline \multirow[t]{2}{*}{ S5-S1 } & 0.179 & 0.550 & 0.817 & 1.023 & 1.032 & -0.025 & -0.652 & -0.324 \\
\hline & $(9.523)$ & $(34.527)$ & $(40.782)$ & $(47.355)$ & $(48.228)$ & $(-1.578)$ & $(-30.877)$ & $(-10.801)$ \\
\hline \multirow[t]{2}{*}{ B5-B 1} & -0.485 & 0.339 & -0.006 & -0.073 & -0.106 & -0.014 & 0.167 & -0.058 \\
\hline & $(-35.838)$ & $(31.463)$ & $(-0.546)$ & $(-5.791)$ & $(-11.803)$ & $(-1.200)$ & $(20.126)$ & $(-5.053)$ \\
\hline \multirow[t]{2}{*}{ B5-S5 } & -0.289 & -0.467 & -1.238 & -0.605 & -0.932 & 0.377 & 0.340 & 0.421 \\
\hline & $(-18.612)$ & $(-24.319)$ & $(-64.328)$ & $(-28.894)$ & $(-47.366)$ & $(23.526)$ & $(15.850)$ & $(14.102)$ \\
\hline \multicolumn{9}{|c|}{ Noninvestment grade bonds } \\
\hline \multirow[t]{2}{*}{ S5-S1 } & 0.238 & 0.546 & 0.889 & 0.962 & 1.052 & 0.049 & -0.590 & -0.283 \\
\hline & $(8.747)$ & $(22.630)$ & $(28.734)$ & $(31.541)$ & $(35.166)$ & $(2.015)$ & $(-17.945)$ & $(-6.446)$ \\
\hline \multirow[t]{2}{*}{ B5-B1 } & -0.471 & 0.286 & 0.125 & -0.084 & -0.087 & -0.129 & 0.173 & -0.041 \\
\hline & $(-22.739)$ & $(18.160)$ & $(7.588)$ & $(-4.327)$ & $(-6.600)$ & $(-7.583)$ & (14.138) & $(-2.331)$ \\
\hline \multirow[t]{2}{*}{ B5-S5 } & -0.292 & -0.497 & -1.290 & -0.548 & -0.908 & 0.215 & 0.441 & 0.420 \\
\hline & $(-12.733)$ & $(-17.552)$ & $(-43.356)$ & $(-18.174)$ & $(-32.554)$ & $(8.962)$ & $(13.680)$ & $(9.654)$ \\
\hline \multicolumn{9}{|c|}{ Advanced economies } \\
\hline \multirow[t]{2}{*}{ S5-S1 } & 0.136 & 0.551 & 0.797 & 1.051 & 1.032 & -0.031 & -0.681 & -0.301 \\
\hline & $(5.908)$ & $(28.469)$ & $(33.156)$ & $(39.457)$ & $(38.875)$ & $(-1.594)$ & $(-27.126)$ & $(-8.402)$ \\
\hline \multirow[t]{2}{*}{ B5-B 1} & -0.499 & 0.377 & -0.065 & -0.068 & -0.117 & 0.041 & 0.161 & -0.061 \\
\hline & $(-30.724)$ & $(28.344)$ & $(-4.863)$ & $(-4.548)$ & $(-10.635)$ & (3.009) & $(16.022)$ & $(-4.399)$ \\
\hline \multirow[t]{2}{*}{ B5-S5 } & -0.271 & -0.442 & -1.219 & -0.622 & -0.952 & 0.438 & 0.299 & 0.386 \\
\hline & $(-14.296)$ & $(-18.715)$ & $(-52.594)$ & $(-24.222)$ & $(-39.213)$ & $(22.570)$ & $(11.552)$ & $(10.782)$ \\
\hline
\end{tabular}




\begin{tabular}{lllllllll}
\hline \multicolumn{2}{l}{ Emerging and developing } & economies \\
\hline S5-S1 & 0.254 & 0.547 & 0.877 & 0.961 & 1.044 & 0.023 & -0.589 & -0.322 \\
& $(12.281)$ & $(29.924)$ & $(37.315)$ & $(41.046)$ & $(45.577)$ & $(1.251)$ & $(-23.429)$ & $(-9.368)$ \\
B5-B1 & -0.462 & 0.271 & 0.127 & -0.084 & -0.084 & -0.132 & 0.175 & -0.045 \\
& $(-29.303)$ & $(22.851)$ & $(10.082)$ & $(-5.639)$ & $(-8.428)$ & $(-10.205)$ & $(18.731)$ & $(-3.401)$ \\
B5-S5 & -0.308 & -0.508 & -1.287 & -0.556 & -0.899 & 0.226 & 0.438 & 0.453 \\
& $(-17.658)$ & $(-23.772)$ & $(-57.071)$ & $(-24.063)$ & $(-42.095)$ & $(12.307)$ & $(17.722)$ & $(13.346)$ \\
\hline
\end{tabular}

$t$ statistics in parentheses

\section{Table 30. Price return reversals per portfolio}

This table reveals whether return reversals are present by different categories of sovereign bonds: all sovereign bonds, investment grade bonds, noninvestment grade bonds, sovereign bonds from advanced economies and sovereign bonds from emerging and developing economies. For each month, the buy and sell herding measures are divided in quintiles for the month in which pension funds buy or sell long-term sovereign bonds (in this case, at ar). The highest quintile (5) represents the most intensive buy or sell herding, whereas the lowest quintile (1) shows the least intensive buy or sell herding. The return consists of price changes. The returns are subtracted by the average monthly return. This calculation gives the $a r$ which is the abnormal return. Following Cai et al. (2012), we apply a portfolio strategy (e.g. S5-S1) which longs the S5 portfolio and shorts the S1 portfolio. This methodology is also applied for B5-B1 and B5-S5. The table shows whether the abnormal return on an investment portfolio basis is significantly different from zero for the two months prior to the buy or sell month $\left(a r_{t-2}\right.$ and $\left.a r_{t-1}\right)$, and for the five months after the buy or sell month $\left(a r_{t+1}, \ldots, a r_{t+5}\right)$. The $t$ statistics are in parentheses.

\begin{tabular}{|c|c|c|c|c|c|c|c|c|}
\hline Portfolio & $\boldsymbol{a r}_{t-2}$ & $a r_{t-1}$ & $a r$ & $a r_{t+1}$ & $a r_{t+2}$ & $\operatorname{ar}_{t+3}$ & $a r_{t+4}$ & $a r_{t+5}$ \\
\hline \multicolumn{9}{|l|}{ All bonds } \\
\hline \multirow[t]{2}{*}{ S5-S1 } & 0.222 & 0.182 & 0.206 & 0.627 & 0.644 & -0.097 & -0.566 & -0.883 \\
\hline & (13.543) & (12.195) & $(15.463)$ & $(40.712)$ & $(43.070)$ & $(-7.893)$ & $(-32.208)$ & $(-36.217)$ \\
\hline \multirow[t]{2}{*}{ B5-B1 } & -0.150 & 0.418 & 0.372 & -0.215 & 0.170 & 0.069 & 0.266 & -0.055 \\
\hline & $(-16.918)$ & $(52.489)$ & $(47.238)$ & $(-24.932)$ & $(27.793)$ & (7.134) & $(39.222)$ & $(-6.146)$ \\
\hline \multirow[t]{2}{*}{ B5-S5 } & -0.025 & -0.096 & -0.764 & -0.457 & -0.271 & 0.280 & 0.834 & 1.163 \\
\hline & $(-1.578)$ & $(-5.852)$ & $(-45.765)$ & $(-26.529)$ & $(-15.626)$ & $(18.878)$ & $(45.131)$ & $(47.154)$ \\
\hline \multicolumn{9}{|c|}{ Investment grade bonds } \\
\hline \multirow[t]{2}{*}{ S5-S1 } & 0.263 & 0.208 & 0.219 & 0.650 & 0.652 & -0.097 & -0.546 & -0.866 \\
\hline & (13.237) & (11.540) & $(13.722)$ & (34.397) & $(35.760)$ & $(-6.557)$ & $(-25.969)$ & $(-29.202)$ \\
\hline \multirow[t]{2}{*}{ B5-B 1} & -0.130 & 0.441 & 0.353 & -0.221 & 0.169 & 0.085 & 0.278 & -0.074 \\
\hline & $(-12.259)$ & $(45.881)$ & $(37.644)$ & $(-21.492)$ & $(23.011)$ & $(7.307)$ & $(34.045)$ & $(-6.880)$ \\
\hline \multirow[t]{2}{*}{ B5-S5 } & -0.049 & -0.118 & -0.809 & -0.492 & -0.288 & 0.286 & 0.817 & 1.144 \\
\hline & $(-2.511)$ & $(-5.945)$ & $(-39.896)$ & $(-23.408)$ & $(-13.615)$ & $(15.854)$ & $(36.688)$ & $(38.075)$ \\
\hline \multicolumn{9}{|c|}{ Noninvestment grade bonds } \\
\hline \multirow[t]{2}{*}{ S5-S1 } & 0.123 & 0.122 & 0.174 & 0.575 & 0.625 & -0.097 & -0.614 & -0.923 \\
\hline & $(4.283)$ & $(4.553)$ & (7.243) & $(21.810)$ & $(24.081)$ & $(-4.397)$ & $(-19.128)$ & $(-21.620)$ \\
\hline B5-B1 & -0.198 & 0.364 & 0.416 & -0.199 & 0.171 & 0.032 & 0.237 & -0.011 \\
\hline
\end{tabular}




\begin{tabular}{|c|c|c|c|c|c|c|c|c|}
\hline \multirow{3}{*}{ B5-S5 } & $(-12.206)$ & (25.637) & $(28.740)$ & $(-12.687)$ & (15.601) & (1.833) & (19.571) & $(-0.683)$ \\
\hline & 0.031 & -0.045 & -0.656 & -0.375 & -0.233 & 0.266 & 0.874 & 1.208 \\
\hline & (1.079) & $(-1.530)$ & $(-22.493)$ & $(-12.568)$ & $(-7.691)$ & $(10.256)$ & (26.396) & $(28.083)$ \\
\hline \multicolumn{9}{|c|}{ Advanced economies } \\
\hline \multirow[t]{2}{*}{ S5-S1 } & 0.298 & 0.237 & 0.233 & 0.684 & 0.669 & -0.088 & -0.516 & -0.815 \\
\hline & $(12.186)$ & $(10.811)$ & (11.993) & $(29.234)$ & $(29.666)$ & $(-4.912)$ & $(-20.500)$ & $(-22.973)$ \\
\hline \multirow[t]{2}{*}{ B5-B 1} & -0.111 & 0.481 & 0.332 & -0.224 & 0.169 & 0.110 & 0.297 & -0.091 \\
\hline & $(-8.728)$ & $(41.255)$ & $(29.629)$ & $(-17.967)$ & $(18.980)$ & $(7.777)$ & $(30.090)$ & $(-6.943)$ \\
\hline \multirow[t]{2}{*}{ B5-S5 } & -0.048 & -0.129 & -0.857 & -0.532 & -0.321 & 0.299 & 0.796 & 1.092 \\
\hline & $(-2.019)$ & $(-5.351)$ & $(-34.375)$ & $(-20.507)$ & $(-12.349)$ & $(13.452)$ & $(29.509)$ & $(30.155)$ \\
\hline \multicolumn{9}{|c|}{ Emerging and developing economies } \\
\hline \multirow[t]{2}{*}{ S5-S1 } & 0.148 & 0.129 & 0.180 & 0.574 & 0.620 & -0.105 & -0.613 & -0.946 \\
\hline & $(6.776)$ & $(6.355)$ & $(9.861)$ & $(28.367)$ & $(31.345)$ & $(-6.250)$ & $(-24.972)$ & $(-28.211)$ \\
\hline \multirow[t]{2}{*}{ B5-B 1} & -0.188 & 0.358 & 0.410 & -0.206 & 0.170 & 0.031 & 0.236 & -0.022 \\
\hline & $(-15.174)$ & $(32.895)$ & $(37.074)$ & $(-17.297)$ & $(20.327)$ & $(2.334)$ & $(25.403)$ & $(-1.766)$ \\
\hline \multirow[t]{2}{*}{ B5-S5 } & -0.003 & -0.064 & -0.674 & -0.386 & -0.224 & 0.262 & 0.870 & 1.229 \\
\hline & $(-0.151)$ & $(-2.874)$ & $(-30.261)$ & $(-16.909)$ & $(-9.683)$ & $(13.250)$ & $(34.312)$ & $(36.545)$ \\
\hline
\end{tabular}

$t$ statistics in parentheses 


\subsection{Data appendix}

\section{Table 31. Overview of data sources and calculations}

\begin{tabular}{|c|c|c|}
\hline Indicators & Unit & Sources \\
\hline Lagged logarithm of total holdings & Total holdings (x 1,000 euros) & De Nederlandsche Bank \\
\hline Lagged funding ratio & Ratio & De Nederlandsche Bank \\
\hline Lagged relative returns per sovereign & $\begin{array}{l}\text { County-pension fund returns minus total holdings } \\
\text { returns }\end{array}$ & De Nederlandsche Bank \\
\hline $\begin{array}{l}\text { Lagged relative performance fixed-interest } \\
\text { investments }\end{array}$ & $\begin{array}{l}\text { Fixed-interest investments returns minus total } \\
\text { holdings returns }\end{array}$ & De Nederlandsche Bank \\
\hline Lagged distance to the SAA & $\begin{array}{l}\text { Real sovereign bond allocation minus the strategic } \\
\text { sovereign bond allocation in absolute terms }\end{array}$ & De Nederlandsche Bank \\
\hline Lagged risk preference & $\begin{array}{l}\text { Strategic asset allocations in shares and private } \\
\text { equity over fixed-interest securities }\end{array}$ & De Nederlandsche Bank \\
\hline Lagged percentage of sovereign holding & $\begin{array}{l}\text { Average sovereign holding during the month over } \\
\text { total sovereign holdings at the pension fund level }\end{array}$ & De Nederlandsche Bank \\
\hline Inflation & Percentage change & OECD, World Bank, IMF \\
\hline Current account & Percentage of GDP & $\begin{array}{l}\text { OECD, De Nederlandsche } \\
\text { Bank, IMF }\end{array}$ \\
\hline Exchange rate, change & Percentage change & OECD, World Bank \\
\hline GDP growth & Percentage change & OECD, World Bank, IMF \\
\hline General government debt & Percentage of GDP & World Bank, IMF \\
\hline Logarithm of the sovereign bond market & Euros & World Bank \\
\hline Unemployment rate & Percentage of the labour force & OECD, World Bank, IMF \\
\hline Net government lending & Percentage of GDP & IMF \\
\hline Credit rating & $1 \mathrm{AAA}$ to $22 \mathrm{D}$ & Standard \& Poor's \\
\hline Credit outlook & -1 negative outlook to 1 positive outlook & Standard \& Poor's \\
\hline Stock market return & Percentage change & $\begin{array}{l}\text { OECD, De Nederlandsche } \\
\text { Bank, World Bank }\end{array}$ \\
\hline VIX index & Level of the VIX index & VIX index \\
\hline Yield & Level of the yield & Various central banks \\
\hline Long-term interest rate & Level of the long-term interest rate & OECD, IMF \\
\hline Logarithm of the CDS spread & Level of the CDS spread & De Nederlandsche Bank \\
\hline Credit rating change in the past 3 months & Change of the credit rating & Own calculation \\
\hline Credit outlook change in the past 3 months & Change of the outlook & Own calculation \\
\hline Control of corruption & -2.5 worst institutions to 2.5 best institutions & World Bank \\
\hline Government effectiveness & -2.5 worst institutions to 2.5 best institutions & World Bank \\
\hline $\begin{array}{l}\text { Political stability and absence of } \\
\text { violence/terrorism }\end{array}$ & -2.5 worst institutions to 2.5 best institutions & World Bank \\
\hline Regulatory quality & -2.5 worst institutions to 2.5 best institutions & World Bank \\
\hline Rule of law & -2.5 worst institutions to 2.5 best institutions & World Bank \\
\hline Voice and accountability & -2.5 worst institutions to 2.5 best institutions & World Bank \\
\hline
\end{tabular}


No. 542 Jasper de Jong, Marien Ferdinandusse and Josip Funda, Public capital in the 2Ist century: As productive as ever?

No. 543 Martijn Boermans and Sweder van Wijnbergen, Contingent convertible bonds: Who invests in European CoCos?

No. 544 Yakov Ben-Haim, Maria Demertzis and Jan Willem Van den End, Fundamental uncertainty and unconventional monetary policy: an info-gap approach

No. 545 Thorsten Beck and Steven Poelhekke, Follow the money: Does the financial sector intermediate natural resource windfalls?

No. 546 Lola Hernandez, Robbert-Jan 't Hoen and Juanita Raat, Survey shortcuts? Evidence from a payment diary survey

No. 547 Gosse Alserda, Jaap Bikker and Fieke van der Lecq, X-efficiency and economies of scale in pension fund administration and investment

No. 548 Ryan van Lamoen, Simona Mattheussens, and Martijn Dröes, Quantitative easing and exuberance in government bond markets: Evidence from the ECB's expanded asset purchase program

No. 549 David-Jan Jansen and Matthias Neuenkirch, News consumption, political preferences, and accurate views on inflation

No. 550 Maaike Diepstraten and Carin van der Cruijsen, To stay or go? Consumer bank switching behaviour after government interventions

No. 55I Dimitris Christelis, Dimitris Georgarakos, Tullio Jappelli, Luigi Pistaferri and Maarten van Rooij, Asymmetric consumption effects of transitory income shocks

No. 552 Dirk Gerritsen, Jacob Bikker and Mike Brandsen, Bank switching and deposit rates: Evidence for crisis and non-crisis years

No. 553 Svetlana Borovkova, Evgeny Garmaev, Philip Lammers and Jordi Rustige, SenSR: A sentimentbased systemic risk indicator

No. 554 Martijn Boermans and Rients Galema, Pension funds' carbon footprint and investment trade-offs

No. 555 Dirk Broeders, Kristy Jansen and Bas Werker, Pension fund's illiquid assets allocation under liquidity and capital constraints

No. 556 Dennis Bonam and Gavin Goy, Home biased expectations and macroeconomic imbalances in a monetary union

No. 557 Ron Berndsen and Ronald Heijmans, Risk indicators for financial market infrastructure: from high frequency transaction data to a traffic light signal

No. $55^{8}$ Monique Timmermans, Ronald Heijmans and Hennie Daniels, Cyclical patterns in risk indicators based on financial market infrastructure transaction data

No. 559 Dirk Bezemer, Anna Samarina and Lu Zhang, The shift in bank credit allocation: new data and new findings

No. 560 Jacob Bikker and Tobias Vervliet, Bank profitability and risk-taking under low interest rates

No. 56I Dirk Broeders, Arco van Oord and David Rijsbergen, Does it pay to pay performance fees? Empirical evidence from Dutch pension funds

No. 562 Nikki Panjer, Leo de Haan and Jan Jacobs, Is fiscal policy in the euro area Ricardian?

No. 563 Carin van der Cruijsen, Payments data: do consumers want to keep them in a safe or turn them into gold?

No. 564 Gabriele Galati and Federica Teppa, Heterogeneity in house price dynamics

No. 565 Dennis Bonam, Jakob de Haan and Beau Soederhuizen, The effects of fiscal policy at the effective lower bound

No. 566 William Allen, Gabriele Galati, Richhild Moessner and William Nelson, Central bank swap lines and CIP deviations

No. 567 Jan Willem van den End, Applying complexity theory to interest rates: Evidence of critical transitions in the euro area

No. 568 Emiel van Bezooijen and Jacob Bikker, Financial structure and macroeconomic volatility: a panel data analysis 
De Nederlandsche Bank N.V.

DeNederlandscheBank

Postbus 98, 1000 AB Amsterdam

O2O 5249111

dnb.nl 